\title{
SAND78-7010 \\ GEOTHERMAL WELL COMPLETIONS \\ An overview of existing methods \\ in four types of developments
}

BY: ROBERT E. SNYDER

\section{CONTENTS}

INTRODUCTION

STATUS, POTENTIAL OF FOUR CATEGORIES

COMMON REQUIREMENTS AFFECTING COMPLETION DESIGN

THE GEYSERS

IMPERIAL VALLEY

HOT, DRY ROCKS

GULF COAST GEOPRESSURED GEOTHERMAL ZONE

Work performed under Sandia Contract 05-6199 sponsored by U. S. Department of Energy, Division of Geothemal Energy. Published January, 1978

\section{Sandia Laboratories}

\author{
9506922 \\ G T C COMPLETION TECHNOLOGY COMPANY \\ 4200 WESTHEIMER RD., SUITE 211 - HOUSTON, TEXAS 77027 \\ 713/961-5011 - TELEX: 775781




\section{GEOTHERMAL WELL COMPLETIONS}

An overview of existing methods

in four types of developments

BY: Robert E. Snyder

Page

Table of Contents

List of Figures and Tables _ _ _ _ il

$$
\begin{aligned}
& \text { This report was prepared an account of work } \\
& \text { sponsored by the United States Covemment. Neither the } \\
& \text { United States nor the United States Department of } \\
& \text { Energy, nor any of their employees, nor any of their } \\
& \text { contractors, mubcontractors, of their employees, makes } \\
& \text { any warranty, express or implied, or assumes any legal } \\
& \text { liability or responsibility for the sccurncy, completeness } \\
& \alpha \text { usefulness of any information, apparatus, product or } \\
& \text { process disclosed, or represents that its use would not } \\
& \text { infringe privately owrned rights. }
\end{aligned}
$$

This report was prepared as annaccount of work sponsored by the United States Government. Neither the United States nor the Department of Energy, Division of Geothermal Energy, nor any of their employees, nor any of their contractors, subcontractors, or their employees, makes any warranty, express or implied, or assumes any legal liability or responsibility for the accuracy, completeness or usefuliness of any information, apparatus, products or process disclosed, or represents that its use would not infringe privately owned rights. 
TABLE OF CONTENTS

Page

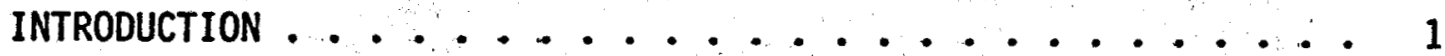

Scope, Objectives , . . . . . . . . 1

Definitions of Wel1 Completions $4 . . . . .4$

Organizational Constraints on Technology Development : 5

STATUS, POTENTIAL OF FOUR CATEGORIES . . . . . . . . . 7

Vapor Dominated Systems ............. 7

Low Pressure Hot Water Reservoirs . . . . . . . 8

Geopressured Geothermal Zone, Dry Rock . . . . . . 9

COMMON REQUIREMENTS AFFECTING COMPLETION DESIGN ...... . 11

THE GEYSERS ...................... 13

High Energy Product _. . . . . . . . . . . 13

Reservoir, Fluid Properties ........... 13

Corrosion, Water Disposa] ......... 17

Drilling Problems, Specia1 BOP Stacks . . . . . . 20

Foam Drilling Systems _ _ _ _ . . . . . 24

Difficult Locations, Directional Drilling . . . . . 24

Moving Off the Rig $+\ldots,+\ldots+\cdots, \ldots \ldots 26$

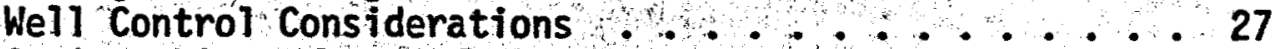

Casing, Liner, Open Hole Program _........ 30

Casing Design, Installation Factors . . . . . . 32

Thermal Stress on Casing. Thread Selection . . . . . 34

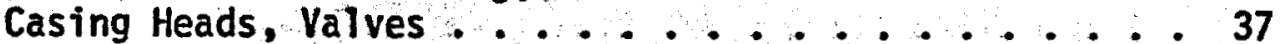

Expanding Wellheads _............ 40

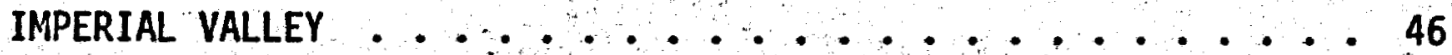

Development Status _. _ . . . . . 46

Comparison with the Geysers : . . . . . . . 48

Reservoir, Fluid Properties .......... 49

Flowing Mechanism, Downhole F\}ashing Problems . . 53

Productivity Index, Downhole Pumps . . . . . 56

Formation Stress Factors, Perforating vs. Slotted Liners 60

Completion Methods, Casing-Liner Programs ...... 62

Mud, Cement .................... 68

Sand Control, Non-Damaging Fluid Application . . . 68

Fluid Handling Systems, Injection Problems . . . . 71 
HOT, DRY ROCKS ................................ 73

Definitions, Project Background ......... 74

Marysville, Montana, Project _........ . 75

Val les Caldera Project Goals, Progress . . . . . . 76

Djscussion of Operations .............. 80

Project Conclusions, Recommendations ...... 85

GULF COAST GEOPRESSURED GEOTHERMAL ZONE ......... 88

Introduction, Program Status .......... 88

Edna Delcambre 1 Well Test Summary . . . . ..... 90

Brazoria County Test: Goals, Completion Program ... 92

Geopressures: Definition, Discussion ....... 94

Produced Flujds: Water Properties, Methane . ... 102

Resource Description, Net Energy . . . .... 103

Pressure Control, Casing-Liner Programs . . ... 108

Sand Production, Control Problems ......... 110

Completion Design Considerations .......... 112 


\section{LIST OF FIGURES AND TABLES}

Page

Fig. 1. Map of four U.S. geothermal projects .........2

Fig. 2... Drill pipe damage at The Geysers . .......... . 14

Fig. 3. The Geysers downhole geothermal mechanism . . . . . 16

Fig. 4. Power plant schematic at The Geysers . . . . . . . 19

Fig. 5. BOP stack for mud drilling ............ 21

Fig. 6. BOP stack with Banjo Box............... 22

Fig. 7. Map of surface elevations at The Geysers _...... 25

Fig. 8. Completed geothermal wells ............. 28

Fig. 9. Typical casing program at The Geysers .... . . . . 31

Fig. 10. Comparison of API threads and premium joints ..... . 35

Fig. 11. Potential casing problems in geothermal wells . . . . 38

Fig. 12. Casing head on simple geothermal completion ...... 39

Fig. 13. Geothermal valve with expanding gate . . . . . . . 41

Fig. 14. Expanding wellhead wi th stationary seal ......443

Fig. 15. Expansion spool with seal on casing stub ....... 44

Fig. 16. Map of Imperial Valley projects . . . . . . . 47

Fig. 37. Schematic of non-flashing flow system .......58

Fig. 18. Proposed Sperry Rand geothermal pump . ....... . 59

Fig. 19. Proposed Sunstrand geotherma1 pump ........61

Fig. 20 Pack Perf Completion System schematic ........63

Fig. 21. Imperial Valley casing programs ...........65

Fig. 22. Schematic of wash tool operation .......... 66

Fig. 23. Cross section of Valles Caldera geology ....... 77

Fig. 24. Hot, dry rocks heat recovery concept . . . . . . 79

Fig. 25. Type rock, temperature in Valles Caldera wells .... . 81 
Fig. 26. Casing programs for dry rocks test wells $6.6 \ldots \ldots \ldots 4$

Fig. 27. Preliminary Brazoria test well casing program .... 95

Fig. 28. High pressure wellhead for multiple casing ...... 96

Fig. 29. Geologic cross section of U.S. Gulf Coast ...... . 97

Fig. 30. Porosity behavior in geopressured zones ....... 100

Fig. 31. Detection methods in transition zones ....... 100

Fig. 32. Expanded methane solubility curves . . . . . . . 104

Fig. 33. Injection well performance vs, tubing size . . . . 107

Fig. 34. Formation, mud pressure gradient concepts ...... 109

Fig. 35. Producing well performance vs. tubing size ... . . 114

Table 1. Analysis of unflashed East Mesa brines ........ 52

Table 2. Reservoir fluid composition from two Salton Sea geothermal wells ................. 54

Table 3. Corrosion data from bottom hole samples in Salton Sea geothermal wells ............. 54 


\section{INTRODUCTION}

This report will discuss existing practices and capabilities for completing producing and injection wells for geothermal application in each of four categories of geothermal environments:

1. Steam wells in hard, fractured rocks (The Geysers, California)

2. Hot water wells in sedimentary formations (Imperial Valley, (alifornia)

3. Hot, dry impermeable rocks with circulating water systems (Valles Caldera; New Mexico), and

4. Geopressured, geothermal water wells with associated hydrocarbon production on the U.S. Gulf Coast.

\section{Scope, Objectives.}

The specific Tocations noted are discussed because conditions are reasonably representative of the four geothermal categories selected, Figure 1. Many other geothermal projects are proposed, or in field test stages in the United States. And several producing areas exist in other countries utilizing relevant completion practices. However, interpretation of international operations is beyond the scope of this report.

The objective is to illustrate basic concepts and requirements, the stateof-the-art, by describing geothermal completions as a transition from conventional oil and gas industry technology. This is accomplished by establishing significant differences in the two technologies with a detailed 


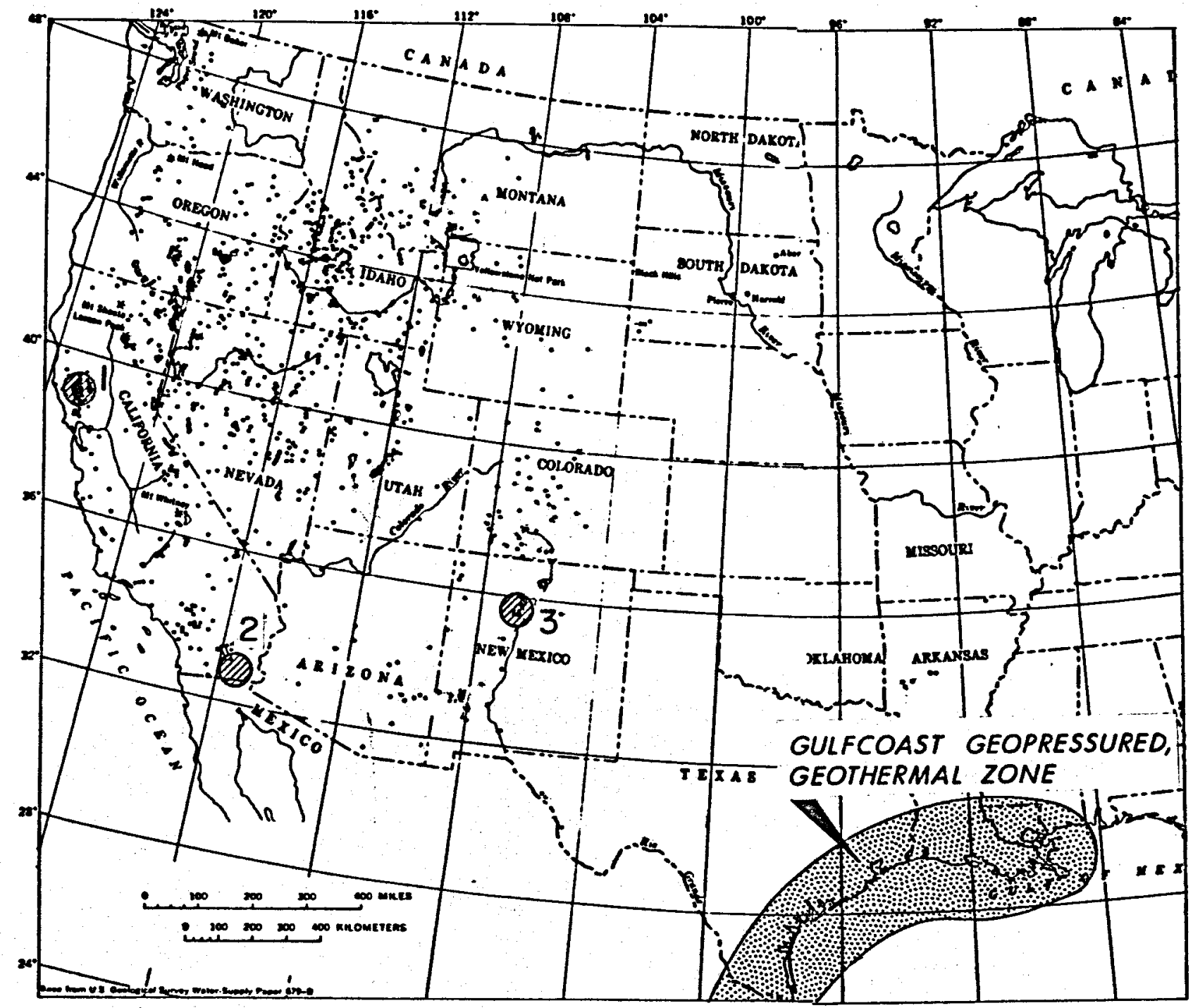

10 JHE GEYSERS DRY STEAM PRODUCTION

20 IMPERIAL VALLEY HOT WATER BASIN

3 Valles CALDERA hOt dRY ROCKS PROJECt AND STEAM WELlS

- thermal springs

GEOTHERMAL PROJECTS DISCUSSED IN THIS REPORT. THERMAL SPRING LOCATIONS INDICATE GENERAL AREAS OF INTEREST IN WESTERN STATES. 
look at The Geysers. Special applications for various geothermal conditions then are emphasized by comparing one project with another.

This report is intended te be critical and objective. The hypothesis is--if a power plant were suddenly approved and placed on location, could industry immediately start a drilling and completion program with near $100 \%$ assurance of supplying adequate hot water or steam, with reasonabiy safe, trouble-free operations. There are too many unsolved operational problems in some proposed projects to permit them to pass this "acid test". And, for private industry development, economics is the key factor.

But there are two conditions under which major geothermal projects can be developed: 1) A private enterprise can invest money, develop on its own and attempt to make a reasonable profit, or 2) The U.S. Government can create the economic incentive so that a private enterprise can operate at a profit, and the U.S. taxpayers will pay for the incremental difference between geothermal energy and conventional energy.

In a strict and objective analysis; many geothermal projects would not be viable under the first condition, and this is a significant factor in the state-of-the-art. of course this state-of-the-art can and will change rapidly, perhaps just from the simple process of having a problem brought to someone's attention. So certain conclusions may not be valid within a few months.

The second condition could be an extremely desireable course of action for the Nation. Paying the equivalent of say $\$ 20$ per barrel of oil for geothermal power and thereby creating local jobs, and circulating the money within the U.S., would be significantly more beneficial than sending \$12-15 per barrel out of our country to buy foreign crude. By releasing the typical industry constraint of "Can we afford it?", most geothermal projects discussed herein have attractive potential. 
Definitions of Well Completions

A geothermal environment is considered to be one in which the objective is to produce and sell heat, utilizing water or steam as a means of "mining" this heat from deeply buried locations.

Well completion is the phase of development that follows the drilling operations. It includes prevention of impairment to the production interval, design and installation of casings and liners, removal of fluid and/or drilling mud damage from the formation face, perforating or otherwise opening of the formation to the wellbore, and installation of wellhead and flowline equipment to handle produced fluids between the formation and surface processing facilities. It also includes the same operations needed to prepare an injection well to accept large volumes of water.

Methods used in drilling the borehole to, and through, the producing formations are important to the completion phase. The physical condition of the resulting borehole, i.e. presence of washed out sections, drilling fluid penetration into the potentially productive formation, presence of junk or excessive cuttings, etc., has a significant effect on the success of casing installation and its performance in future life. And the ability of the formation to produce high volumes of water--or accept high volumes, in the case of injection wells--may be greatly reduced.

Thus, operations of interest to the completion engineer overlap the final portion of drilling operations as well as early phases of production. For example, even before the drilling rig is removed, flow rate may be tested for desired volume, and potential problems such as sand production or productivity impairment may be recognized and corrected by stimulations or remedial work. This could include hydraulic fracturing, acidizing, sand screen installation, additional perforating and cement squeezing. 
Later in well life, similar remedial operations may also be required. Such operations are loosely classified as workovers and are commonly evaluated and supervised by the operator's production engineering staff. Geothermal wells present special problems that limit workover success, as will be explained.

\section{Organizational Constraints on Technology Development}

Any organization or private company should realize that effective well completion is critical to successful geothermal development. It is fairly common for oil companies to eliminate the completion engineer and make the drilling department responsible for much of the above described completion operations. Thus many drilling departments control important features in completion design, placing important long term decisions in the hands of those with other primary responsibilities, i.e. the boring and casing of a hole in the ground at minimum cost. This undesirable situation is an often criticized peculiarity of the oil and gas industry.

Add this type of organization to the fact that most geothermal operations are being conducted in very remote locations, where the valuable technical contributions and facilities of experienced service companies are limited, and the situation becomes a significant factor in the ability of industry to apply new completion technology to geothermal development.

An example of this problem is the recent experience of a major oil company in drilling and completing a geothermal exploratory well in the Nevada mountains in mid-winter. In this project, the field engineer attempted to work on location with a non-winterized rig, to evaluate a new drilling-completion fluid. Inappropriate instrumentation, leaking equipment 
seals and a poorly defined program due to lack of involvement in early planning stages caused results to be inconclusive, and a learning opportunity was missed.

Other factors retarding geothermal technology development are:

1. Proprietary interests of various private groups. This promotes duplication and preventswide dissemination and subsequent improvement of completion technology.

2. Limited interest by major oil companies in committing research and engineering effort to geothermal, from a purely economic standpoint.

3. Excessive governmental red tape in leasing land.

4. Delays in power plant approval for projects which require heavy front end investment and accurate cash flow scheduling. This slows the evolutionary technology development process in which innovations come rapidly by trial and error.

5. Overemphasis of environmental and legal considerations without parallel programs for practical technology development.

As a result, programs to improve pioneering efforts in geothermal well completions have not been given high priorities. Hopefully, government sponsored research and a National commitment to alternate energy development can accelerate the learning process.

The Department of Energy's geothermal program could be set back by a serious accident in a major project, if adverse public opinion results. Thus, best available well control features should be specified in operations involving hot, potentially damaging brines in environmentally sensitive areas. Special precautions should be taken in Gulf Coast geopressured geothermal zone operations. 


\section{STATUS, POTENTIAL OF FOUR CATEGORIES}

Considering the four categories of geothermal development (steam, hot water, dry rocks and geopressure) from the stand point of converting the basic heat resource into commercial production under the previously described economic conditions faced by private industry, these evaluations are offered:

\section{Vapor Dominated Systems}

Dry steam production from hard, fractured rocks similar to those in The Geysers can be handled by industry at the present time, as proved by successful operation of the California project. The production of energy in the form of a $500^{\circ} \mathrm{F}$, dry, non-corrosive vapor permits installation of simple completion equipment between wellbore and plant. Dense, hard rocks produce small volumes of abrasive sand and other particulates; after they. stabilize, to minimize operating problems.

Stimulation, acidizing, and cementing are not required, as zones are completed in open hole after suitable productivity has been exposed. Reinjection problems are minimized by small concentrations of scaling products in the cool, condensed water by-product, and the common practice of evaporating part of the plant effluent, Bottom hole pressures are low (500 psi) permitting great flexibility and economy in equipment design. Corrosion is most severe in the condensate handling system. Typical Geysers completion practices are described later in this report.

Major constraints are the lack of prospects for this desirable resource, slow leasing on federal lands and power plant approval delays. 
Low Pressure Hot Water Reservoirs

High volume, hot water sources in shallow sedimentary rocks typical of the Imperial Valley of California, cannot be considered commercial because no plants have been installed to purchase the heat. However, exploration, drilling and testing are progressing rapidly, and industry is much closer to installation of a commercial, electricity generating plant than most casual observers believe. If such a plant were installed now, at least one operator has sufficient test data to proceed with field development.

Imperial Valley operations have been given a bad name by reports on years of activity in which hot mineral water was flowed into ponds or other surface systems for a variety of reasons-commercial salt recovery, heat resource evaluations, etc. The result of this flashing and cooling was inevitable rapid and extremely heavy scale build-up and severe corrosion from oxygen entrainment.

Scale buildup and corrosion are major problems but they are not consistent throughout the area. Total dissolved solids (TDS) vary from concentrations of less than $2,000 \mathrm{ppm}$ in southern areas to over 300,000 ppm near the Salton Sea. Some operators believe scaling problems in low TDS areas will be minimal, perhaps no worse than those now being handled routinely in existing refinery heat exchangers, if system pressures can be maintained.

Imperial Valley geothermal reservoirs are underpressured, with bottom hole pressures (BHP) slightly below hydrostatic. But where reservoir temperature is high enough, density reduction of the flowing hot water column may be sufficient to give very high flow rates, up to 100,000 bpd per well. And to keep flowing pressures above the flash point (250 psi for $400^{\circ} \mathrm{F}$ pure water) submerged centrifugal pumps operating in enlarged 
casing sections can supplement natural flow. These various systems and related completion designs will be discussed later in this report

Geopressured Geothermal Zone, Dry Rocks

Government, industry and various universities are actively pursuing evaluation and testing in two new geothermal categories: 1) Energy in deeply buried, very high pressure sands of the U.S. Gulf Coast to be derived from heat, pressure and methane gas, all contained in the same high. volume water flow, and 2) Widespread buried heat to be extracted from "dry" rocks by circulating water from well to well.

The commercial potential of both projects, for private development, is not very attractive at this time. And it appears that major problems also must be solved in drilling and completion phases before economical, trouble free, multiwell programs can be initiated. Government funds will be well placed in research programs aimed at improving geopressured and dry rock drilling, completion and injection technology.

Many questions about geopressured hot water will be answered as tests proceed in Brazoria County, Texas, in the first grass roots geopressured, geothermal test well, and in six "wells of opportunity" to be tested by Gruy Federal of Houston. Some operational problems have already been evaluated in the Edna Delcambre 1 test in South Louisiana.

Despite high costs and potential problems, there are attractive possibilities. Water flow of 40,000 bpd or more will contain at least moderate heat energy, with temperatures ranging from $250^{\circ}-450^{\circ} \mathrm{F}$. And methane gas concentrations of over 20 cubic feet per barrel will give one immediately marketable product. A more detailed discussion of geopressure behavior and completion design consideration will be presented later in this report. 
In pursuit of heat contained in hot, dry rocks, Los Alamos Scientific Laboratories is actively testing two wells drilled through solid granite at the Valles Caldera, New Mexico site. The wells will evaluate the concept of creating an in situ heat exchanger by hydraulically fracturing the granite to develop a large interconnecting surface area.

Dry rock that is impermeable enough to allow circulation with minor water loss was found at 10,000 feet in rock temperatures of $387^{\circ} \mathrm{F}$. Conventional and directional drilling operations were halted frequently for many scientific tests, and advanced acoustic and seismic methods for defining hydraulic fracture orientation were evaluated.

Many off the shelf oil industry tools were utilized in the tests and valuable insight is being gained into equipment limitations in hot, volcanic rocks. However, followup improvements will likely be slow unless the equipment has other commercial applications. Valles Caldera operations and project conclusions, and other related dry rocks investigations, are described later in this report. 


\section{COMMON REQUIREMENTS AFFECTING COMPLETION DESIGN}

Several requirements are common to all types of geothermal developments and greatly influence completion design, for example:

1. A power plant is necessary for complete project development and wells must be located close (within \pm one mile) to the plant to prevent heat and pressure loss. Thus, wells must be completed in groups and this situation lends itself to pad type development in which several directional wells are drilled from one location. Such a scheme is planned for the Imperial Valley. It is more difficult in the Geysers due to mountainous surface terrain and directional drilling problems.

2. The complete flow system from formation face into the wellbore and through casing, wellhead and flowline must be sized to correctly handle the fluid. Maximum line sizes with minimum friction are needed to retain heat energy and prevent pressure loss that will start scale precipitation or steam condensation.

3. Water injection systems must be developed in conjunction with all production schemes. Brine disposal will be required projects for environmental reasons. And in long life projects, reinjection will be a key part of the system, to recharge the subterranean water supply. In the Cerro Prieto project in northern Mexico, hot water effluent reportedly is not reinjected, thereby eliminating one major consideration that U.S. developers must resolve.

4. Equipment will be exposed to long term effects of high temperature, aqueous systems and relatively dirty fluids. Common problems that result are: Casing, liner, tubing and flowline elongation and 
contraction; deterioration of elastomer seals; cement strength retrogression; and plugging of valve, sliding sleeve and orifice recesses.

5. Scaling and corrosion will be common and persistent problems as the product in all cases will be water (except in rare dry steam wells) containing high concentrations of salts and other dissolved solids. Hydrogen sulfide is present in minor amounts in most geothermal systems and contributes to corrosion problems in The Geysers and in the Imperial Valley; it is reportedly minimal in the Gulf Coast geopressured zone. This would be fortunate as high strength, high carbon steel tubulars will be needed for pressure control. 


\section{THE GEYSERS}

High Energy Product

The combination of competent rocks, low reservoir pressures and a dry steam product allows operators to complete wells relatively simply. The object is to provide a wide open bore for maximum steam flow from formation to surface and the low pressures allow use of large diameter tubulars. However, the energy contained in the $500^{\circ} \mathrm{F}$ steam, while not difficult to contain, can be potentially destructive or hazardous if released improperly. In an oil or gas product, the energy is latent and must be released by combustion; in steam, it is already there.

In one early Geysers well, before diverters and mufflers were used for flow testing and cleaning new wells, the steam from the blooie line of a new well reportedly blew down two eight inch thick oak trees at a considerable distance from the location. Confined in a restricted annular space, such as between drill pipe and the wellbore, such a stream becomes a jet with velocity approaching the speed of sound; and with the addition of sharp, angular formation sand and larger rock particles found in The Geysers formations, the damaging potential is extremely high. Tool joint shoulder wear on drill pipe in wells drilled-in with air is the most common example of the steam's destructive capability, Figure 2. Up to $50 \%$ of a string can be ruined in one well.

\section{Reservoir, Fluid Properties}

Geysers "reservoirs" are not typical oil field types. The rocks are classified as metamorphosed sedimentary, primarily graywacke, which consists of sharp silica grains in a dark, dense, well cemented martix. 


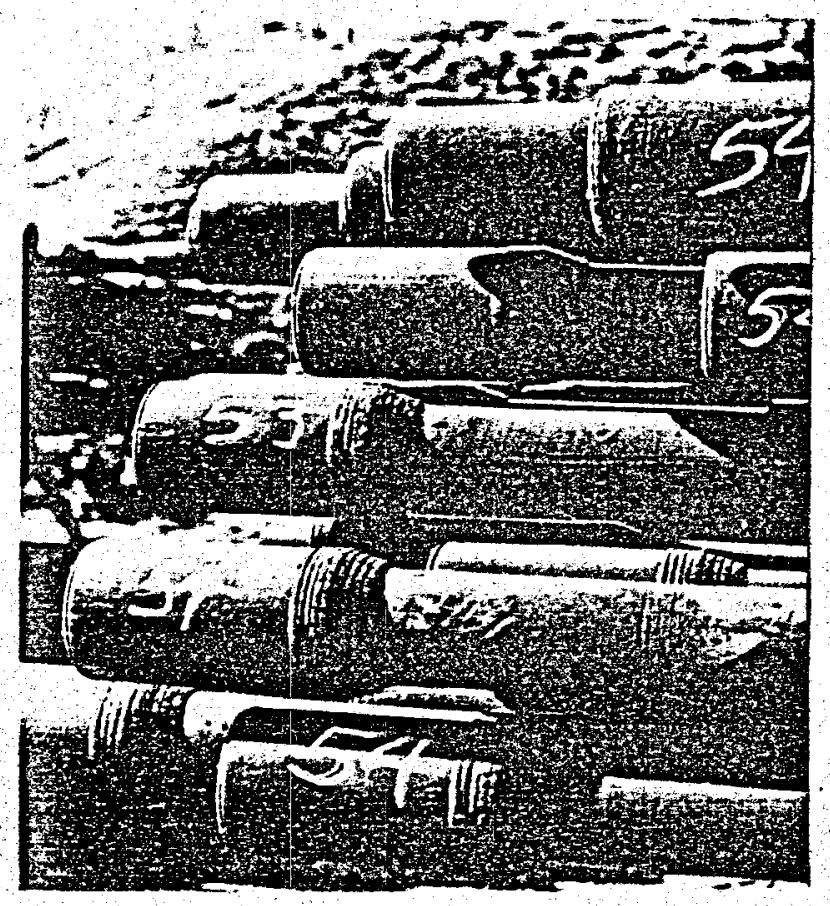

RECONDITIONED DRILL PIPE

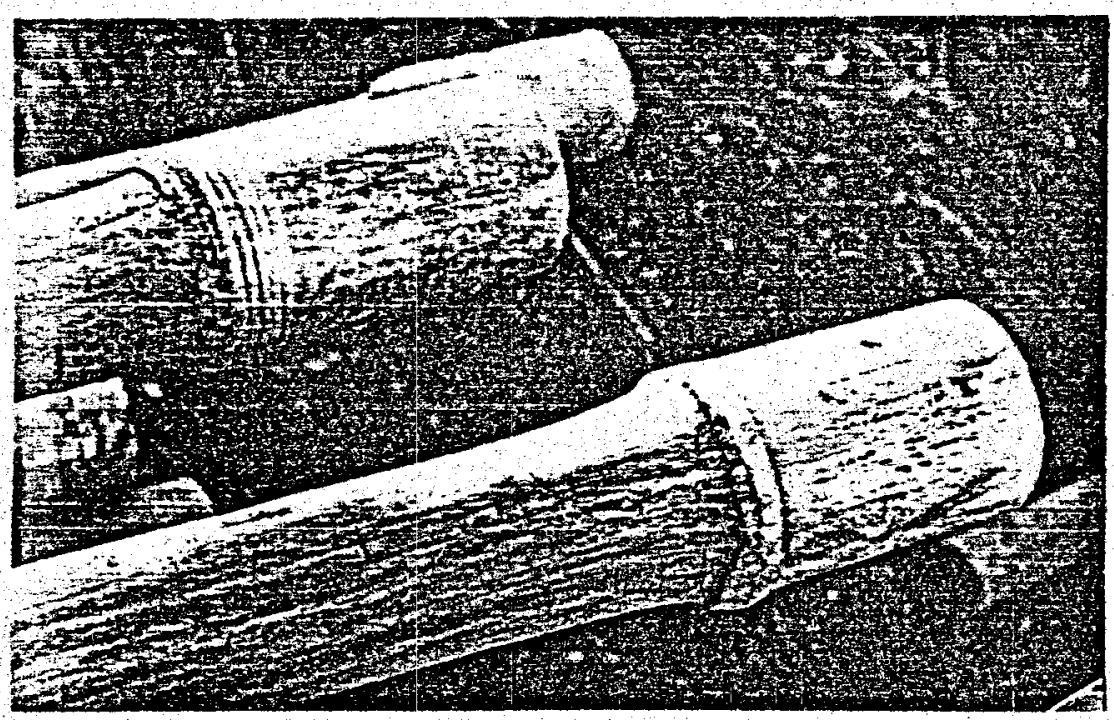

SEVERELY ERODED TOOL JOINTS

DRY STEAM AND AIR CONTAINING ROCK PARTICLE SEVERELY DAMAGE ORILL PIPE IN THE GEYSERS AS SHOWN BY PHOTOS OF TOOL JOIN EROSION. WELLHEADS AND VALVES HAVE SPECIAL TRIM TO MINIMIZE EROSION DAMAGE. Photographs Courtesy World 0il. 
Stringers of serpentine and chert are prevalent above the steam zone. A reservoir is created when the formation at a particular well site contains enough natural fractures to transmit entrapped superheated water at lower depth upward to a point where pressure loss allows the water to flash. In The Geysers, the steam is dry with a few degrees of superheat. Fractures to surface have been sealed by silica deposits from earlier condensations and depositions, so the steam cannot escape, Figure 3.

Because there is insufficient water supply to the fractured-rock heating system to flood it, reservoir pressure is not a function of hydrostatic head. Thus, 7,000 foot Geysers wells have bottom hole pressures in the range of $450-500 \mathrm{psi}$, instead of $3,000 \mathrm{psi}(7,000$ feet $\times .434 \mathrm{psi} / \mathrm{pf})$. Conditions differ greatly from location to location, and each well must be considered a "wildcat" as far as steam volume, location and thickness of productive fractured zones is concerned.

Reservoir pressures of 450-500 psi are reduced to about 125 psi at the wellhead by expansion and cooling in the casing. Reservoir temperatures are typically less than $500^{\circ} \mathrm{F}$, and corresponding wellhead temperatures would be about $370^{\circ} \mathrm{F}$ if the product had a superheat condition of less than $20^{\circ} \mathrm{F}$. The typical product delivered to the turbine inlet at the generating plant is $355^{\circ} \mathrm{F}, 114$ psi dry steam.

Production is measured in pounds per hour of dry, superheated steam. A very good Geysers wel1 would produce $300,000-400,000$ pph. Operators look for 150,000-200,000 pph. Plants now being installed require about 2 million pph and would need the combined production of 14-16 typical wells. 


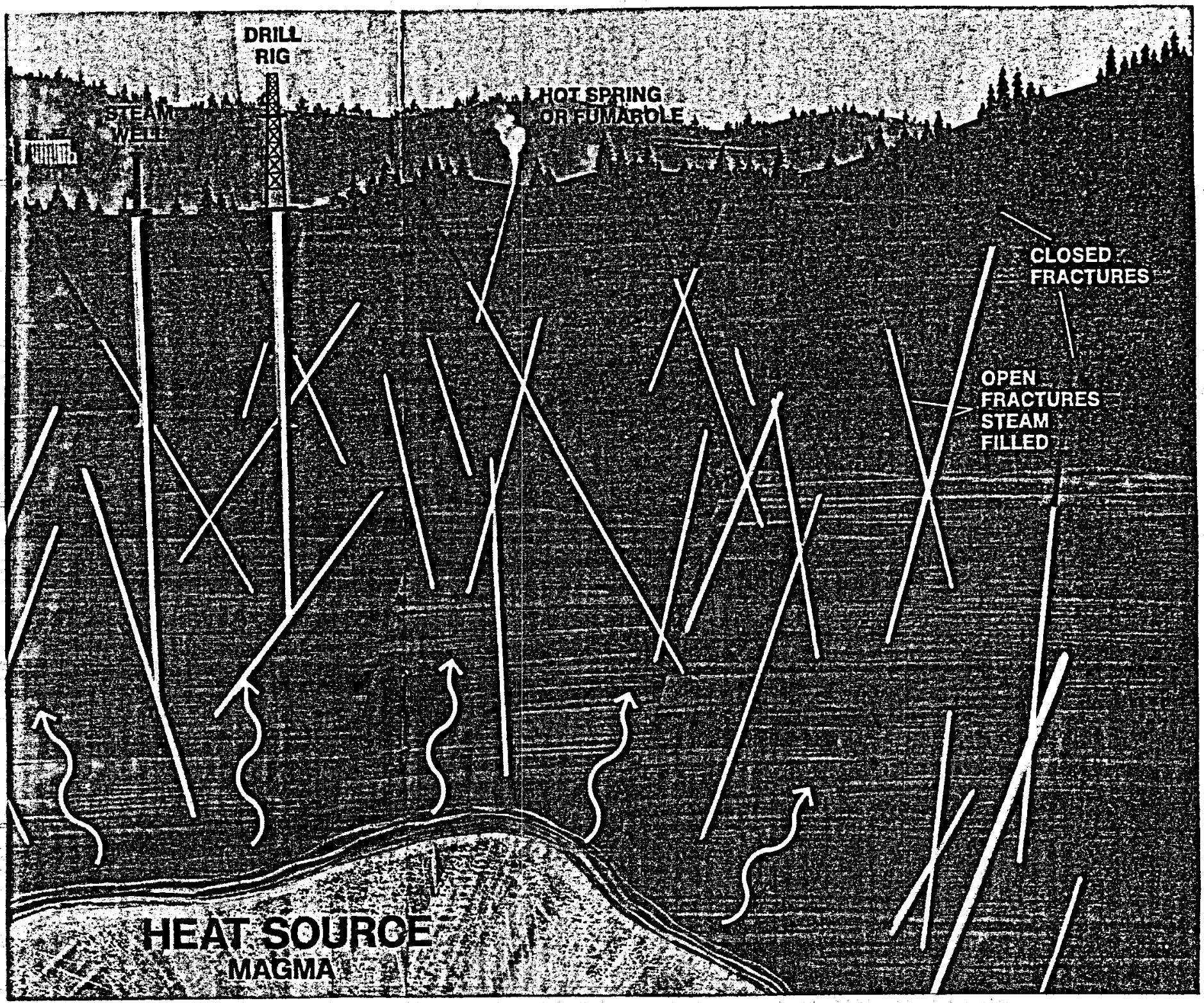

Courtesy Union 011 Co.

SCHEMATIC OF THE GEYSERS GEOTHERMAL MECHANISM SHOWS HOW OPEN FRACTURES ALLOW LIMITED WATER FLOW DOWN TO HOTTER ROCKS AND HOW SUPERHEATED STEAM IS CONTAINED BY SEALED FRACTURES NEAR SURFACE. 
Corrosion, Water Disposal

The formation steam is dry and essentially non-corrosive, so carbon steel completion systems can be used upstream of the plants, with special provisons for erosion protection such as special valve and wellhead trim.

After this steam gives up its heat as energy to turn turbine blades, it condenses and contacts air. The resulting product is hot water containing oxygen, which partially oxidizes the small concentration of hydrogen sulfide into weak sulfuric acid that is highly corrosive.

Carbon steel, copper based alloys, zinc and cadmium are unsuitable for handling this corrosive effluent. Austenitic stainless steel, aluminum and epoxy-fiber glass products are used.

Hydrogen sulfide in the air, liberated from vent stacks drawing off non-condensable gases from the turbine discharge, and from the huge water evaporator-coolers, is noticeable by its odor. While it is no significant health hazard in such small concentrations, it will corrode exposed bare carbon steel such as wear-polished drill pipe, and, of course, copper or silver electrical wiring and contracts.

Steam from the wells contains about $1.0 \%$ non-condensable gases in the following concentrations:

0.79

Ammonia .07

Methane .05

Hydrogen sulfide

.05

Nitrogen and Argon

.03

Hydrogen

.01

Total

$1.00 \%$ 
Effluent volume is reduced by $80 \%$ in large wooden baffle cooling towers which take $120^{\circ} \mathrm{F}$ water from turbine condenser sections and return it at $80^{\circ} \mathrm{F}$ to cool steam exiting from the turbine blades, Figure 4.

Thus, the liquid effluent volume is reduced to $20 \%$ of the produced amount. Primarily, this water is reinjected into the reservoir as a disposal project. The long range benefit on reserves of reinjecting cold water to recharge the subterranean supply systems have not been assessed. It is known from experience that too much injection close to a producer can flood the fracture system and kill the well.

Chasteen (1975) noted that 112,000 bpd was being injected into six Geysers wells from 522 MW of installed capacity. The condensed steam is essentially fresh water but small volumes of ammonia and boron contaminates are above limits set for surface discharge. From the cooling towers, the water flows through concrete settling basins $50 \mathrm{ft} \times 50 \mathrm{ft}$ by $8 \mathrm{ft}$ deep with wooden baffles to collect settleable solids. Air is prevented from entering lines to the wells to minimize $0_{2}$ corrosion. Injection wells require slotted liners to prevent formation sloughing from water contact. Wells are cased with full length $95 / 8$ inch casing.

The highly fractured nature of the rock should allow deep injection of large volumes of small particulates before injectivity impairment becomes excessive. Chasteen notes $\mathrm{md} f \mathrm{ft}$ values of $20,000-150,000$, which allow 40,000 bpd injection with no wellhead pressure. Occasionally, elemental sulfur is deposited on the fracture faces and wells are shut in to allow formation heat to melt the deposits. Injection is supervised closely by the California Division of $0 i 1$ and Gas. 


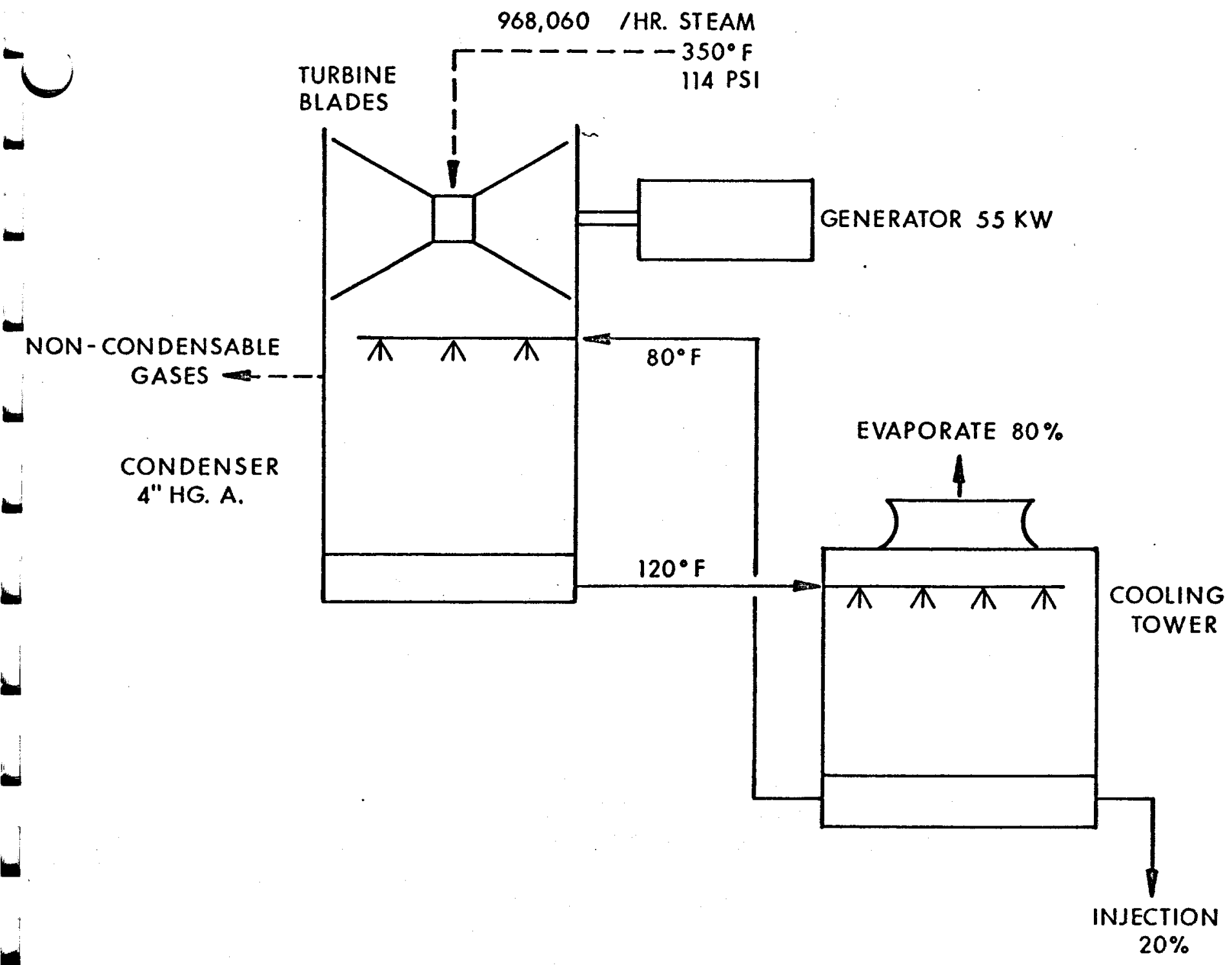

Courtesy World 0 il

GEYSERS POWER PLANT SCHEMATIC SHOWS FLOW OF DRY STEAM THROUGH TURBINE INTO CONDENSER AND COOLING TOWER. PART OF STEAM IS DIVERTED THROUGH EJECTORS TO MAINTAIN A VACUUM ON THE CONDENSER. ONLY 20\% OF TOTAL PRODUCTION REMAINS TO BE REINJECTED.

FIGURE 4 


\section{Drilling Problems, Special 80P Stacks}

The significant difference between drilling and completing Geysers wells and typical oil and gas wells, or even geothermal wells in the Imperial Valley, is the fact that conventional mud systems cannot be used over the producing zone.

Conventional muds would easily penetrate the highly fractured formation because of the underpressured conditions. The result would be severe lost circulation and/or plugging of the necessary channels through which steam communicates to the wellbore from the surrounding rocks.

The object is to drill an $85 / 8$ inch open hole into the steam producing fracture system in an underbalanced condition so that the productivity is never impaired. Cuttings removal is not a problem as the high velocity steam efficiently cleans the hole. It is necessary to cool the bit and clean the teeth. This is commonly done with air supplied by surface compressors at rates of 3,000-4,000 cubic feet per minute.

Above the target steam producing zone, 26 inch, $171 / 2$ inch and 12 inch holes are drilled with conventional mud systems with predictable problems of lost circulation, high bit torque and shock associated with the fractured hard rock system. The casing program will be described later in this section.

Within the target zone, compressed air adds oxygen to the returning steam and creates the highly erosive annular jet that is so damaging to drill string components. On the surface, the returning stream is contained under a rotating head (that must be continuously oiled and cooled by a water stream to protect the rubber) and diverted $90^{\circ}$ into the blooie line leading to the muffler and sump system. Mud and air drilling stack configurations are shown in Figures 5 and 6. 


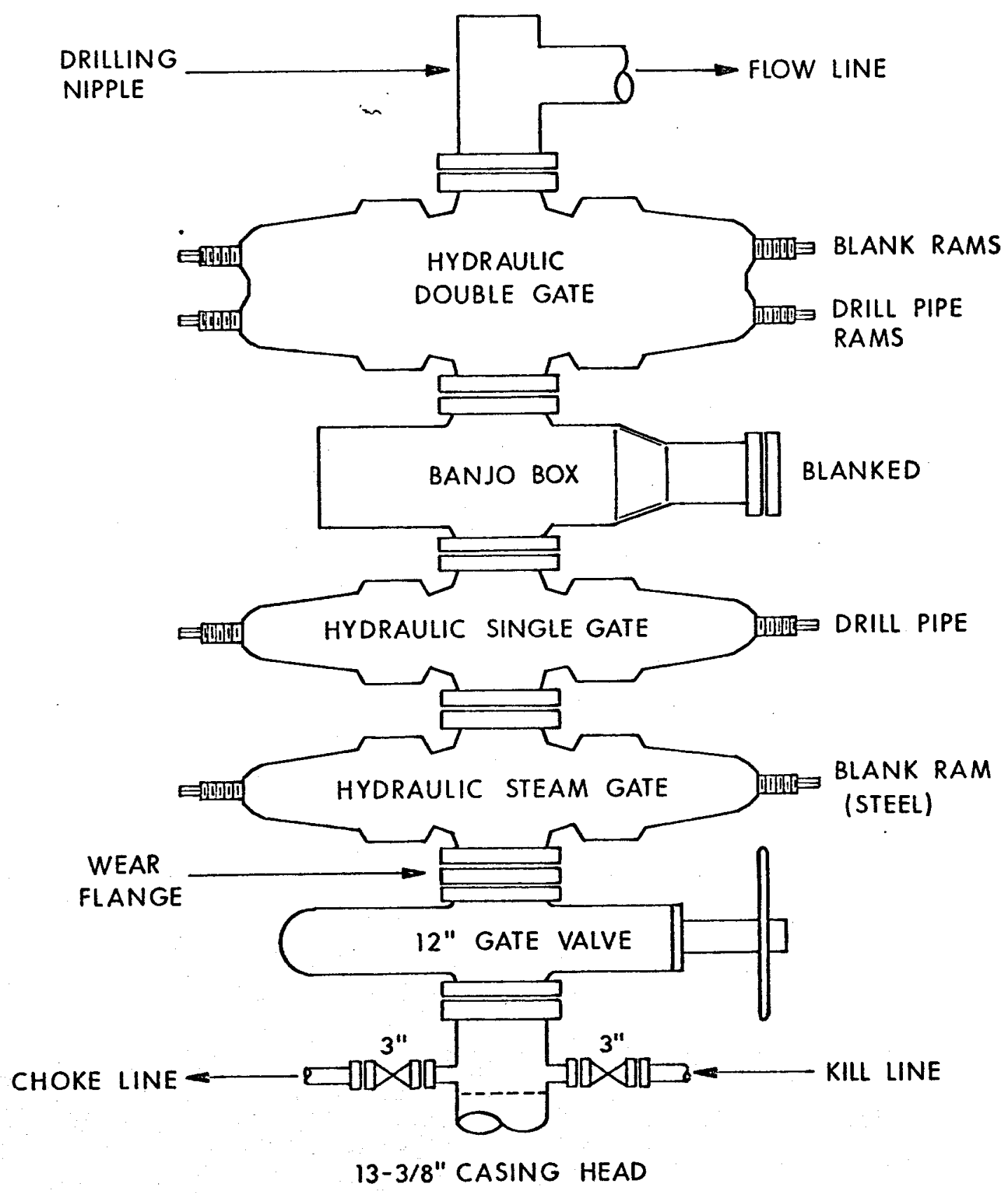

TYPICAL DRILLING WELL BOP STACK CONFIGURATION FOR DRILLING WITH MUD.

FIGURE 5 


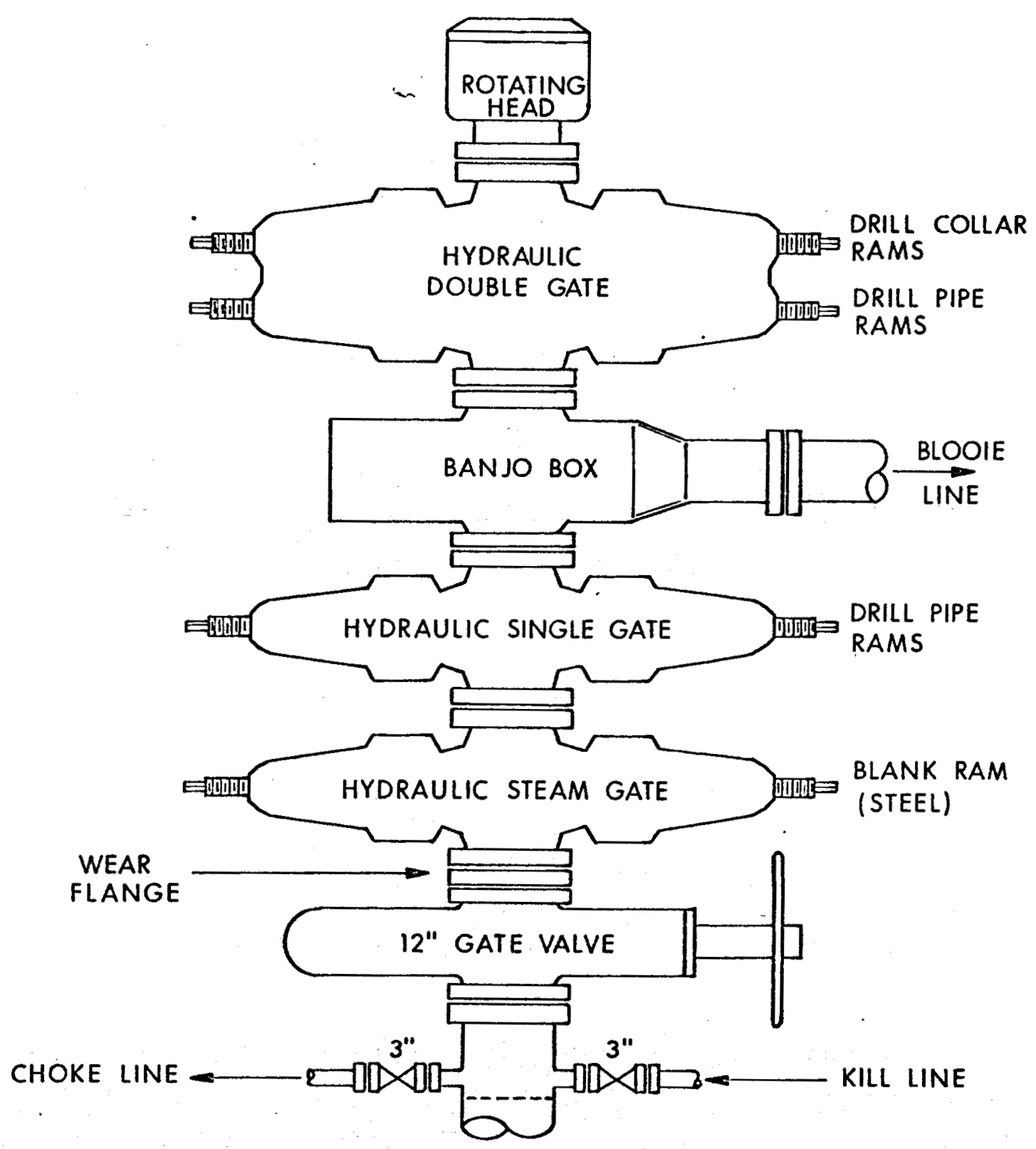

$13-3 / 8 "$ CASING HEAD

BOP STACK FOR AIR DRILLING. BANJO BOX DIVERTS AIR AND STEAM TO MUFFLER AND PIT.

FIGURE 6 
The steam diverter, locally called the "Banjo Box", is made from a heavy duty BOP body with 3/4-1 inch thick walls to contain the impact of high velocity particles. These units take severe wear and must be frequently repaired or replaced.

To minimize tool joint erosion, hard banding is placed on the bottom edge (see Figure 2) and the largest practical size drill pipe, perhaps 5 inch, $19 \mathrm{lb}$. , in preference to $41 / 2$ inch, $20 \mathrm{lb}$, is used to minimize shoulder width. The tool joint $O D$ is not hard surfaced to minimize intermediate casing string wear. Rubber drill collar protectors do not stand up long in the $400-500^{\circ}$ environment.

After dry steam has been contacted, the typical procedure is to continue drilling until enough fractures have been intersected to assure an adequate steam flow.

From this time, the completion process in The Geysers proceeds with very little formation evaluation. Because mud or water cannot be used across the dry steam zone, there is no way to cool the hole so that logging sondes with internal electronics can be reliably operated for extensive testing. The hot, dry and rough hole is not suitable for open hole logging or drill stem testing with devices using pads or rubber elements. And temperature and corrosion sensitive logging cables have been a weak link. Coring, DSTs and other work involving drill pipe tripping is rarely done due to downhole conditions and the difficulty of containing steam with stripper rubber.

Dresser Atlas recently announced successful high temperature logging in a $500^{\circ} \mathrm{F}$ open hole in Castle Rock Springs (The Geysers). Logs reportedly determined lithological characteristics and steam entry points using gamma ray neutron and compensated density surveys. A 5/16 inch Tefion insulated single conductor cable made by U.S. Steel Corp. was used (World 0il, Jan.1978, Page 15). 
Foam Drilling Systems

Other drilling fluids that have been tried include mist, a combination of air and water, and pre-formed stable foam. The advantages of foam, in principle, are that it offers a non-damaging method of holding backpressure on the fractures to control steam entry, and it can cushion the abrasive action in the annulus. Foam is also an excellent particle lifting material if it can be effectively jetted under material removed at the bit tooth contact point.

Some operators have found foam systems difficult to balance in the hole, and foam systems are somewhat sensitive to changing temperatures and pressure conditions. Application requires close coordination between drilling and engineering departments. Chevron U.S.A. has developed and licensed stable foam for a variety of $0 i 1$ field applications, and has experimented with foam in geothermal drilling.

\section{Difficult Locations, Directional Drilling}

Surface terrain at The Geysers consists of a series of very steep hillsides, ridges, and valleys with switchback access roads. Wells are grouped within 1/2-1 mile of the plant site and level locations must be prepared by expensive cut and fill work, Figure 7.

Such well groupings could be directionally drilled from control locations (pads). This would cut the cost of building multiple, individual well sites. However, directional drilling is also expensive, perhaps adding over $\$ 100,000$ to the cost of a Geysers well. The hot, fractured, abrasive rock is difficult enough to drill conventionally.

Deviation control with downhole mud motors is limited, of course, to that portion of the hole that is mud drilled. This is the major portion in most areas but some operators extend their air drilled sections as high 


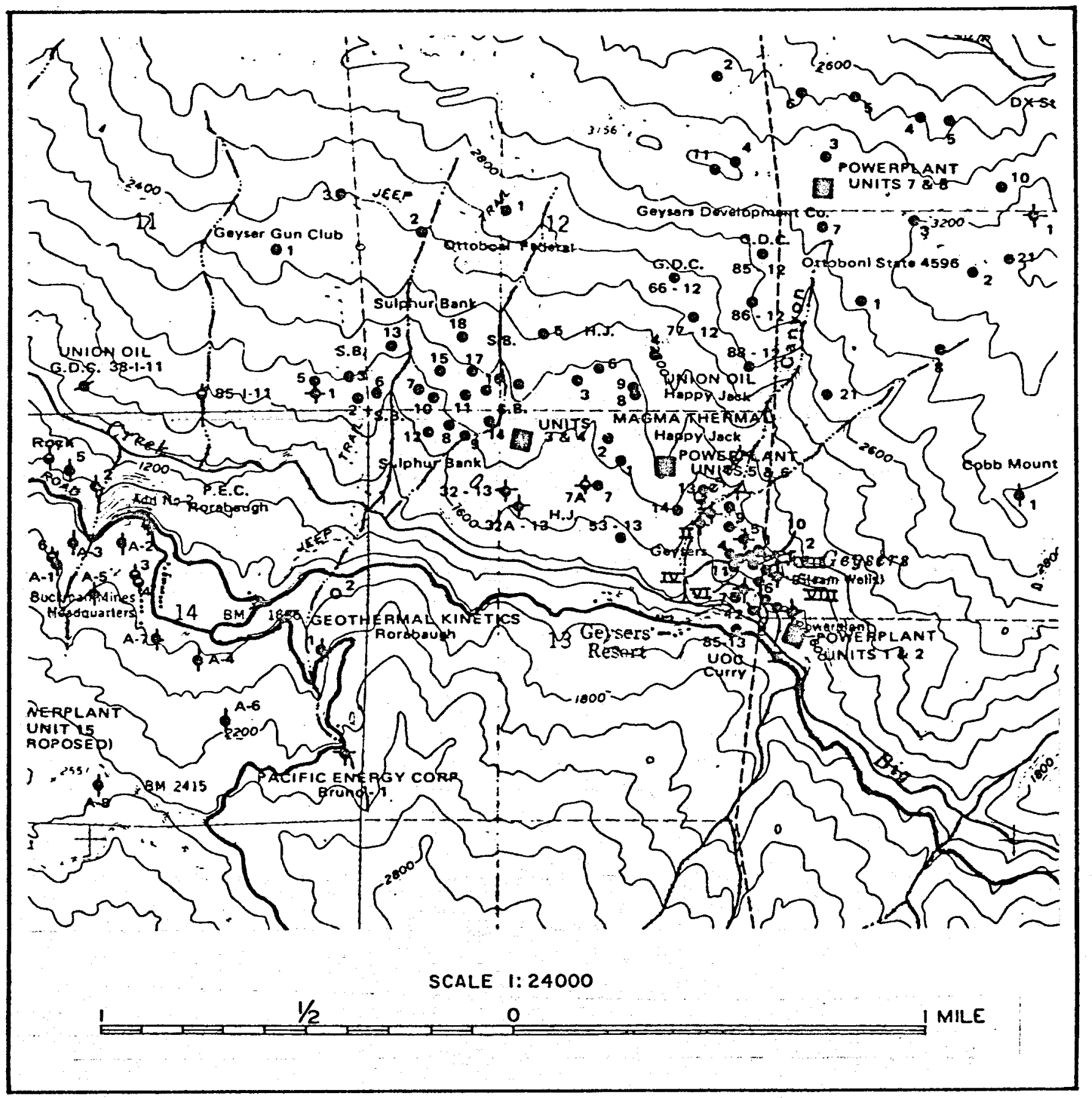

SURFACE ELEVATION CONTOURS AT THE GEYSERS. NOTE ELEVATION CHANGES OF $500 \mathrm{FT}$. PER QUARTER MILE IN PRODUCING AREAS. MAP DATE 1974. CONTOUR INTERVAL 200 FEET: 
as possible to increase penetration rates. The mud also cools the downhole environment to make gyroscopic surveying possible. The rubber stator in the Dyna Drill, a commonly used tool for deviating holes has a temperature limit of $350^{\circ} \mathrm{F}$.

Hole angle, and the manner in which it is created, greatly affects casing wear on intermediate strings, while drilling in open hole below. Rapid changes in angle (doglegs) in the upper part of the hole create greater lateral loads as drill string weight increases. Casing wear in the large diameter strings used could severely reduce already marginal collapse ratings, as will be illustrated later.

In shallower wells, slant hole rigs might be considered that higher deviations could be made from a pad, without a dogleg andition. This method is used on offshore platforms in certain types of shallow reservoirs.

A significant technology breakthrough in hot, fractured rock directional drilling capabilities would cut geothermal development costs in mountainous areas. The methods would be highly applicable to the "hot, dry rock" program, which will be described in a later section.

Normally, the procedure is to drill from single locations and utilize the natural borehole drift to cause the hole to intersect the maximum number of fractures, as there is a general trend to the fractures in the area-a phenomenon that is often associated with mountain forming diagenesis. This may not be true, however, in non-sedimentary, volcanic rocks in which the fractures may be radial, around intruding magna sills.

\section{Moving off the Rig}

The first steam test is made with an orifice plate in the blooie line. Later, more accurate isochronal back flow tests similar to those used on 
gas wells are completed.

To move off the rig, the drill string is pulled through the rotating head with the well blowing, and the master valve on the casing head is closed below the bit. When the BOP is removed, this valve then becomes the single shut-off device between the unconstrained $500 \mathrm{psi}, 500^{\circ} \mathrm{F}$ open hole steam source and the surface. To protect this valve during drilling, a wear ring is installed in the top flange, Figures 5 and 6 . Later, a second valve is installed so that the lower valve will never be operated against and be damaged by, differential pressure flow. Typical completed wells are shown in Figure 8. Wellhead features will be discussed in more detail later in this section.

It is generally conceded that completing Geysers wells under such "controlled blowout" conditions is a procedure that could be improved by innovative technology. Two Geysers producing wells have blown out; one in 1970 was controlled and abandoned within a few days; one in 1973 was not controlled until 1974 .

After the master valve is closed, and whenever the well is static, a small volume of steam may be vented from the casing head outlet to keep the downhole system hot and prevent condensation which could drain back down the hole and kill the well. This procedure has been modified in some later wells as will be discussed. When a well must be shut in, it is brought back on very carefully to prevent dislodging of sand and broken rocks from the fracture system. Once on stream, cyclonic dust trap along the line remove particles before they enter the turbine inlet, Figure 8 .

\section{We11 Control Considerations}

Workover procedures in The Geysers are complicated by the lack of well 

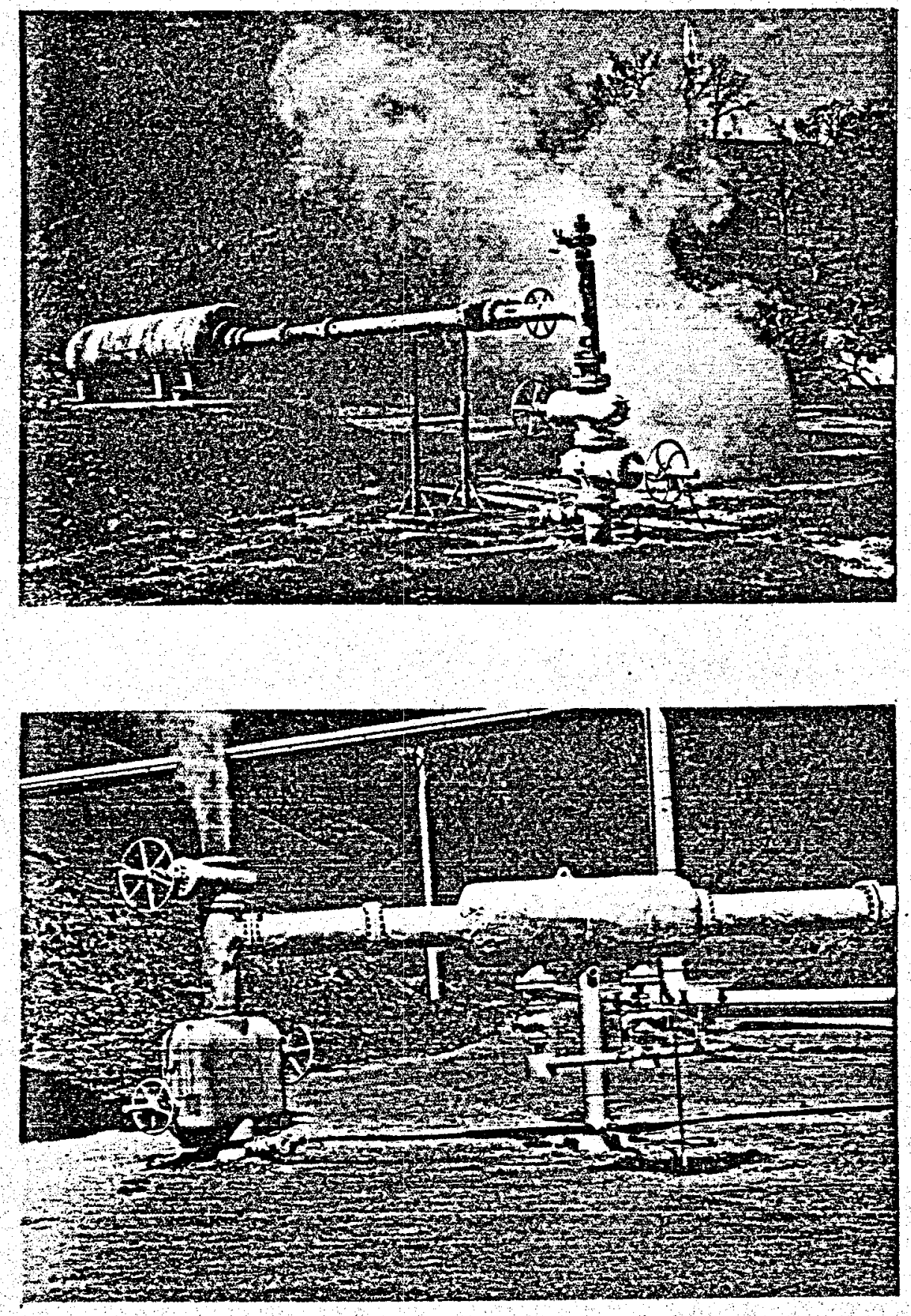

GEYSERS PRODUCING WELLS SHOWING DUAL MASTER VALVES, FLOW TEE AND CYCLONIC DUST TRAP ON FLOWLINE. Photographs Courtesy World 0il.

FIGURE 8 
control. Typically, industry relies on weighted mud to suppress formation pressure when mechanical shut off devices are removed from wells. At The Geysers, it is scalding, high energy heat that must be suppressed safely, and for long periods, if extensive well work is to be done. Industry at present has no elastomer material for BOP seals or for bridge plug or packer seals that can tolerate extended $500^{\circ} \mathrm{F}$ temperatures.

However, in recent completions in populated areas of The Geysers, steam venting of shut in wells thas, peen avoided. Some wells have been tested and temporarily plugged, while plant installations are being approved, by setting a bridge plug in the hole and capping it with cement. A7so, some wells have been killed for workovers with clean fluids and put back on stream by lightening the column with air or nitrogen. These have not been common practices.

Snubbing systems offer one possible method of working on live steam or hot water wells. New units presently active in the North Sea and Iran can handle very large strings such as $51 / 2$ inch or 7 inch. However, the major constraint again is the rubber sealing element, which on a snubbing unit is particularly critical.

The use of a stable, non-damaging foam in some combination with a reliable, temperature resistant snubber might be one approach to a geothermal well workover system.

Also in the area of well control, there presently is no method for automatically shutting in a steam producing well below the surface. Should the $133 / 8$ inch casing head, the master valve body, or the top of the surface casing itself split, crack or otherwise fail, steam would blow from the damaged equipment until the well was killed. 
Of course, the surface master valves could be equipped to operate as safety valves and close automatically when signalled. In the Geysers, such valves are utilized at plant inlets as a plant safety feature. Pressure relief valves in flowlines prevent gathering system pressure build up to 400-500 psi reservoir pressure levels.

Casing, Liner, Openhole Programs

Depending on hillside steepness, 150-200 feet of 20 inch conductor is cemented into a drilled 26-inch hole, Figure 9. Rocks are hard from the very start.

Surface pipe is typically API. $133 / 8$ inch, K-55, 61 pounds per foot (ppf), Buttress thread casing. High strength alloys are not required, but API round threads are not acceptable, as will be explained.

The $133 / 8$ inch casing is cemented - to surface with a slurry of Class G cement and Pozmix with $30-40 \%$ silica for strength at high temperature, and retarder. Stab-in techniques are frequently used in large casing (slurry pumped down drill pipe through a bottom stab-in connection) to reduce pumping time and water storage requirements. The pipe-formation bond restrains the pipe against thermal expansion and contraction. The string can also be pre-tensioned during cementing to compensate for future expansion. Special attention to collapse is important in large diameter pipe. This will be discussed later in this section

The $133 / 8$ inch is normally set below any surface water flow and/or through unstable serpentine stringers. In some locations it may be possible to air drill below the surface pipe to increase penetration rate and avoid lost circulation. In other areas, mud drilling must be continued, due to deep water flow. 


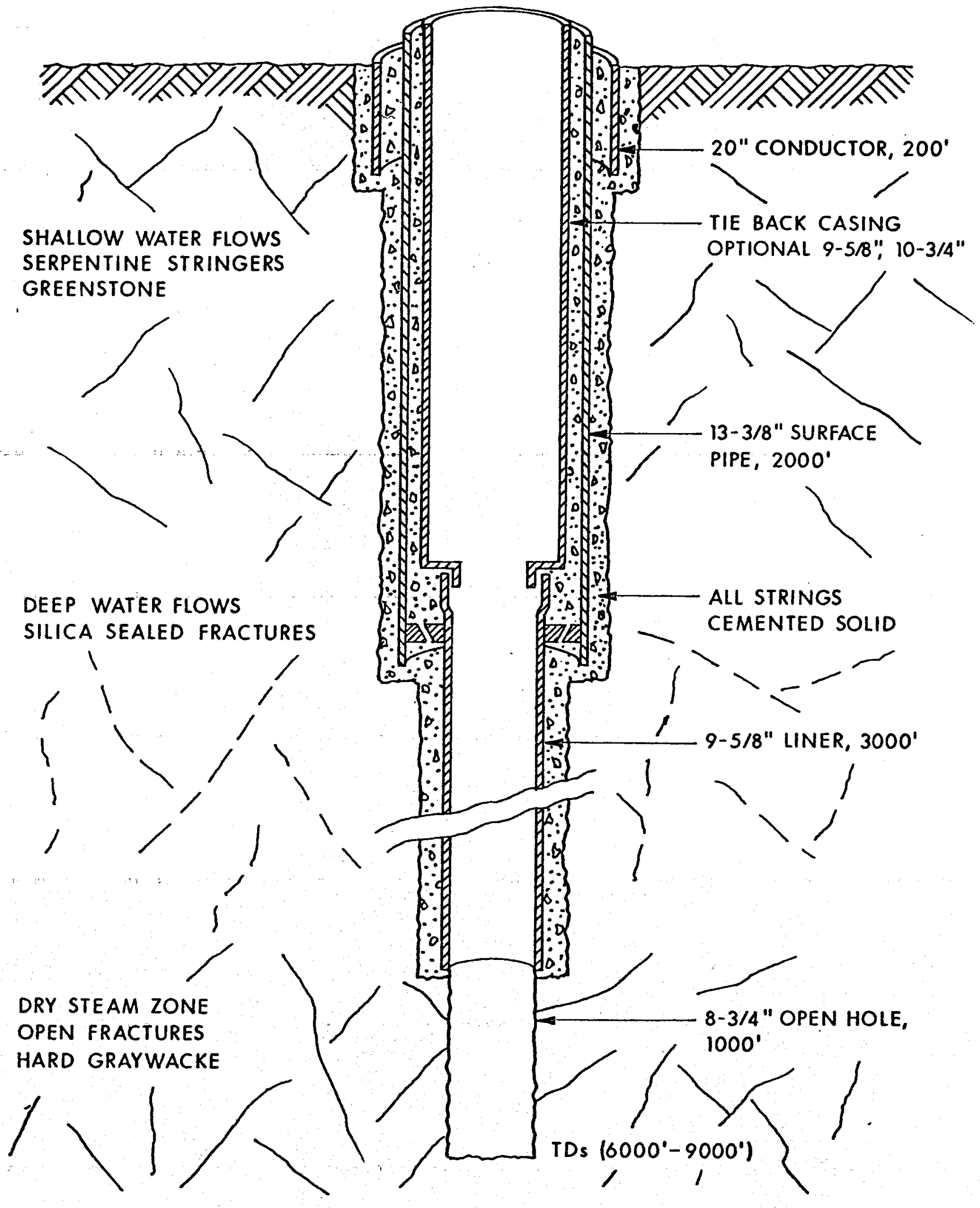

MODERN GEYSERS CASING PROGRAM. TIE BACK CASING IS NOT USED IN ALL PRODUCING WELLS. 
A $121 / 4$ inch hole is drilled from below surface pipe to the top of the expected steam zone. In this hole, high mud temperatures are a problem and chemical thinning and cooling with large fans blowing across the shale shaker can usually control thickening. Mud temperatures run about $180^{\circ} \mathrm{F}$ but have been considerably higher at times.

A typical depths of 5,000-6,000 feet, a drilling liner of $95 / 8$ inch, 36 ppf, N-80, Buttress thread casing (with heavier 40 ppf joints on bottom for greater collapse resistance) is landed and hung on a liner hanger, 200-250 feet up from the $133 / 8$ inch shoe. The liner is cemented solid with retarded Class $G$ and Pozmix cement with $30-40 \%$ silica, and friction reducer.

When liner cement has set, the drilling system is converted to air by removing the mud flowline and installing the Banjo Box and rotating head.

Typically, an $83 / 4$ inch bit is run and about 1,000 feet of hole is drilled into the fractured zone containing dry steam. Drilling is stopped when sufficient steam flow is judged to have been opened. Preliminary tests are made while the wellbore is cleaning itself through the diverter, rock trap and muffler.

\section{Casing Design, Installation Factors}

It has been common practice to complete the well as a "barefoot" open hole completion, with drilling liner and surface pipe serving as tubing. This configuration gives minimum restriction to flow. Disadvantages are that the well is left with drilling damaged liner and large diameter casing as the only wellbore protective strings.

Some operators install a tie back production casing string from liner hanger to surface, and cement this string to surface, Figure 9. The cement 
presumably bonds the production string to the surface casing and adds strength and collapse resistance to the downhole system. In an oil or gas well, the tie back string could be run after the lower hole was drilled to prevent drill string damage. This is not practical to do in The Geysers without killing the well.

Casing size can be a big completion cost factor and the entire tubular program would, of course, be a function of depth and maximum friction loss allowable. The $95 / 8$ inch drilling liner can be extended to surface which would cut steam flow but give added annular space for proper cementing, i.e. a difference in liner OD to surface pipe ID of 2.89 inches or a sheath thickness of 1.445 inches. Or a $103 / 4$ inch string could be used to improve flow rates in which case the annular area would be reduced to a cement sheath thickness of 0.88 inches, for perfectly centered pipe.

Too small a cement sheath would reduce cement strength and bonding ability to contain thermal expansion of the inner string, although even low strength cement can support high axial loads. And a weakened cement sheath would continue to act as an insulator and provide some string support because it cannot escape, and bonding as a fluid seal is not required in this application.

The tie back string normally is stabbed into the liner hanger using a nipple with chevron seals that engage a polished bore receptacle. The string can be cemented by circulating slurry before completing the seal; or port collars may be used to circulate: Temperature sensitive seals in these applications would be "backed up" with cement. Higher strength cement may be used by reducing the pozzolan type lightener. Silica is still added for temperature resistance. 
Thermal Stress on Casing, Thread Selection

High strength steel alloys are not required downhole for the minimal pressures encountered, and the carbon steel metallurgy is adequate in the dry, non-corrosive producing environment.

API Buttress threads are commonly used on casing strings in most geothermal applications to handle additional stresses imposed by thermal elongation and contraction, Figure 10.

This problem was highlighed in California steam injection wells several years ago when numerous casing failures were observed in cyclic steam wells. During the steaming cycle, the casing would elongate, subjecting the string to compression loads that plastically yielded the pipe, actually shortening the string. When the string cooled, during the production phase, the shortened string caused severe tension loading. Usually API round thread pins pulled out of the boxes; the pipe body parted in some cases.

Examination of the Buttress thread form shows that, in tension, pin threads oppose coupling threads with a nearly flat shoulder, reducing the inclined plane lifting effect that mating API round $V$ threads have.

Industry suppliers also offer premium, non-API casing connections with proprietary thread forms that offer greater strength than API Buttress threads, and additional features such as multiple seals and postive shouldering, similar to a tool joint, figure 10. API tapered threads rely heavily on the pressure of thread dope between the roots and crests of mating threads to complete a fluid seal. All premium joints have metal to metal sealing features; some have threads that also seal against each other. 


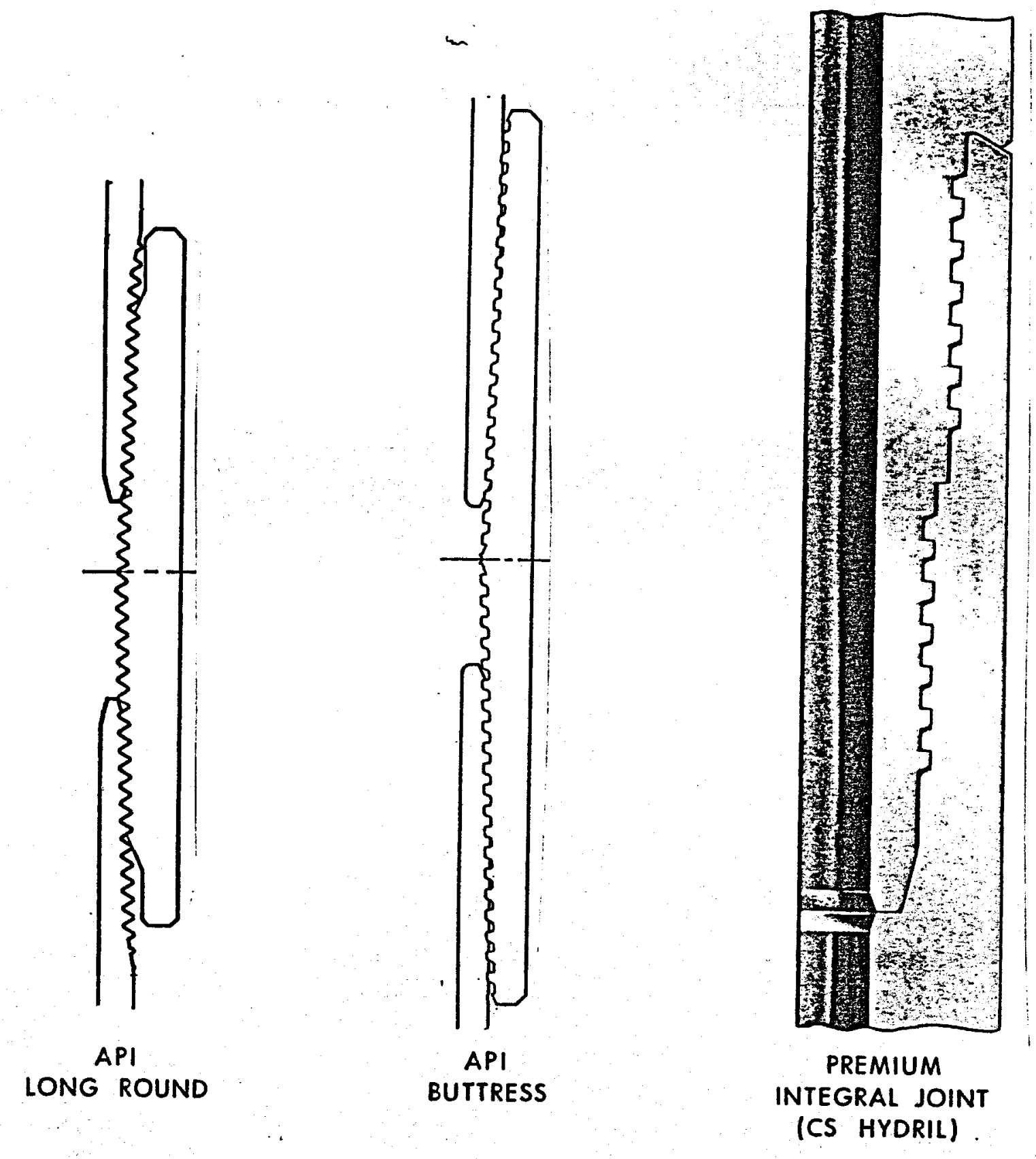

COMPARISON OF TAPERED API CASING THREAD FORMS ILLUSTRATES INCREASED TENSION LOADING CAPABILITY OF BUTTRESS THREAD. PREMIUM NON-API THREADS OFFERED BY SEVERAL FIRMS ALSO HAVE SHOULDERING FEATURES FOR HIGH COMPRESSION LOADING, AND METAL TO METAL FLUID SEALS. 
A quick reference to various thread forms is available in the World 0il Tubing Tables, World 0il, January 1977. Suppliers of premium connections also advertise in Composite Catalog, Gulf Publishing Co., Houston.

In any case, it is necessary to have couplings as strong as the pipe body. And the pipe body must be designed to handle thermal load changes. Fortunately, most geothermal applications will not subject casing strings to cyclic thermal loadings once production commences.

Conversely, movement in unrestrained tubing strings can be great. We11heads designed to accomodate this movement to prevent buckling are illustrated later in this section.

Collapse resistance is a critical consideration in large diameter casing such as the $133 / 8$ inch string. This pipe has an API collapse resistance of only 1,130 psi compared to an internal yield pressure of 3,090 psi. And the weakening effects of casing wear and $500^{\circ} \mathrm{F}$ temperatures should be considered. -

Several operators have collapsed casing in geothermal operations by trapping water behind the pipe during cementing operations. It should be remembered that any water or mud filled voids in the cement column opposite non permeable formations--and particularly in the annulus between surface pipe and conductor--will be heated to $400-500^{\circ} \mathrm{F}$ temperatures during production. And the entrapped fluid must expand and in so doing, it exerts pressure on the casing that can easily exceed collapse ratings. To avoid this, small diameter pipe is often run into the $20 \times 133 / 8$ inch annulus to fill the space with cement.

The same problem also exists between $133 / 8$ inch surface casing and $95 / 8$ inch tie-back liners that are sealed into expanding type geothermal wellheads. In this case, the casing head outlets must be left open to prevent water or condensate entrapment in the annulur space where it could be heated 
by steam flowing inside the liner. These problems have actually occurred and the expense of repairing collapsed casing is great.

A poor cement job on surface pipe can also lead to external casing problems. Channels and voids that contact permeability to surface water can expose the casing surface to water that contains oxygen and is thus potentially corrosive. Extensive contact with colder surface water can also cool the pipe and promote thermal stresses or lessen the insulating properties of the cement sheath.

The special problems with geothermal casing strings that have been discussed above (thermal movement, collapse, external corrosion and drill pipe wear) are illustrated in Figure 11.

Casing Heads, Valves

Geysers surface systems handling dry steam can be simple because of the moderate pressures and non-corrosive fluid being handled. In non-populated areas where continual venting is permitted, and tie back casing is not used, a $133 / 8$ inch, 2,000 or 3,000 psi W.P. casing head is slipped on the $133 / 8$ inch surface pipe and welded, Figure 12. This head, also known as a Mud Cross, has a 12 inch flange on top, two flanged outlet ports, and an internal diameter of about 12 1/2 inches. This head is not threaded onto the surface pipe although both threaded and weld types are available.

In the simple completion illustrated in Figure 12 , where the casing head is welded onto the surface pipe and there is no tubing or tie back casing inside the surface string, the master valve is flanged directly to the casing head. For a positive seal, metal to metal seal rings fit into circular grooves in the mating flanges. 


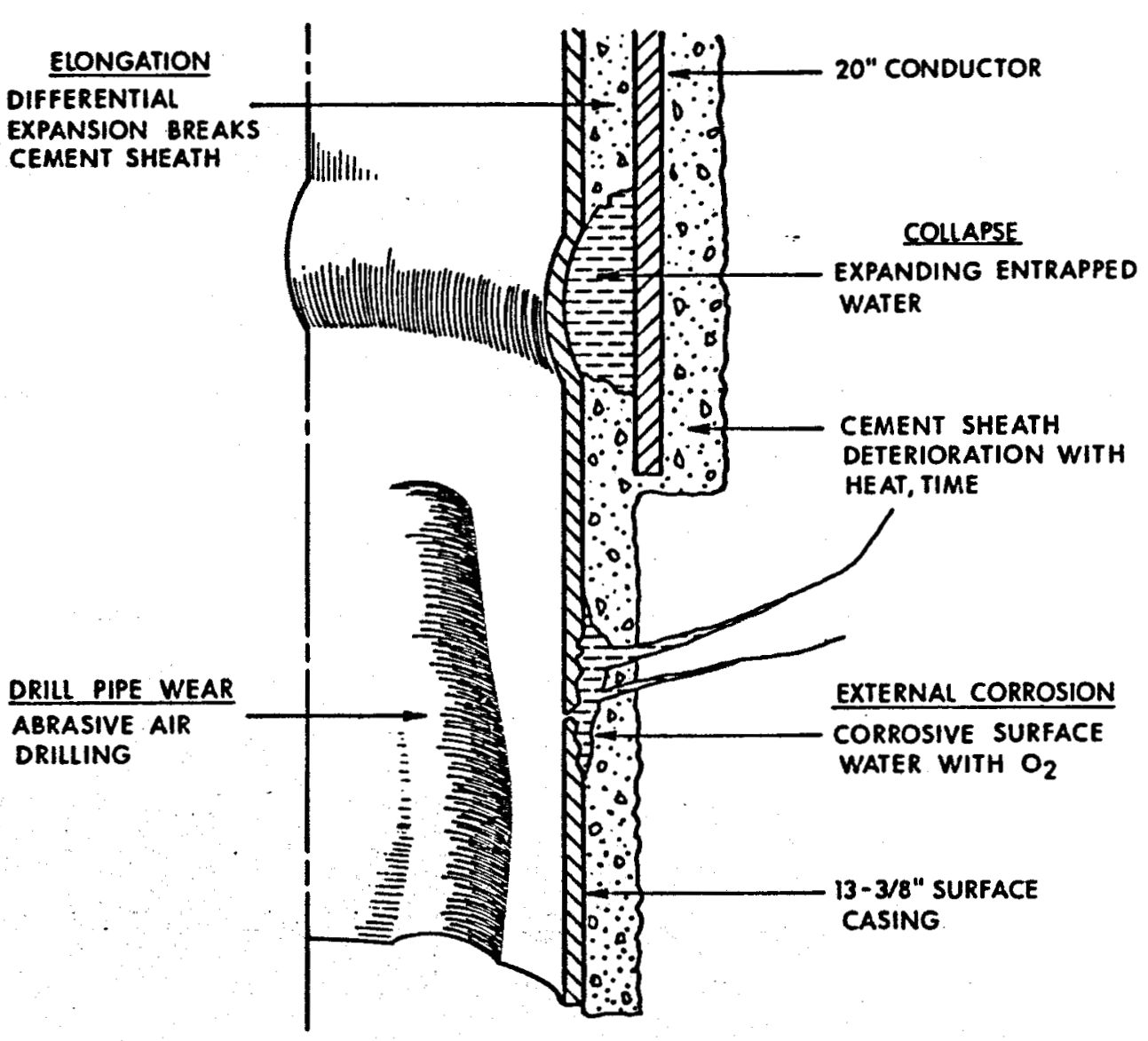

CASING PROBLEMS THAT CAN BE MORE SEVERE IN GEOTHERMAL WELLS DUE TO HIGH TEMPERATURES AND LARGE DIAMETER STRINGS COMMONLY USED. 


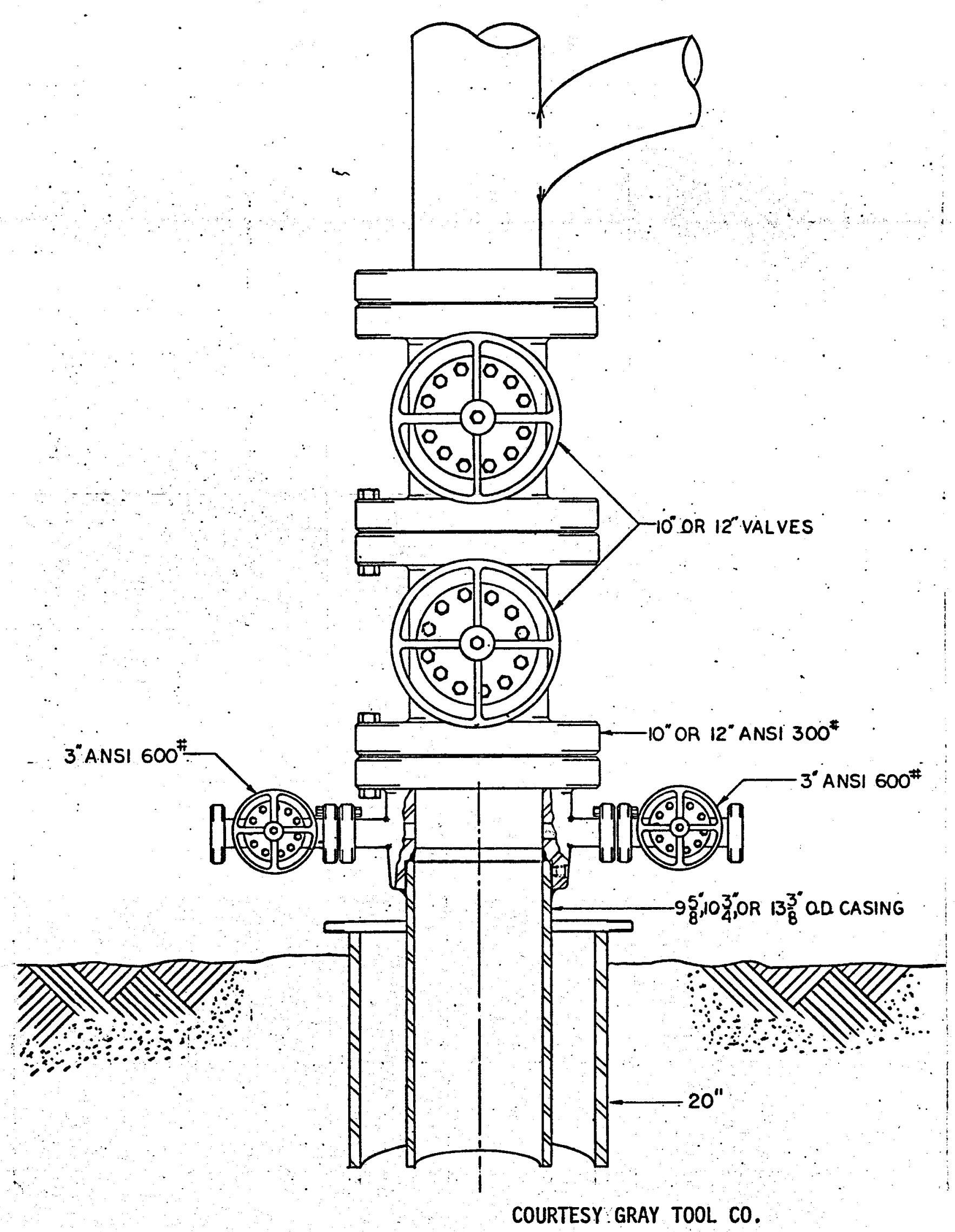

WELD TYPE CASING HEAD WITH TOP FLANGE AND SIDE PORTS AND DUAL MASTER VALVES. NOTE: ALL ANNULAR SPACES BETWEEN CASINGS AND OUTSIDE CONDUCTOR SHOULD BE CEMENT FILLED.

FIGURE 12 
Master valve design is very important. It must be extremely rugged to withstand the high compressional and shock loadings imposed by 40-50 tons of BOPs, Banjo Box, mud flowline and/or rotary head equipment attached to it during the drilling phase. Geothermal-service valves must also be designed to present a full opening to steam or water flow without recesses that can fill with scale material that plugs flow or prevents valve operation. And they must operate under extreme temperature conditons without galling or seizing. Valves are available with special geothermal trim that offers corrosion and/or erosion-corrosion resistance. For corrosive fluid production, equipment can be made from 316 stainless steel. Supplier recommendations should be followed in metallurgy selection.

Geothermal valves should be designed so that the gate contact points are forced outward by internal wedges, forming tight metal-metal seals so that steam or water cannot enter the valve body and foul internal components or contact the stem packing, Figure 13. One such valve offers these features on both open and closed positions and the operator must be aware of this feature, and open the valve completely to actuate the seal.

\section{Expanding Wellheads}

Where an inner string extends through the casing head, it may not be desirable to hang or positively secure that string to the casing head, as would be done in an oil or gas well. In the latter case, seals between casing strings are critical, to prevent dangerous escape of high pressure gas or oil into lower pressure rated casing strings. Also in such cases, where inner string expansion is expected in high temperature hydrocarbon producers, movement usually occurs in a downhole sliding sleeve in a liner hanger. 


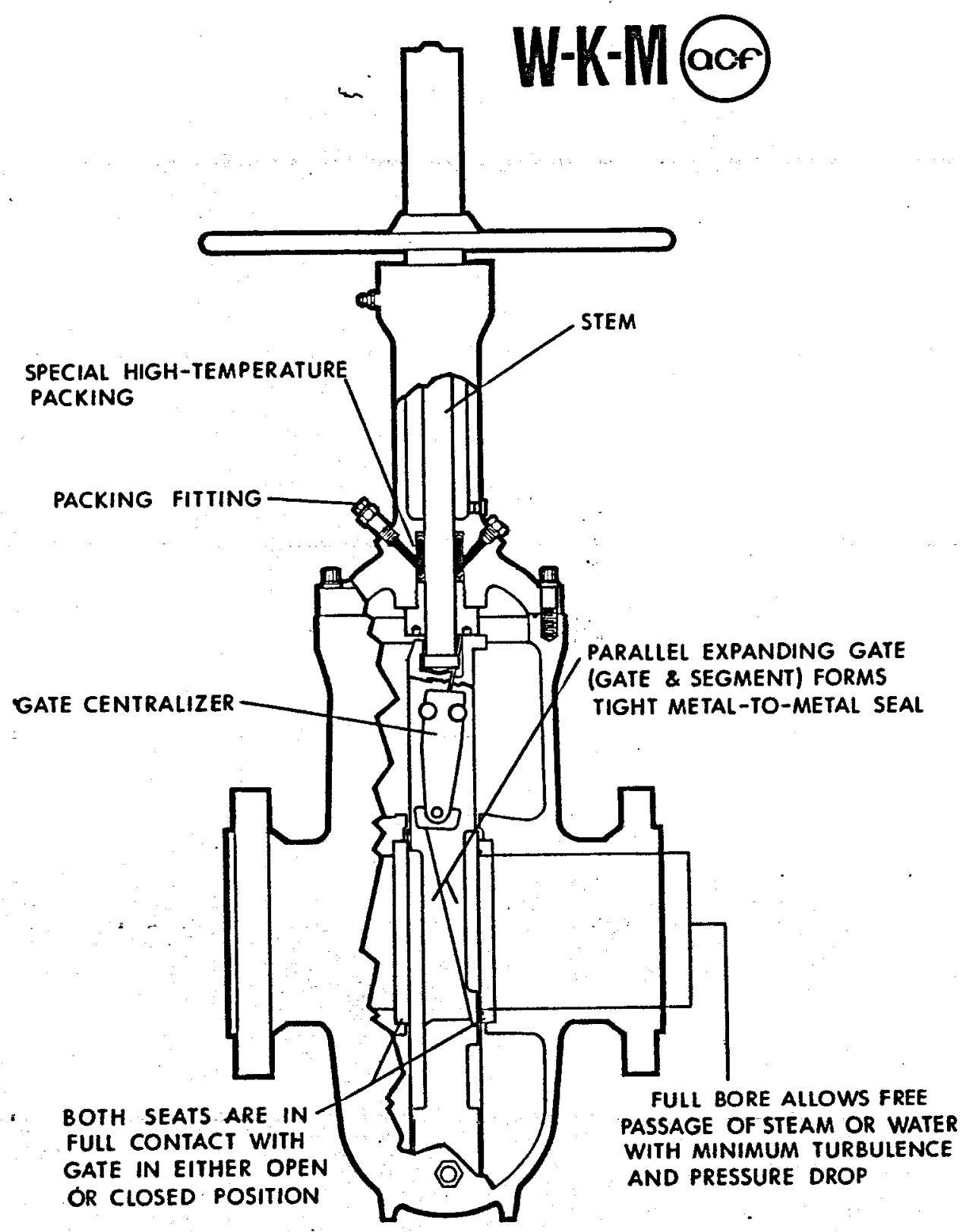

GEOTHERMAL VALVE WITH EXPANDING GATE PROTECTS INSIDE HOUSING AND STEM PACKING FROM HOT, SCALE BUILDING FLUIDS. POW-R-SEAL MODEL SHOWN IS RATED TO $550^{\circ} \mathrm{F}$. OTHER COMMERCIAL VALVES ARE AVAILABLE,

FIGURE 13 
However, reliable downhole sliding seals have not been perfected, for geothermal wells, and it may be undesirable to solidly connect concentric casing strings at the surface, because differential expansion may buckle or permanently damage the pipe.

The solution is to allow the inner string, commonly $95 / 8$ inch or $103 / 4$ inch tie back casing, to move vertically within the wellhead. This is accomplished by installing an expansion spool between the casing head and the master valve, Figures 14, 15.

Several companies offer expansion spools. All models have a seal between the casing and the expansion spool bore composed of high temperature, asbestos based packing, backed by addition of plastic temperature resistant packing applied through injection ports. Spool length can vary as needed, common string movement is $8-14$ inches.

One proprietary design has the seal attached to the casing so that it operates against a polished spool bore. Other models have stationary seals in the spool through which the casing stub moves. Installation of an expanding wel thead should not be attempted by inexperienced field personnel. It is critical to seal life and reliable operation that the casing be centralized accurately within the expansion spool.

And, as mentioned earlier, it is extremely important that no water filled spaces be entrapped during wellhead installation, as expanding fluids heated to $500^{\circ} \mathrm{F}$ temperatures by steam production can easily collapse casing. Outlets on the $133 / 8$ inch casing head must be left open or adequately vented to prevent formation of entrapped condensate between $95 / 8$ and $133 / 8$ inch strings. Pressure relief features in other locations on the wellhead should be utilized. It is also possible to collapse inner strings by improperly injecting plastic sealant from high pressure hand guns. 


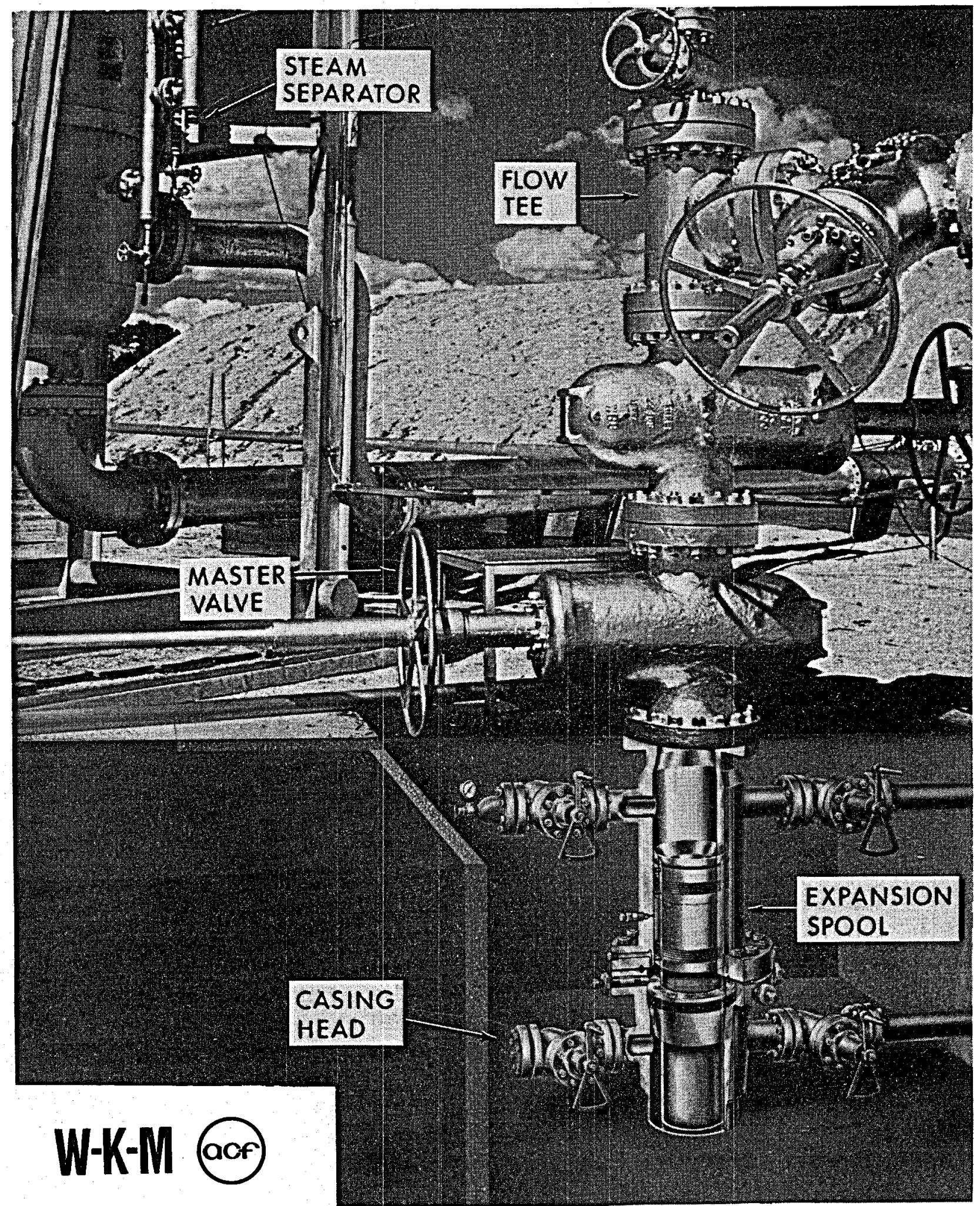

EXPANSION SPOOL WITH SEAL AFFIXED TO CASING. SURFACE EQUIPMENT IS AN ACTUAL INSTALLATION ON A WET STEAM TEST WELL.

FIGURE 14 
Additional technical information on geothermal wellheads should be obtained from manufacturers. Products of two major suppliers of geothermal surface equipment are illustrated in this report. Other manufacturers which offer geothermal wellheads and relevant equipment are listed in Composite Catalog, Gulf Publishing Co., Houston. The American Petroleum Institute (API) has no standards for geothermal wellhead equipment, so API Spec 6A on wellheads is little help in selecting such equipment. Suppliers should be contacted to clarify actual pressure ratings of components listed in ANSI ratings. These ratings are old nomenclature that does not indicate pressure. A 600 ANSI flange, for example, has an ANSI pressure rating of 1,440 psi-at $100^{\circ} \mathrm{F}$. An API 2000 flange has a 2,000 psi rating at $100^{\circ} \mathrm{F}$.

Industry has the capability to produce as reliable a wellhead as needed if cost requirements can be met, and if accurate specifications can be given ahead of time. For example, wellheads have been supplied for corrosive natural gas wells in a high temperature field in Indonesia for locations that have 7 inch tubing, $4000 \mathrm{~F}$ temperatures, very high surface pressures, and flow rates of over 250 million cubic feet of gas per day. The cost of this wellhead for a geothermal application may be prohibitive, but it illustrates what can be made available on demand. 


\section{IMPERIAL VALLEY}

Development Status

Imperial Valley development by private enterprise is still in the competitive stages as evidenced by considerable exploration, resource evaluation and leasing activity. Thus, many details of reservoir properties, actual temperatures and potential flow rates are not available.

A federal test site was established at East Mesa, near Holtville, and five wells were drilled by the Bureau of Reclamation between August 1972, and June 1974 (see map Figure 16). The site now consists of one active water source well, a water handling and transfer system, and one injection well, which are made available to bona fide organizations desiring to evaluate geothermal processes. Status reports from East Mesa are one public source of data on early Imperial Valley drilling and completion operation.

It is important to understand that in early federal test projects, and in certain other privately sponsored operations in the Imperial Valley, water has been handled in a manner that creates problems that can likely be avoided in actual commercial enterprises. At East Mesa, for example, production is flashed into an open holding pond and subsequently pumped into an injection well. Such conditions have produced horror stories of scaling problems that have negatively influenced many people's concepts of the Imperial Valley's geothermal potential. Basic technology which is outlined by R. M. Jorda in earlier and accompanying reports and verified by operators' experience and plans for development, indicate ways must be found to recover heat from the water without flashing, to minimize scale buildup. 


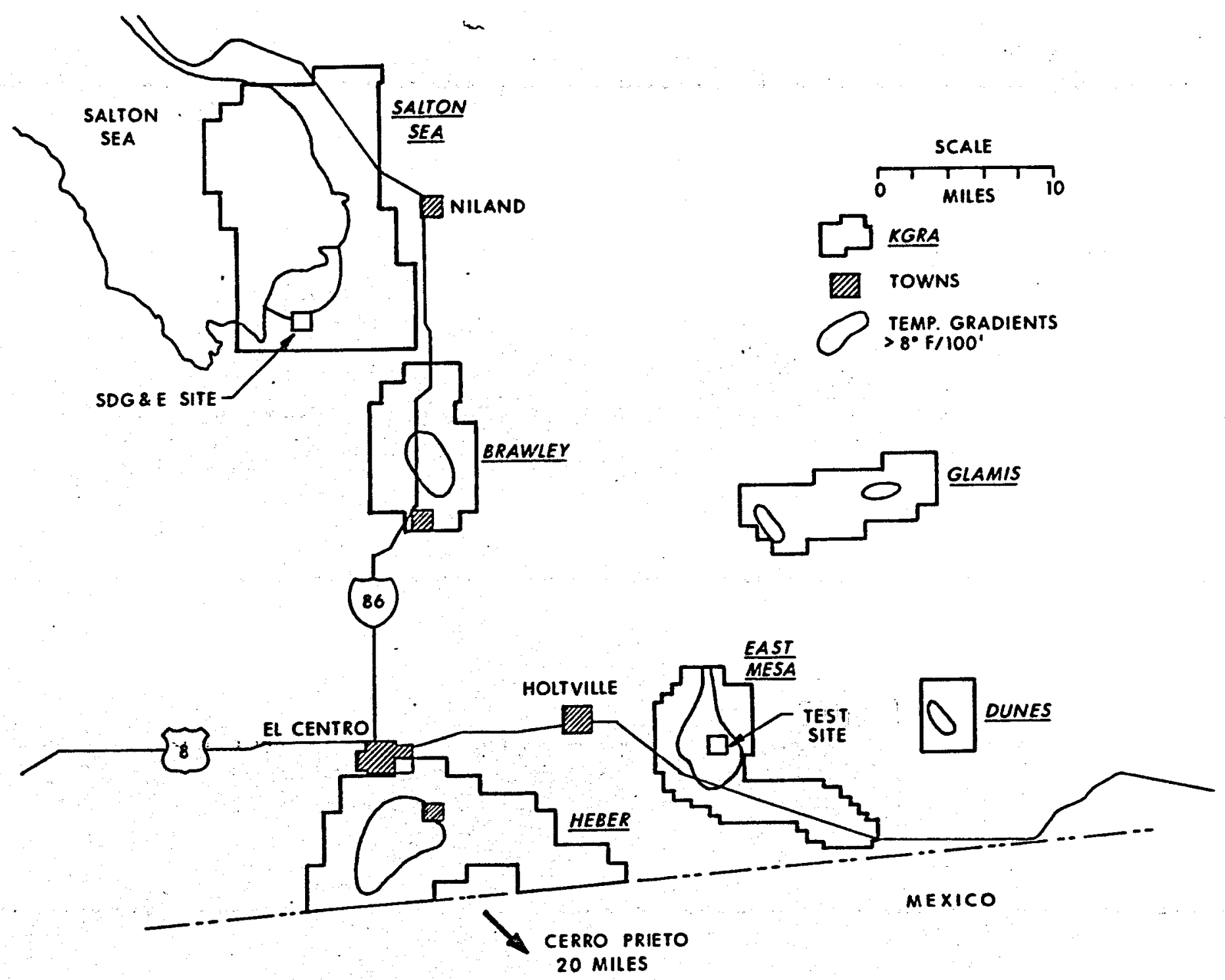

IMPERIAL VALLEY OF CALIFORNIA, 100 MILES EAST OF SAN DIEGO. KGRAS ARE FEDERALLY DESIGNATED KNOWN GEOTHERMAL RESOURCE AREAS.

FIGURE 16 
Several operators are optimistic about rapid development al though no commercial plants are in operation. Near Niland, San Diego Gas and Electric Company is evaluating resource-potential and will likely be the first buyer of geothermal energy in the area. In the Heber area, a major oil company has development plans laid for a project that could eventually include a 500 megawatt plant utilizing 6 million barrels of water per day. Magma Power is installing a $10 \mathrm{MW}$ pilot plant near East Mesa to evaluate its Magma Max Binary System.

In October, 1977, San Diego Gas and Electric testified before a California legislative subcommittee that it did not yet have sufficient data to support commercial development. Again, testing that led to this comment is primarily a result of continuing study of hot water in flashing conditions, in this case in the Niland area... Scaling in pipes and pressure vessels was mentioned as a major deterrent to development.

Perhaps commercial development plans may be fairly well defined within two years and by the mid 1980s a substantial new source of electricity for the San Diego-Imperial Valley area could be a reality. At least one operator has said it is ready to develop now if the utility would install a plant.

\section{Comparison with The Geysers}

Several basic differences cause Imperial Valley completions to vary greatly from those in The Geysers:

- Target production is very high volume hot water $(40,000-100,000 \mathrm{bpd} /$ well) with high mineral content.

- Temperatures can be higher or lower depending on location within the 2,000-3,000 square mile Valley area, varying from $350^{\circ} \mathrm{F}$ to nearly $700^{\circ} \mathrm{F}$, in the more attractive producing areas. These higher temperatures approach the heat treating levels of some steels. 
The geothermal water source bed is a major sedimentary basin and the producing section includes shales and thick, loosely consolidated sands with widely varying. permeabilities.

Downhole and surface systems are wetted by hot water and are subject to corrosion and scaling.

- Surface terrain is nearly flat and wells are in or near irrigated and cultivated land with major canal systems that are sensitive to subsidence.

- Reservoir pressures are higher than in The Geysers, but are still underpressure compared to hydrostatic levels. Mud systems can be used for drilling and control, but formation breakdown pressures are sensitive to mud weight.

Dritling is neither difficult nor expensive and directional wells can be utilized for more efficient pad type development.

- Surface systems are similar to those used in The Geysers, i. e. large diameter valves and flowlines, and thermal expansion equipment is required. Natural flowing surface pressures are relatively low, being a function of density changes in the flowing water column with temperature rise.

- Disposal of cooled water is a major consideration as all effluent must be reinjected. However, injection pressures are not high, in the absence of formation plugging, as pressure of the "cold" water column exceeds that of the reservoir.

\section{Reservoir, Fluid Properties}

The Imperial Valley geothermal reservoirs are porous sand bodies deposited in the Salton Trough, a complex rift valley which is the northerly 
extension of the Gulf of California. The heat source is a buried magma body. Underground water is supplied from the Colorado River to the East and it essentially moves horizontally into the permeable sands, collecting high concentrations of minerals in the process. Above the heat source, the water temperature is increased and the less dense liquid moves vertically toward the surface where it is subsequently cooled. In the cooling process, minerals are deposited in the rock pore spaces and fractures.

Over geologic time, this mineral deposition has formed a cap rock of silica-filled sedimentary rock that prevents further natural water loss. The system is complicated by deep fracturing associated with the same plate tectonics that have created California's well known San Andreas fault. Major geothermal fields are located by increased temperature gradients, which can be ten times normal, $i$. e. up to $10^{\circ} \mathrm{F} / 100$ feet.

Late Tertiary sediments filling the Salton Trough consist primarily of poorly cemented sand, silt and shale. There is clay present which will likely swell on contact with fresh water and cause productivity impairment. Many wells have been logged with Schlumberger's Coriband or Saraband log suites, using best available temperature resistant tools and lines, to identify porosity and sand-shale sequences. One operator has a project underway to correlate $\log$ and core data for more accurate application of logs. Porosity and permeability can vary greatly from zone to zone and one major completion consideration is the fact that most operators open the gross interval to production by running long, uncemented slotted liners. Such systems do not permit evaluation and treating of separate zones with individual producing characteristics, i. e. a few very high permeability streaks may be contributing a high percentage of total flow. Excessive flow velocities 
from thin zones could lead to long range problems such as wellbore instability, sand flow, in situ scaling (from pressure drop) and liner slot erosion.

Both porosity and permeability decrease with depth and there is a reasonable correlation of porosity to permeability. East Mesa wells in the 5,000-8,000 foot depth range have average porosities over short intervals of $30 \%+$ at 2,000 feet, grading to $20-25 \%$ at 6,000 feet. Corresponding permeabilities were in the order of $100 \mathrm{md}+$ at $28 \%$, decreasing to $10 \mathrm{md}$ at 20\%. Permeabilities of over one Darcy are not uncommon in Imperial Valley wells in shallower zones. In East Mesa wells, there is nearly a 1:1 relation between horizontal and vertical permeability.

Reservoir temperatures vary greatly and this variation makes or breaks the economics of commercial applications, as heat is the product being sold. East Mesa wells had shut in bottom hole temperatures of $399,380,315,354$ and $309^{\circ} \mathrm{F}$ at depths of $8,030,6,005,6,016,6,205$ and 6,231 feet, respectively. In the Niland area, closer to the Salton sea, one operator has a 3,000 foot well with $500^{\circ} \mathrm{F}$ temperatures, and a 4,600 foot well with $618^{\circ} \mathrm{F}$.

Concentrations of total dissolved solids (TDS) are highest around the Niland area where the brines average 200,000-300,000 ppm TDS. In Heber, TDS levels are about 14,000 ppm; around Brawley, 80,000 ppm; in East Mesa, 2,000 ppm; and in Mexico's Cerro Prieto development, south of Heber, $20,000 \mathrm{ppm}$.

The waters contain a large number of minerals besides the predominate sodium chloride. The chemical analysis of unflashed East Mesa Brines reveals over 20 elements, see Table 1. In Cerro Prieto, silver is reportediy recovered from scale as a commercial by-product. Produced brines have $\mathrm{pH}$ values of about 6.0 , or higher. 
TABLE 1 -ANALYSIS OF UNFLASHED EAST. MESA GEOTHERMAL BRINES, JUNE, 1976

\begin{tabular}{|c|c|c|c|c|c|}
\hline \multirow[b]{2}{*}{$\begin{array}{l}\text { Conductivity }\left(25^{\circ} \mathrm{C}\right) \\
\text { Chloride (Cl) } \\
\text { Sulfide (S) } \\
\text { Silica (SiO } \\
\text { pH } \\
\text { Total Dissoived Soli } \\
\text { Iron (Fe) } \\
\text { Lithium (Li) } \\
\text { Potassium (K) } \\
\text { Magnesium (Mg) } \\
\text { Manganese (Mn) } \\
\text { Barium (Ba) } \\
\text { Bicarbonate ( } \mathrm{HCO}_{3} \text { ) } \\
\text { Sulfate (SO } \\
\text { Fluoride (F) } \\
\text { Ammonia (NH4) } \\
\text { Cesium (Ce) } \\
\text { Bismuth (Bi) } \\
\text { Arsenic (As) } \\
\text { Antimony (Sb) } \\
\text { Sodium (Na) } \\
\text { Calcium (Ca) } \\
\text { Strontium (Sr) } \\
\text { Boron (B) ( } \mathrm{Br} \text { ) } \\
\text { Selenium (Se) }\end{array}$} & \multicolumn{2}{|c|}{ Well 6-1 } & Well $6-2$ & Well 8-1 & Wel1 $37-1$ \\
\hline & $\begin{array}{r}40,000 \\
16,850 \\
3.0 \\
320 \\
5.45 \\
23,600 \\
8.8 \\
40.0 \\
1,050 \\
17.2 \\
.95 \\
14 \\
202 \\
42.8 \\
.99 \\
40.75 \\
2.75 \\
3 \\
.26 \\
5.5 \\
8,100 \\
1,360 \\
320 \\
9.75 \\
\text { ND }\end{array}$ & $\begin{array}{l}\text { Mmho } \\
\mathrm{mg} / 1\end{array}$ & $\begin{array}{rl}6,000 & \mathrm{mg} / 1 \\
2,142 \\
1.5 \\
269 \\
6.12 \\
5,000 \\
.10 \\
4.0 \\
150 \\
.24 \\
.05 \\
.25 \\
560 \\
156 \\
1.23 \\
14.7 \\
.38 \\
\mathrm{ND} \\
.22 \\
.90 \\
1,700 \\
16.4 \\
6.4 \\
7.45 \\
\text { ND }\end{array}$ & $\begin{array}{rl}3,200 & \mathrm{mg} / 1 \\
500 & \\
1.0 \\
389 \\
6.27 \\
1,600 \\
110 \\
i .1 \\
70 \\
\mathrm{ND} \\
\mathrm{ND} \\
.15 \\
417 \\
173 \\
1.6 \\
4.95 \\
.14 \\
\mathrm{ND} \\
.05 \\
1.2 \\
510 \\
8.5 \\
2.1 \\
1.6 \\
0.5\end{array}$ & $\begin{array}{r}4,700 \mathrm{mg} / 1 \\
510 \\
0.3 \\
274 \\
6.27 \\
2,900 \\
0.1 \\
0.6 \\
85 \\
\mathrm{ND} \\
\mathrm{ND} \\
.15 \\
845 \\
183 \\
1.42 \\
2.45 \\
0.2 \\
\mathrm{ND} \\
.025 \\
1.0 \\
730 \\
8.9 \\
1.4 \\
2.5 \\
1.8\end{array}$ \\
\hline
\end{tabular}

AFTER LINDEMUTH ET AL, SPE 6605 (1977) 
Imperial Valley waters are corrosive both downhole and on the surface. This will be a continual problem. Treseder and Wieland (SPE 6613) reported on early investigations of two 4,200 foot Shell 0il Company Salton Sea Geothermal Field wells, noting severe corrosion of carbon steel at the bottom of the well, a problem that has not been reported at The Geysers or in Wairakei, New Zeaiand. Higher temperature in the Shell wells $\left(6080 \mathrm{~F}\right.$ compared to $470^{\circ} \mathrm{F}$ and $518^{\circ} \mathrm{F}$, respectively, in the other two locations) were listed as a factor. And, as discussed earlier, Geysers' wells are vapor dominated. Treseder pointed out high salinity (12.7\% chloride ion) and presence of carbon dioxide and hydrogen sulfide as other-major factors-increasing the water corrosivity, Tables 2 and 3 show high TDS concentrations of the wells near the Salton Sea and effects of the corrosive water on various alloys.

\section{Flowing Mechanism, Downhole Flashing Problems}

The basic requirement is to achieve very high water flows, as the amount of heat to be "mined" from the underground source is proportional to flow. Since there is no expandable gas cap under the sealing rock surface, static pressure at the bottom of a well is a function of water height in the reservoir and average water density. In a"wellbore in which the water column has equalized to surrounding formation temperatures, the average density is high enough to exactly match reservoir pressure, and the fluid level is static, usually some distance below the surface (underpressured condition). When formation water is caused to enter the bottom of the well, colder water in the upper portion is displaced, and if it is removed, the average density of the coltumn 'is decreased and reservoir pressure then exceeds bottom hole wellbore pressure. The well then can start to flow and the hotter the wellbore fluid becomes, the lighter it becomes. The process will continue 
TABLE 2 - COMPOSITION OF RESERVOIR FLUID (PPM) FROM TWO SALTON SEA GEOTHERMAL FIELD WELLS*

\begin{tabular}{lrr} 
Constituent & No. 2 IID & No. 1 State \\
\cline { 2 - 3 } Sodium & 53,000 & 47,800 \\
Potassium & 16,500 & 14,000 \\
Lith1um & 210 & 180 \\
Barium & 250 & 190 \\
Calcium & 28,800 & 21,200 \\
Strontium & 440 & \\
Magnesium & 20 & 27 \\
Boron & 390 & 290 \\
Silics & 400 & \\
Iron & 2,000 & 1,200 \\
Manganese & 1,370 & 950 \\
Lead & 80 & 80 \\
Zinc & 500 & 500 \\
Copper & 3 & 2 \\
Silver & $<1$ & $<1$ \\
Rubidium & 70 & 65 \\
Cesium & 20 & 17 \\
Chloride & 155,000 & 127,000 \\
Ico & 500 & 5,000 \\
LS & 30 & 30 \\
Total Dissolved Solids & 259,000 & 219,500 \\
& &
\end{tabular}

TABLE 3 - CORROSION DATA FROM SAMPLES EXPOSED TO BOTTOM HOLE CONDITIONS IN A SALTON SEA GEOTHERMAL FIELD WELL*

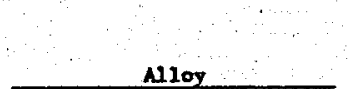

API Grade J-55 Steel

Type 410 stainiess steel

Honel 400

Inconel 600

Type 316L Stanless steel

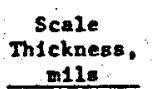

55.

55.

30.

19.

28.

\begin{tabular}{|c|c|c|}
\hline $\begin{array}{c}\text { Corte } \\
\text { We1ght } \\
\text { Logs }\end{array}$ & $\begin{array}{l}\text { Mon Rate, } \\
\text { Mepth PIt } \\
\text { Deth }\end{array}$ & $\begin{array}{l}\text { Crevice } \\
\text { Atteck }\end{array}$ \\
\hline 380. & 1000 & 500. \\
\hline 50. & n11 & 640. \\
\hline 25. & n11 & 90. \\
\hline 2. & n11 & n11 \\
\hline 0.5 & n11 & $n \neq 1$ \\
\hline
\end{tabular}

* FRON TRESEDER AND WIELAND SPE 6613 (1977). 
until pressure in the upper part of the hole decreases below the flash point of the superheated water. An uncontrolled well in this condition would blow steam and water at increasing ràtes and the flash point would move downhole until pressure on top of the superheated water column required to lift the wet steam exceeded the vapor pressure.

From steam tables, it is noted that 250 psi pressure is needed to prevent the flashing (boiling) of $400^{\circ} \mathrm{F}$ pure water. And water with high salt content would require even lower pressure to prevent flashing at $4000 \mathrm{~F}$. But disregarding the flashing mechanisms temporarilly in order to understand the effect of density change, consider this hypothetical example: If a 6,000 foot well is standing full of water with an average temperature of $200^{\circ} \mathrm{F}$ and that temperature is increased to $4000 \mathrm{~F}$, the height (volume) of the column of water is increased by $9.3 \%$, to 6,558 feet. Thus, this well that was initially static would flow a stream of water with 558 feet of head simply from being heated.

The principle applies in reverse in injection wells, or when lowering column temperature for controlling or killing well pressure. Low temperature injection water will be dense enough so that the column pressure exceeds reservoir pressure and water can be "poured" into the well on a vacuum, up to certain flow rates.

Well tests of several East Mesa wells illustrate some of the basic principles discussed above and the problems of scale buildup by flashing. Wel1 6-1 had a shutin BHP of 3,220 psi at 7,944 feet (a gradient of 0.405 psi/foot). Bottom hole flowing pressure was $2,337 \mathrm{psi}$, indicating an average gradient of 0.294 psi/foot. The downhole flash point was estimated to be at about 1,970 feet. Surface flowing pressure was about 25 psi at 15,000 bpd rates, 
including $16 \%$ steam. Mesa $6-2$ had 2,484 psi static BHP at 5,933 feet. It flowed 10,000 bpd with $7 \%$ steam under a restricted flow condition with a flash point at 335 feet. Surfâce temperature was about $270^{\circ} \mathrm{F}$ and flowing BHP was 1,970 psi.

Downhole flash points in East Mesa tests were determined by evidence of calcium carbonate scaling. Mathias notes "Some wells have shown a tendency to form $\mathrm{CaCO}_{3}$ deposits downhole at full flow operation. During testing of Mesa 5-1, sufficient deposit was formed to prevent lowering of smal1 diameter instruments". This well has a TDS of only $2,390 \mathrm{ppm}$.

\section{Productivity Index, Downhole Pumps}

Very high reservoir productivity indexes ( $P I=$ Barrels per day flow per psi pressure drop) will be required because of the low differential pressures between reservoir pressure and flowing bottom hole wellbore pressure. For example, to flow 50,000 bpd $(Q)$ with 200 psi differential pressure $(\Delta P)$, a PI of $250 \mathrm{bpd} / \mathrm{psi}$ would be required. Gulf Coast geopressured wells, for comparison, have PIs in the range of $10-50$ and require $\triangle P S$ of several thousand psi for high flow rates.

With a PI of '250, a drainage radius $\left(r_{e}\right)$ of 745 feet for 40 acre spacing, a well bore radius $\left(r_{W}\right)$ of 0.5 feet, and water viscosity of $0.2 \mathrm{cp}$, it can be calculated that: $k h=P I \ln \left(r_{\mathrm{e}} / r_{\mathrm{W}}\right) / 0.007087=(250)(0.2)(\ln 745 / 0.5) /$ $0.007087=57,549 \mathrm{md} \mathrm{ft}$.

Thus a well with average sand permeability $(k)$ of $100 \mathrm{md}$ would require 515 feet of net pay to be opened in order to flow 50,000 bpd at the pressure differential stated. To expose this much net sand with interbedded shale and silt layers, gross intervals of $1,000-2,000$ feet may have to be opened. 
Typical completion system to be explained later in this section will exemplify this requirement.

For increased production, primarily in areas where bottom hole temperatures are not high enough, natural flow is supplemented by downhole pumps. In typical installations, centrifugal (impeller) pumps are set at 1,000 feet. Natural flow lifts the water to that height with enough pressure to charge the pump and still not drop below the flash point. The pump then lifts the fluid to surface, still under pressure, and downhole flashing is prevented entire1y. The pressurized system is illustrated schematically in Figure 17. Such pumps"are modified water supply well pumps trimed for hot water service and powered by an electric motor on the surface and a vertical shaft that is stabilized and guided over its 1,000 foot length by Teflon type bearings. Investigation of ways to improve pump performance and increase bearing Tife in the severe environment is proceeding and practical solutions to problems with seais, etc. will be necessary-requirement for large scale development. Peerless Pump Company is one supplier of downhole pumps for the Imperial Valley geothermal well tests.

An integrated downhole pumping system that derives its own energy from the hot water has been proposed. This system, Figure 18, consists of a downhole impeller type pump that is connected directly to a steam turbine which, in turn, is powered by steam generated from fresh water (or another vaporizing liquid) supplied from the surface. The proposed system illustrated was developed by Sperry Rand Corp. Pump capacities of 1,000-1,500 gpm $(34,000-50,000$ bpd $)$ are claimed.

Another pumping system proposed by Sunstrand Corp. also would reduce limitations of the vertical shaft and increase depth capabilities by powering 


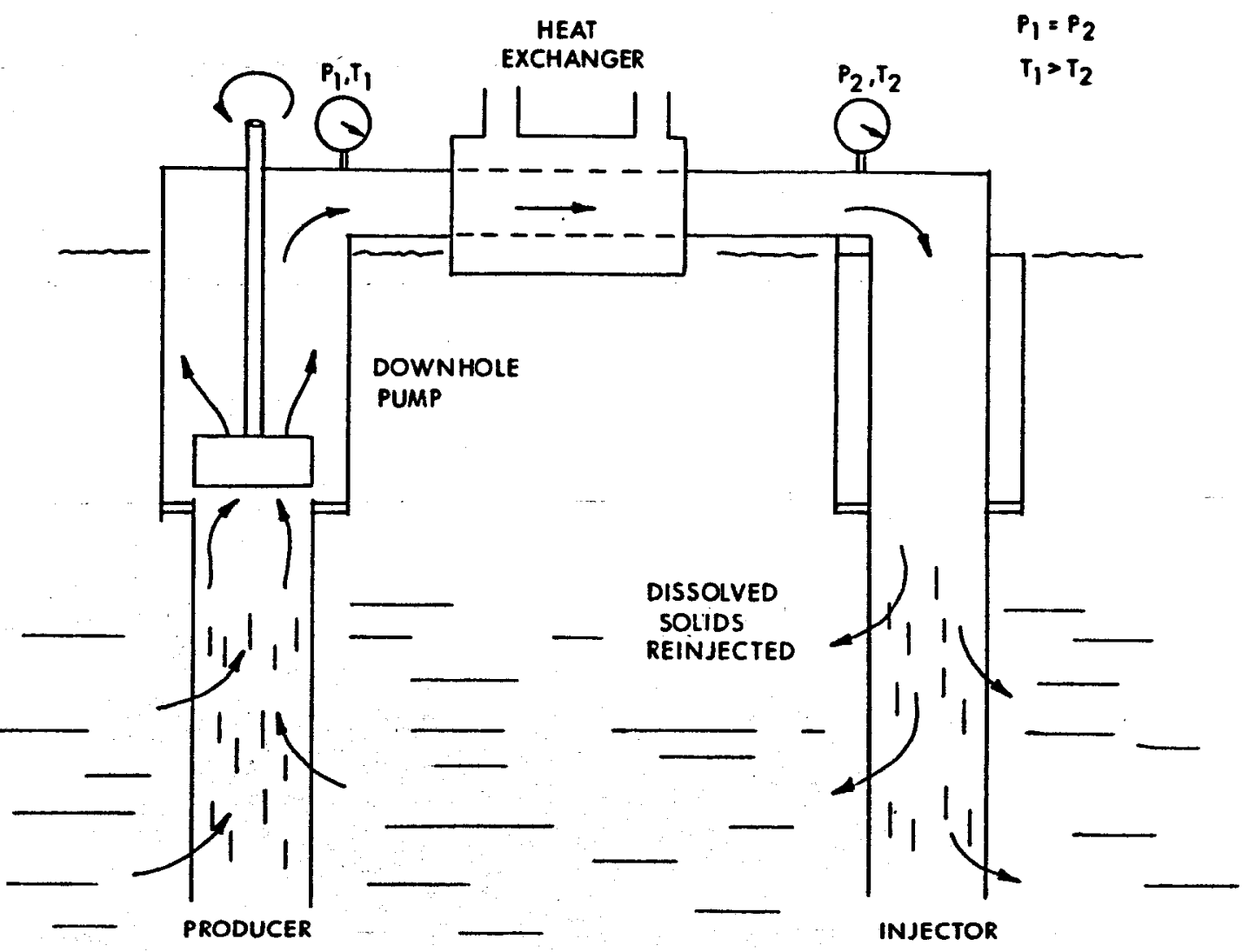

CLOSED, PRESSURIZED PREDUCING AND REINJECTION SYSTEM. DOWNHOLE PUMP ASSISTS NATURAL FLOW AND MAINTAINS WATER PRESSURE ABOVE THE FLASH POINT. SOLIDS ARE KEPT IN SOLUTION AND REINJECTED INTO THE PRODUCING RESERVOIR.

FIGURE 17 


\section{GEOTHERMAL DEEP WELL PUMP}

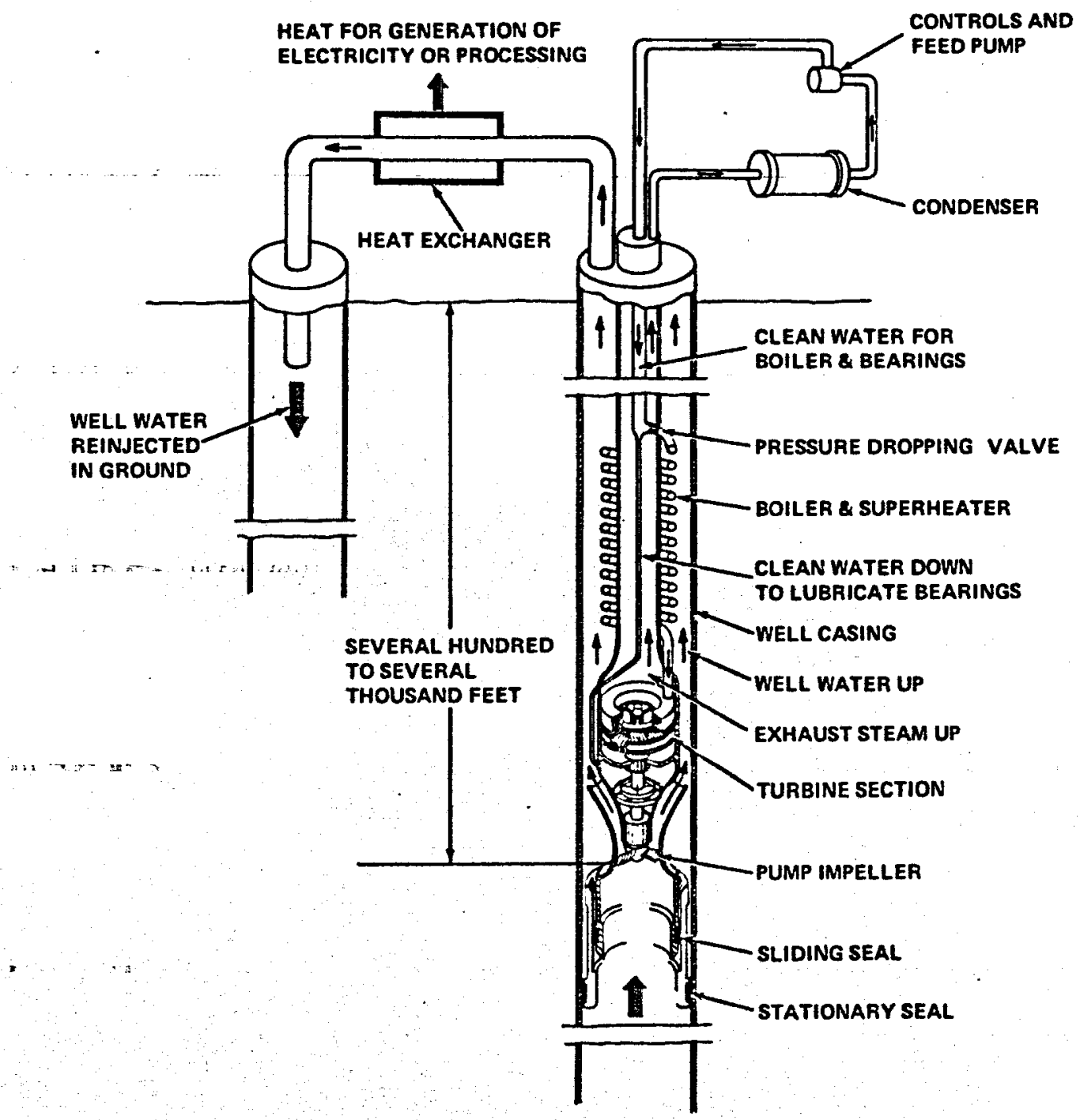

GEOTHERMAL PUMP DEVELOPED BY SPERRY RAND CORP. WOULD ELIMINATE VERTICAL SHAFT. CLOSED LOOP SYSTEM PREVENTS WATER FLASHING.

FIGURE 18 
the downhole pump with a directly coupled turbine driven by water pumped down tubing from surface, Figure 19. The turbine would exhaust into the main water stream to prevent need for a return line. This system would likely require that turbine feed water bè treated before pumping.

The heat recovery system shown in Figure 19 is binary, $i$. e. produced water heats a second fluid that actually does the generating work. The water disposal system shown does not maintain water pressure. Collecting ponds, particularly open pits, like the one illustrated, must be avoided to prevent three serious problems: 1) Scale precipitation, 2) Oxygen contamination, and 3) Surface dirt contamination from wind and dust.- Examples of problems with such systems at East Mesa will be discussed later in this section.

Development of a trouble free high volume lifting system for the Imperial Valley is critical to program success. The pumping systems discussed above all rely on complicated, moving equipment, that must operate in very severe downhole environments. One alternative that has not been widely discussed, if it has been seriously considered, is application of gas lift. A recomendation for investigating this method will be submitted in a separate report.

\section{Formation Stress Factors, Perforating vs. Slotted Liner}

Imperial valley wells are all cased, as downhole formations are not competent enough to permit open hole (bare foot) completions. However, general use of uncemented slotted liners with wide slots makes completions as close to open hole types as it is possible to obtain, without the hole caving in. 


\section{BINARY GEOTHERMAL SYSTEM}

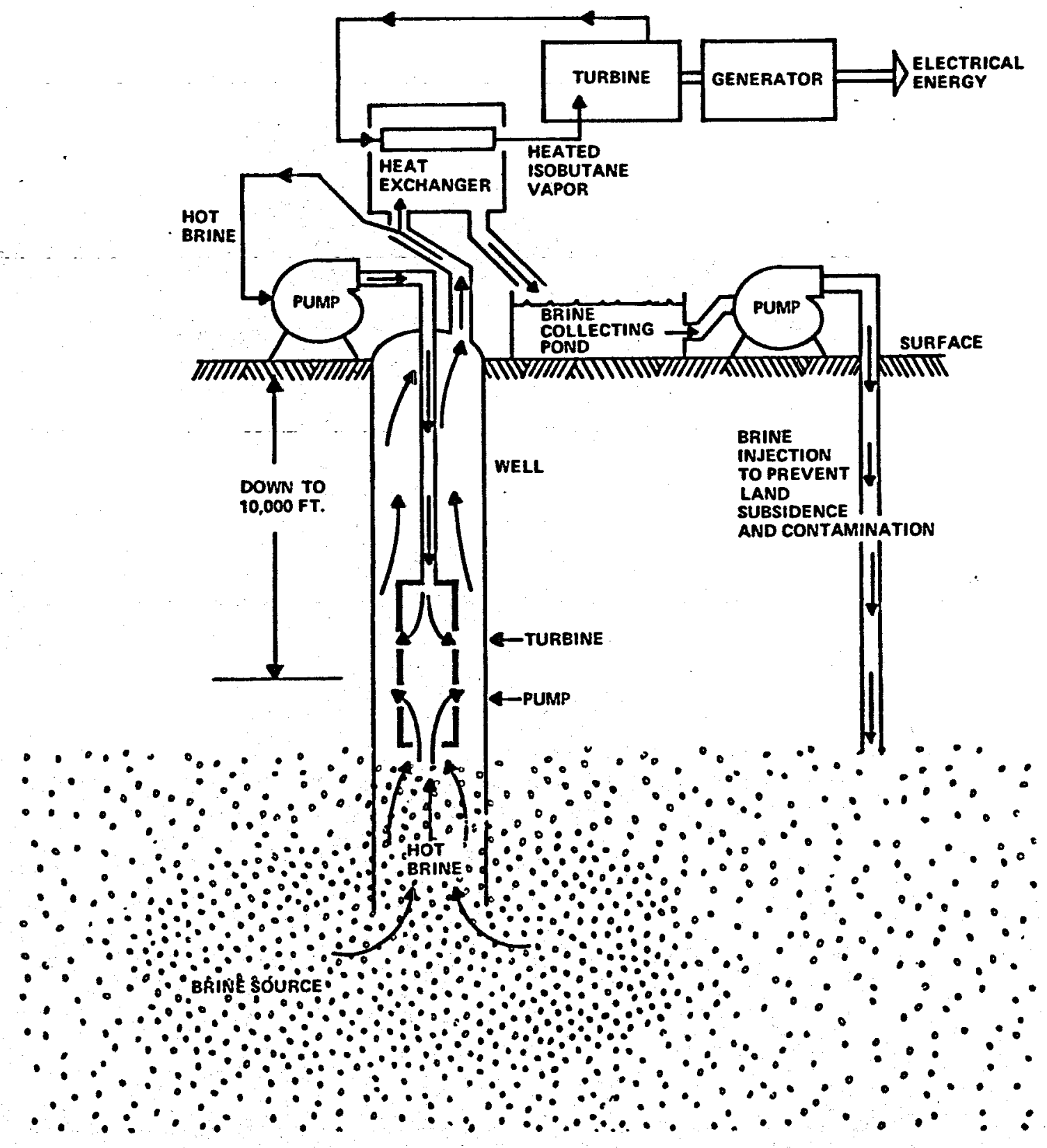

GEOTHERMAL PUMPING SYSTEM PROPOSED BY SUNSTRAND CORP. POWERS THE DOWNHOLE PUMP BY PRESSURIZED WATER. 
One operator cements and perforates casing across the producing zone. This operator claims to have few problems with production of reservoir fines and sand. And when problems occur, it will be possible to isolate zones in the cemented and perforated casing for individual treatment.

It might also be extrapolated from this comparison that the cemented casing provides necessary formation support that prevents movement of the wellbore, and sand dilation, that could lead to long term sand influx problems. An extension of this concept would be use of the Completion Technology Co. Pack Perf Completion System in which an external casing packer is located across the sand and the rubber element is pumped full of cement slurry at calculated pressure, to stress the wellbore, Figure 20 . Perforating through the set cement and packer element provides the necessary flow chanels for production. Such packers are presently limited to 20 foot maximum lenths and no application has been tested in geothermal conditions. Performance of the rubber element in high temperatures can logically be questioned. However, in this application, the elastomer is contained under stress between cement and the formation and continued cure hardening of the rubber should not be a limiting factor.

Improvement of slotted liner installations for sand control and reduced productivity impairment by open hole gravel packing will be discussed later in this section.

Completion Methods, Casing-Liner Programs

A typical slotted liner completion program for a 7,500 foot well would have 90 feet of 20 inch conductor cemented in a 26 inch hole; 1,500 feet of $13-31 / 8$ inch, $K-55,54.5 \mathrm{ppf}$, Buttress thread surface pipe cemented to surface in $171 / 2$ inch hole; and 4,000 feet of $85 / 8$ inch, 32 ppf, K-55, 


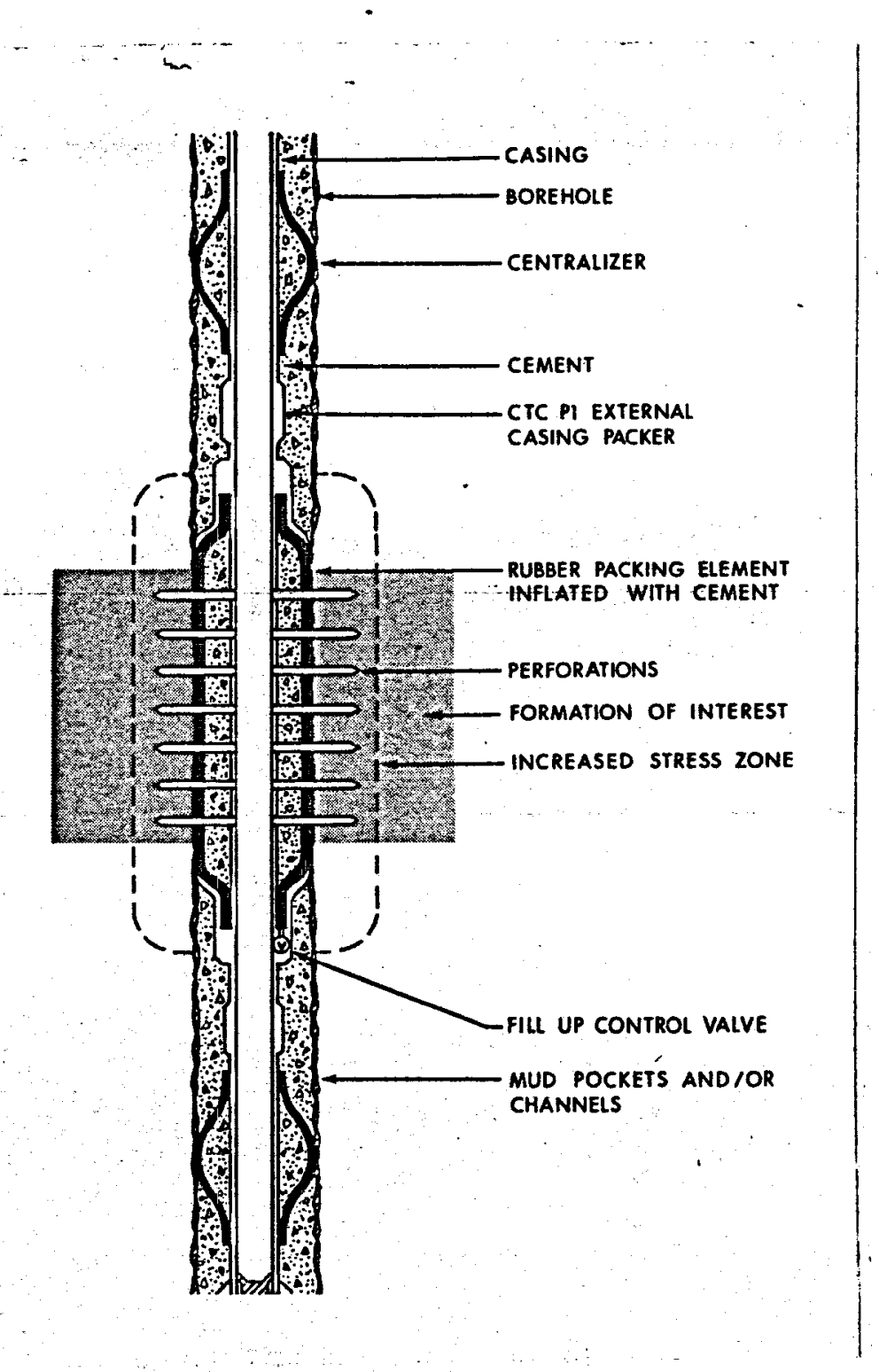

PACK/PERF COMPLETION SYSTEM OFFERED BY COMPLETION TECHNOLOGY COMPANY MAINTAINS STRESS ON BOREHOLE WALL TO PREVENT FORMATION MOVEMENT AND START OF SAND FLOW.

FIGURE 20 
Buttress thread liner would be hung 200 feet into the surface pipe then cemented and squeezed, if necessary, see figure 21 . The hole then would be completed to 7,500 feet using a $77 / 8$ inch bit, and, after logging, 2,400 feet of $65 / 8$ inch, 27.65 ppf, K-55 flush joint liner with up to 0.25 inch wide milled vertical slots would be run and hung 200 feet into the $85 / 8$ inch using a lead seal type hanger.

The slotted liner then would be cleaned out with a California style pressure wash tool commonly used in San Joaquin Valley oil well completions and drilling mud would be flushed out with $\mathrm{KCl}$ water or $\mathrm{NaCl}$ brine. Figure 22 illustrates wash tool use.

The BOP's would be removed from the master valve, which was installed on the surface pipe, as in The Geysers. And with the second master valve and flow equipment installed, the-werl-would be ready for clean up and testing.

The new well may or may not flow initially (note comparison with Geysers live steam completions) due to the cold water column in the casing. Wells can be stimulated to flow by running continuous tubing through a lubricator on the flow tee and injecting nitrogen to lighten the top of the column.

Initial flow into settling tanks reportedly flushes out mud lodged between liner and wellbore fact and filter cake that the wash tool missed.

It is common practice to test wells for extended periods and, if additional productivity is needed, perforate additional sands behind the cemented liner, as recorded by the open hole logging program. Such sands must be below the level of the minimum acceptable isotherm.

Note that several wireline tools are utilized in these completions including logging sondes and perforators. And, elastomer packing elements are used on treating packers, cement retainers, etc. These tools can be utilized 


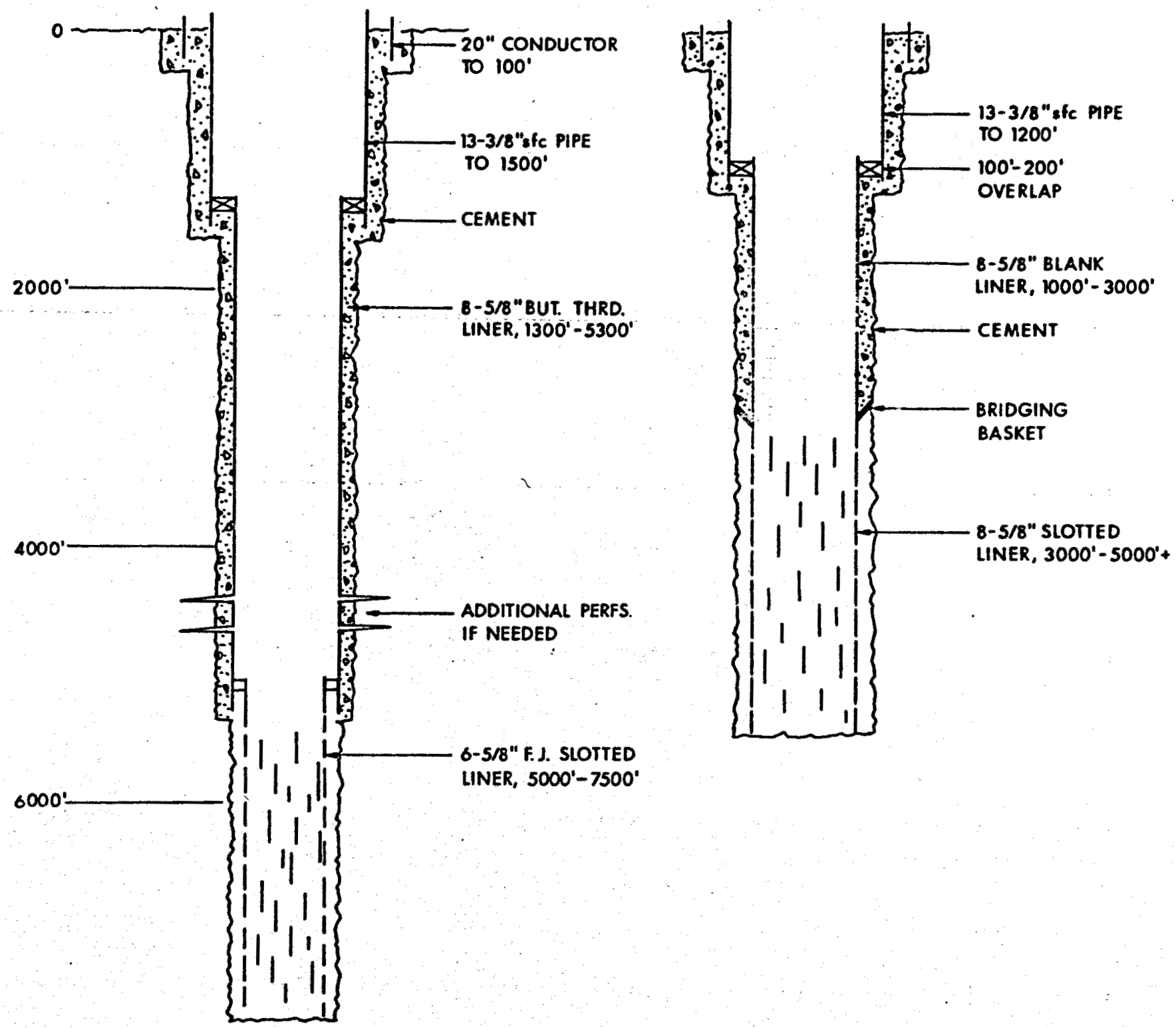

$8000^{\prime} \longrightarrow$

TYPICAL IMPERIAL VALLEY COMPLETIONS FOR TWO WELL DEPTHS. FULL CASING STRINGS OR TIE BACK CASING WOULD BE REQUIRED AS TUBING FOR INJECTION WELLS. LARGE DIAMETER SURFACE PIPE IS NEEDED FOR DOWNHOLE PUMPS.

FIGURE 21 


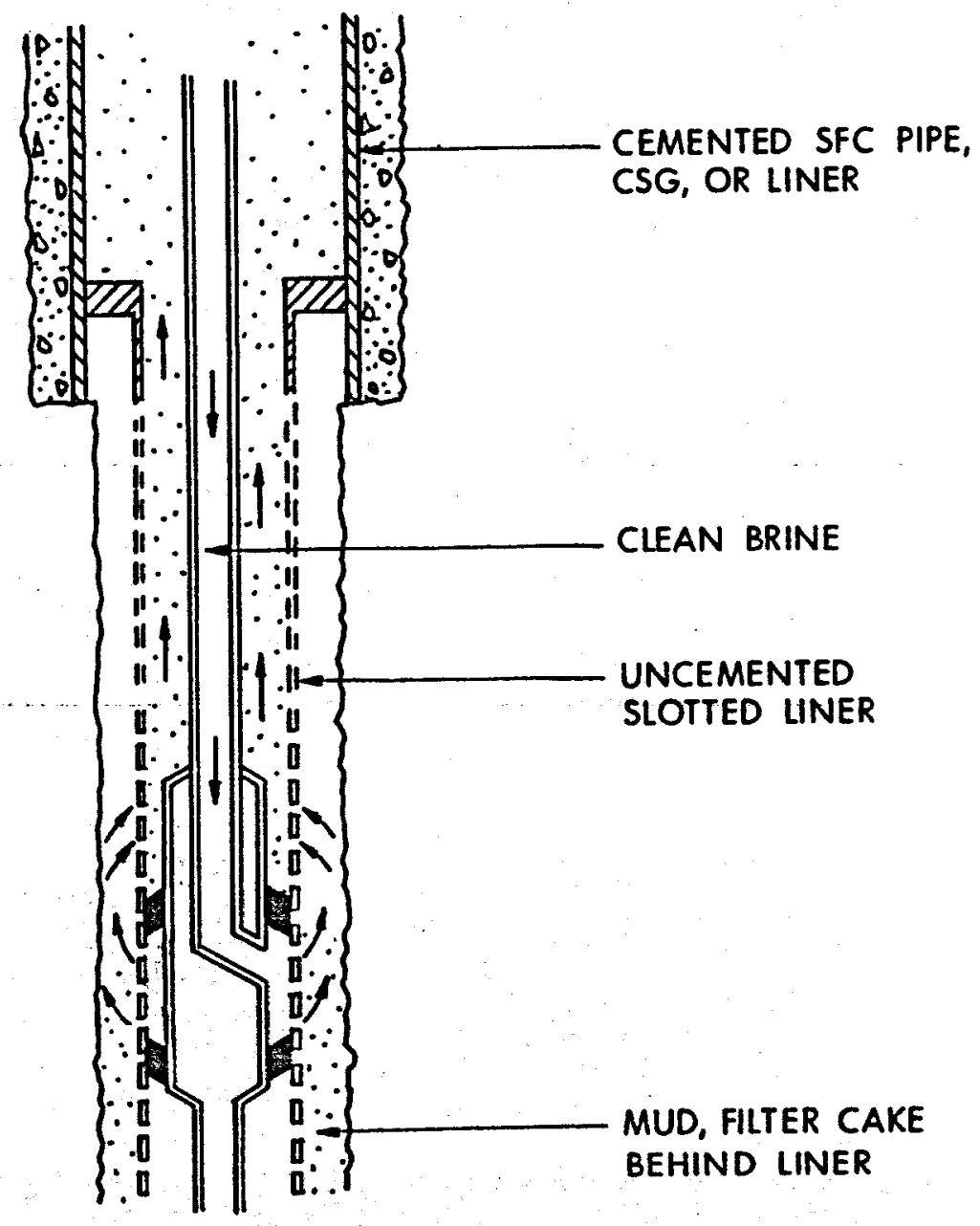

SCHEMATIC OF CALIFORNIA STYLE WASH TOOL BEING USED TO DISLODGE DRILLING MUD FILTER CAKE FROM BEHIND LONG SLOTTED LINERS. CLEAN BRINES ARE USED TO DISPLACE MUD IN NEW WELLS.

FIGURE 22 
for short periods because the cooled circulating mud system provides a workable environment. Few of these tools would operate reliably at existing bottom hole temperatures for any great length of time.

Another completion program for shallower wells consists of 1,000 feet of $133 / 8$ inch surface pipe, into which is hung 5,000 feet of $75 / 8$ (or perhap $85 / 8$ inch) liner, see Figure 21. The bottom of the liner may be siotted over 500-2,000 feet and the rest left blank. A bridging basket and stage collar allows cement to be placed in the blank liner-wellbore annulus, leaving the slots open. Again, additional zones may be opened by perforating the blank iiner.

Both of these completions leave about 1,000 feet of large diameter casing at the top, into which 12 inch diameter downhole pumps can be run.

Hydraulic stimulation and acidizing are not widely utilized to improve flow rates. Long sections of foosely cemented sands do not fracture like harder rocks, and propping materials embed easily. And without effective zone separation it would be impossible to selectively inject into tighter sands to attempt to create deep, artificially propped fractures. One operator does pump into new wells at highest attainable rates using canal water, and improvement is claimed. This procedure likely removes some skin effect and displaces some particles away from the critical small diameter wellbore. However, any water pumped into sand formation should always be checked for compatibility and turbidity. Clay swelling and particle plugging in lower permeability zones can severely damage productivity.

Acid clean outs must be applied with caution, as inhibitors to protect tubular goods from conventional $\mathrm{HCl}-\mathrm{HF}$ type acid as it is being displaced are ineffective above $275^{\circ} \mathrm{F}$. Normal7y, to use acids, the system is first cooled to below $275^{\circ} \mathrm{F}$ by circulating fluids. 
Mud, Cement

Fresh water gel-lignite drilling muds are commonly used. The lignite is a thinner to prevent caking and bridging. Normal weights are 70-75 $\mathrm{lbs} / \mathrm{cubic}$ foot (9.5-10 ppg). Mud weight is needed for hole stability, not formation pressure control. Cooling towers are commonly used to keep mud temperatures below $200^{\circ} \mathrm{F}$. Sepiolite (Thermogel) is a promising fluid for hotter wells and seems to stand 4000F temperatures better than gel-lignite. Foam and air cannot normally be used in these holes because of the high water flows and hole stability problems.

Surface pipe may be cemented with 1:1 API Type G and Perlite with $2 \%$ ge7, $35 \%$ silica flour and $0.5 \%$ CRF-2, tailed in with neat cement with silica for high compressive strength. Liners are cemented with the same composition. Cool water preflushes are used along with retarder to prevent premature setup. Depending on temperatures, retarders should allow three hours pumping time.

Research should be initiated on existing cement compositions, to extend strength retrogression with time data into geothermal environments-perhaps up to $650^{\circ} \mathrm{F}$. New compositions may be required to assure reliable, long life protection for large diameter casing strings used in geothermal developments. Operators and regulatory agencies should be aware of geothermal cementing limitations, and effectiveness and economics of alternative programs.

\section{Sand Control, Non-Damaging Fluid Application}

Long term production has not been possible without plant installation so reservoir performance regarding sand influx at sustained high flow has not been defined. However, reports of significant skin effects (productivity impairment around the wellbore) and evidence of sand production on initial 
flow indicate the potential for long range sand problems, as explained below. Sands containing clays are usually sensitive to flow of incompatible (fresher) waters. The clay particles swell and djsperse, and lodge in smaller flow channels between sand grains. The swelling is partially reversible, but dispersion plugging is difficult to remove. Movement of the formation as the borehole wall rearranges around an unpacked slotted liner aggravates the plugging mechanism and the result can be severely reduced permeability around the liner. And, any beneficial bridging of sand grains across the liner slots may only be temporary.

..The reduced permeability zone causes excessive pressure drop across the skin where radial flow is already restricted by the converging effect of a large reservoir flowing into a small radius wellbore. And high velocity flow created by the restriction can efode liner slots, allowing even greater-volumes of sand to be carried in. The pressure drop can also be great enough to cause scale precipitation on the formation face on in liner slots.

To avoid these problems where high productivity of an open hole is desired with minimum pressure drop at the point of entry into the wellbore, open hole gravel packs around slotted liners or screens may be required. Available techniques are fairly well known for California type oil and gas wells. An ideal job for an Imperial Valley geothermal well may proceed as follows:

1. The open hole pay zone would be underreamed to positively remove drilling mud filter cake and to enlarge the borehole for improved radial flow. The mud filter cake should be removed with a properly designed completion fluid containing suitably sized bridging material, to minimize particle invasion and to maintain hole 
stability. One such available fluid contains calcium carbonate bridging material for the sand faces and polymer that promote shale stability. $m$

2. A liner with properly designed and sized slots would then be run and the enlarged hole would be packed by pumping in gravel (actually larger diameter sand). Slot size and gravel diameter are designed from sieve analysès of formation sand to be supported Typical California oil field sands have a wide size distribution, with a 50 percentile median diameter of perhaps 0.01 inch. And accepted slot sizing techniques (twice the 10 percentile diameter) call for slots of about 0.08 inch width. Sieve analyses for Imperial Valley wells are not available but it would appear that slots reportedly as wide as 0.25 -inch may be too large.

3. When the well is placed on production, the carbonate bridging material, if properly sized, will produce back through the highly permeable gravel pack. And the formation will be supported by the pack to prevent movement. Only movable fines should penetrate the pack and larger grains will form stable bridges. The pack can be washed with a weak acid solution to assure complete carbonate and polymer removal.

Such installations may be costly for long intervals in the Imperial Valley but they still may be more economical than regular well repair for sand control or scale removal, and they certainly would be cheaper than drilling additional wells to obtain required productivity. Gravel packs can require additional special techniques in high angle holes (over 500 ) if directional drilling is planned. Also, the effects of high temperatures on the polymers used in non-damaging fluids would have to be investigated. 
Fluid Handling Systems, Injection Problems

Imperial Valley wellheads, as mentioned, are nearly identical to those used in The Geysers. However, -temperatures can be higher, metal surfaces are always wetted and scaling is a major problem.

Flowing water or wet steam tends to increase casing (tubing) elongation more than dry steam at the same temperature (a friction factor effect), so expanding wellheads may be used to a greater extent in the Imperial Valley. Also, because hot water wells can be controlled (killed) relatively easily with liquid systems, there will likely be more downhole work and thus more cyclic thermat stresses on downhole tubulars and wellheads.

Restrictions, shoulders, or projections that can create eddy currents in the flow stream are likely places for scale buildup to start. This was proved conclusively in Cerro Prieto operations in which heavy scale deposits formed downhole at points of casing diameter enlargement.

During flow tests of new hot water or wet steam wells, a steam separator is used to isolate the two phases for volume and heat measurements. A wet steam producing field, of course, would require permanent use of separators at each well. In Cerro Prieto, for example, the steam is separated and utilized in turbines and the water is discarded. W-K-M Wel lhead Systems, Inc., is one supplier presently offering all equipment required for a geothermal surface installation. That company claims its separators can deliver 99.8 quality steam.

Injection problems have not been clearly defined in the Imperial Valley. It has been proved conclusively in the East Mesa project that injecting flashed and cooled water creates several undesirable conditions. Transfer lines and the injection/disposal wellbore were severely plugged in early tests. 
The following summary of actual operations of the Mesa 5-1 injection well clearly illustrates the basic problems to avoid: The well had 1,000 feet of slotted liner opposite sand with $69 \mathrm{md}$ permeability (by Schlumberger Saraband). Injection water from the holding pond had $50,000 \mathrm{ppm}$ TDS, a pH of 7.5 and $6.5 \mathrm{mg} / 1$ dissolved oxygen. The well's fluid level was below surface before starting injection, $i$. e. the well took water on a vacuum. Within 48 hours, at 6,300 barrels per day, pressure was required and within 10 days the well would take only 2,500 bpd at 80 psi. Analys is showed the water contained $0.0923 \mathrm{~g} / 1$ suspended solids which were found to be quartz and clay that was blown into the open pit by the wind. It was estimated that over one ton of such foreign matter was injected in this brief test in which only 72,000 barrels were handled. When the downhole wireline instrument was pulled, the lower end of the line was severely corroded due to the dissolved oxygen.

One operator is testing a method in which water is to be treated in steel settling tanks with flocculants that will filter out precipitates before they enter the injection system. The residue would be periodically dried and hauled to an acceptable dump site. But the most practical scheme still appears to be pressure control of the water and prevention of oxygen contact throughout the entire system.

Injection problems must be solved. The development of large multiwell production systems around generating plants will require reservoir recharging to maintain heat reserves. Long range goals for the Heber area, for one example, call for up to 6 million barrels/day of production and a correspondingly large peripheral injection system. Project economics will dictate lowest possible operating and maintenance costs. 


\section{HOT, DRY ROCKS}

Practical application of the concept of recovering heat from deeply buried hot rocks by circulating water is perhaps years away. The federal government is apparently sponsoring all investigative efforts at this - time and if any privately funded projects have drilled deep wells into hot, dry rocks it was probably unintentional and the result of missing a geothermal water or steam target due to a geologic anomaly.

Because of the severity of specialized drilling and completion requirements in the volcanic geologic provinces that are the most attractive heat sources, and very nebulous economics for private development, it is difficult to see significant industry involvement in any manner other than through federal contracts.

Thus, it is safe to predict long development times for equipment and services that will be required, if modified oil field techniques not applicable to other geothermal projects are requested. It was very recently that suppliers of geothermal equipment described earlier in this report realized a significant market potential to justify expanded research and development. And that market is still only attractive on an international scope.

One sure way to rapidly improve the broad technology needed to develop a significant dry rocks energy recovery program is for the federal government to subsidize or outright purchase the energy product at a price that will attract competitive industry participation. And then it must open enough prospects through large scale leasing programs so that major energy producing companies can justify $R \& D$ costs. 
Definitions, Project Background

The history and status of dry rocks development is well documented in several reports published by Los Alamos Scientific Laboratory of the University of California. This organization, under Department of Energy (formerly ERDA) funding has conducted most of the investigations. Two major progress reports are listed in the references, see Blair and McGetchin.

There are two broad classifications of hot dry rocks (HDR): 1) Igneous related--that with heat transferred upward from buried magma bodies, and 2) Crustal heat--that conducted outward from the earth's deeper interior in a localized "hot spot".

The latter category has the broadest application because it exists everywhere to a certain extent. But initial tests have zeroed in on the first category because it is much easier to find hot rocks around extinct volcanos and because exploration methods to find deeply buried heat are not as advanced as conventional techniques for locating sedimentary traps.

Exploration and site selection is very difficult and it is still in the early stages of development. HDR also exists around, or in conjunction with vapor or water dominated zones. Deep fracturing or faulting could completely alter the target zone characteristics. The present formation properties being sought are heat and impermeability.

To be able to pump water into one well and back up another, the rocks must have negligible matrix and fracture permeability. If if the zone is highly fractured and connected to a major water source, it could be commercial as a steam producer. In between these two conditions, project economics May depend on the amount of leakage in the downhole "heat exchanger". Three HDR projects are under evaluation: 1) The Valles Caldera 
deep drilling project in New Mexico, 2) the Coso Spring, California, slim hole drilling evaluation, and 3) the Marysville, Montana, deep well. The Valles Caldera project is the primary subject of this report.

Coso Springs project goals are to develop slim hole drilling exploration techniques and to assess potential of the area. The site is in the mountains, 80 miles east of Bakersfield, within the Coso Springs KGRA. It is located over a magma intrusion and there are numerous hot springs and fumeroles in the area. HDR evaluation began in 1974. Experts believe pinpointing of attractive HDR sites will depend on heat flow analyses that are best obtained in shallow wells, so the effort will be an important contribution to HDR exploration capability. The project, however, is not concerned with well completions and will not be discussed further in this report:.

Marysville, Montana, Project

This site, located 20 miles northwest of Helena, was selected by Battelle NW Laboratory to test the hypothesis that molten rock exists within a "few kilometers" of the surface. In 1974, a well was drilled to a TD of 6,790 feet using aerated water for much of the drilling. This well was not successfur in finding hot dry rocks. It was a valuable milestone in the learning process. And it proved that more reliable HDR exploration techniques are needed, particularly slim hole heat flow tests--which were not used in this project to develop pre-drilling models.

Two major formations were drilled, the Empire Shale (metamorphosed shale and quartizite) to 975 feet, and the Empire Stock (porphryritic to nonporphryritic granite) 975 feet to TD. - Large volumes of water were found in extensive fracturing, but maximum temperatures were less than $2120 \mathrm{~F}$. Numerous shallow water flows that were encountered tended to flow down the hole indicating very low bottom hole pressure. 
The well was cased with 20 inch conductor to 115 feet; $133 / 8$ inch, K-55 surface pipe to 1,326 feet; and a $95 / 8$ inch, K-55 Tiner hung in the $133 / 8$ inch, was landed at 4,264 feet and cemented. A $77 / 8$ inch open hole was drilled from 4,264 to 6,790 feet TD. A 9 5/8 inch tie back string was landed in the liner hanger and extended into an expanding type wellhead; this string can be removed when the well is abandoned.

Despite low temperatures, local service companies had difficulties logging, coring and cementing the well. Fractured zones and water flows and the absence of a properly conditioned mud system likely contributed to cement placement problems. Logging crews "regularly encountered problems that made it difficult to obtain reliable data". Coring was difficult and costs are estimated at $\$ 11,000$ per recivered foot. Additional HDR drilling at Marysville is not planned. Project results again tend to point out need for a specialized technology for completing wells in hard, fractured rocks.

\section{Valles Caldera Project Goals, Progress}

Caldera is a Spanish word for caldron or boiler, and the term is used to describe the large crater formed by a collapsing volcano. It is significantly-larger in diameter than the volcano's vent. The magma intrusion under the caldera creates a ring fracture pattern of highly disturbed igneous rocks, see Figure 23. The plan in the Valles Caldera project was to drill as close to the magma as possible and stay outside the ring fracture zone to find solid granite rocks. This site selection concept was proved valid.

At the site, twenty miles west of Los Alamos, New Mexico, side by side wells were drilled to 9,619 feet and 10,053 feet, respectively, into a large block of impermeable granite on the western flank of the extinct volcano. 


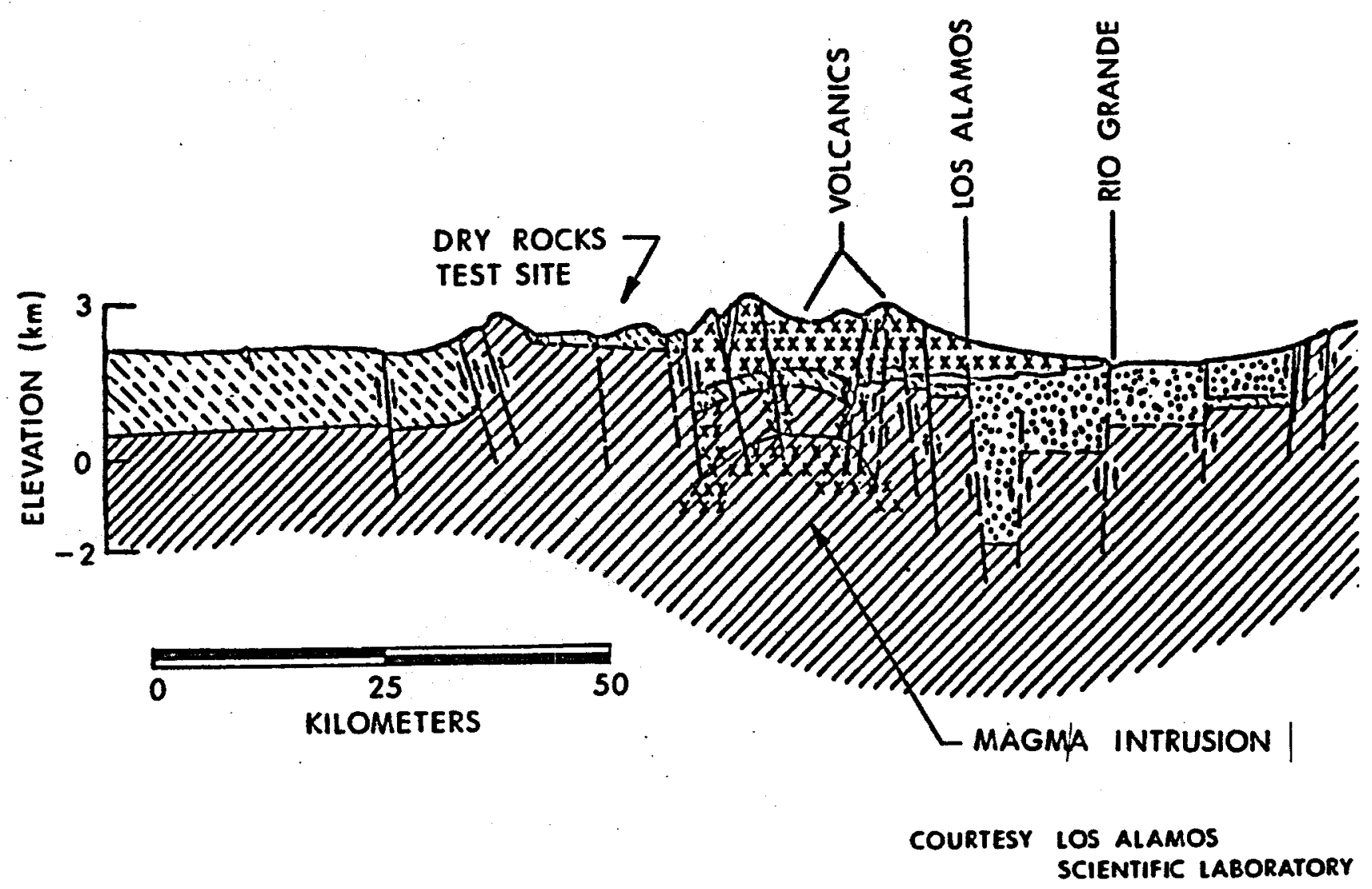

VALLES CALDERA, NEW MEXICO, GEOLOGIC CROSS SECTION CONCEPT SHOWS HOT MAGMA INTRUSION THAT CREATES A RING FRACTURE PATTERN IN CRYSTALLINE BASEMENT ROCKS.

FIGURE 23 : 
Drilling was started in 1974 and well experiments and further evaluations have continued from that time.

A vertically oriented hydraulic fracture was created in the first well, GT-2; and the second well, EE-1, located some 200 feet away on the surface was directionally drilled so as to intersect the first fracture. The object was to create a system with an extensive heating surface through which water could be circulated, Figure 24 : A surface heat exchanger will be, installed to conduct heat recovery tests. Target temperatures of $200^{\circ} \mathrm{C}$ $\left(392^{\circ} \mathrm{F}\right.$ ) were desired. And a 1972 slim hole test (we11 GT $=1$ ) to 2,576 feet indicated such temperatures could be reached, and in rocks that can be hydraulically fractured.

Actual BHT was $3870 \mathrm{~F}$. Measured permeabilities were about one microdarcy. The first fracture was apparently not intersected by the second well as limited communication was established. Even after fracturing the second well, communication improved only moderately, as the fractures were judged to be parallel. The difficulty was reportedly not an inability to directionally drill from an operational standpoint (a mud operated Dyna Drill was used with some high temperature complications). The problem was in accurately monitoring deviation and azimuth during drilling; and defining fracture orientation.

In the spring of 1977, GT-2 was directionally redrilled to connect with a fracture produced in EE-1. The attempt was successful and cold water pumped down EE-1 at 1,000 psi was recovered at temperatures of $266^{\circ} \mathrm{F}$, with only 15\% 10ss. This performance is expected to improve. A 10 NW recovery system was scheduled to be operational in late 1977. If successful, it may be enlarged to $100 \mathrm{MN}$. 


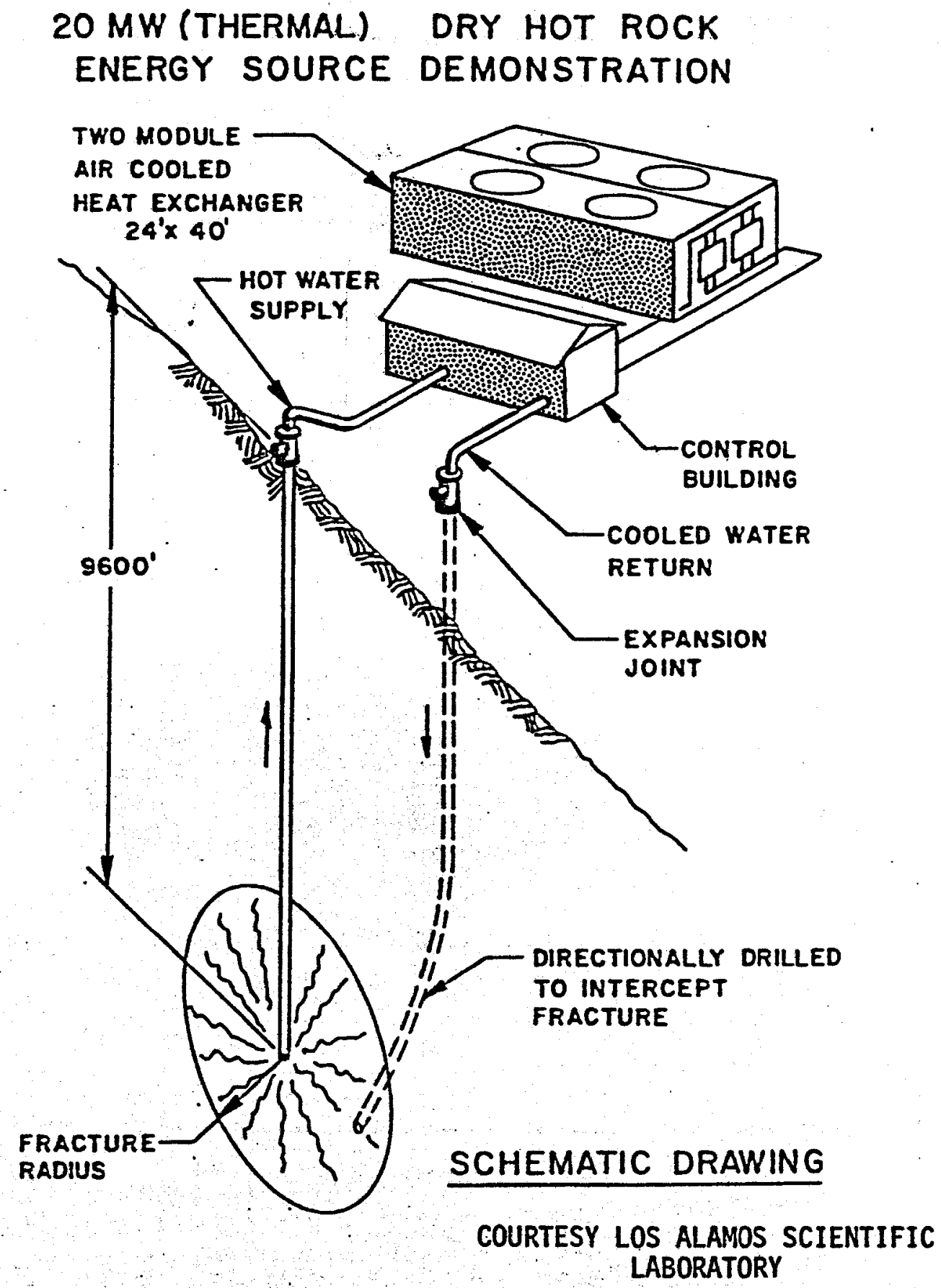

HOT, DRY ROCKS HEAT RECOVERY CONCEPT. DOWNHOLE FRACTURE SYSTEM REQUIRES IMPERMEABLE ROCKS SO THAT CIRCULATING WATER IS NOT LOST. .

FIGURE 24 


\section{Discussion of Operations}

Casual review of the detafled reports on drilling, completion and testing of wells GT-2 and EE-1 could lead to the premature conclusion that the project was fraught with so many difficulties that a useful technique has not been demonstrated. However, considering the fact that the program from start to finish is experimental and that over one hundred sophisticated tests interrupted normal drilling and completion sequences, the results are actually quite impressive. One is left with the impression that, taking away the hordes of scientists probing and measuring downhole every few feet, the basic takksof drilling, casing and fracturing could have proceeded quite rapidly and with fewer problems.

The project is also lengthy, already extending over three years to match DOE-funding arrangements. The hot, dry nature of the holes allows this type of extended experimentation without major well control problems (large volumes of steam or pressurized hot water). And the formation is not sensitive to damage by extended exposure to liquids that cause plugging, clay swelling, etc. The bored holes in solid granite will be there forever without sloughing or caving.

When testing progresses to the circulation of water, the producing wel. will of course become a live well and maximum precautions will have to be taken to handle $380-390^{\circ} \mathrm{F}$ water and/or steam.

Actual drilling was not reported to be a significant problem after caving sedimentary rock in the upper hole was cased f see formation log and temperature gradient curve, Figure 22). Air drilling was desired so /that una 7 tered rock temperatures could be measured, but longer bit runs were made with water so air drilling was discontinued. Bits were standard hard 


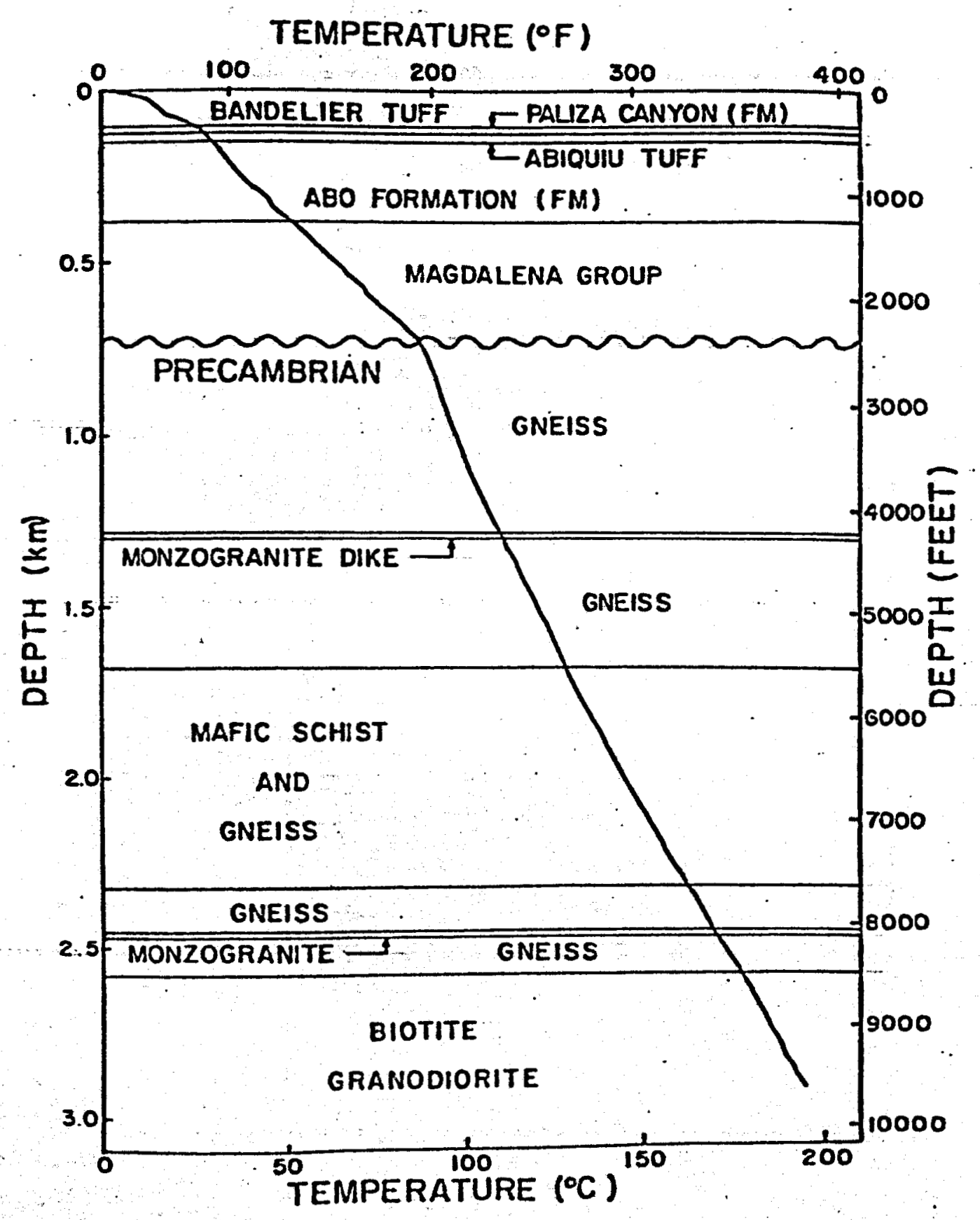

COURTROY LOS ALAMOS

SCIENTIFIC LABORATORY

FORMATIONS AND TEMPERATURES ENCOUNTERED IN VALLES CALDERA DRILLING OPERATION. NATURAL FRACTURES IN GRANITE ARE MINERAL SEALED.

FIGURE 25 
rock mining bits fitted with open, fluid cooled and flushed hardened bearings designed for air or mud. Smith 9JS bits, for example, lasted about 300 feet or 60 hours. Extensive coring was done using a JOIDES type wire line retrieva- $\checkmark$ ble core barrel and insert type bit (used in offshore sea floor coring), and Christensen diamond bits. Diamonds generally gave better recoveries but shorter bit life. Bit gauge wear and bearing life performance at temperatures up to $390^{\circ} \mathrm{F}$ were not considered a major problem, although improvements would be desirable, and probably necessary, for higher BHTs.

Hydraulic fracturing and hydrology experiments were conducted at several depths in GT-2. Open hole Johnston DST type solid rubber packers were used extensively, also Lynes inflatable packers. The packers were set over a desired test interval with dual rubbers above and below, and permeability tests were run before the granite was hydraulically fractured by $1,000-1,500$ psi surface pressure (plus hydrostatic head in the drill pipe). These tests proved that the granite could be fractured and that permeabilities were very low (one microdarcy), allowing over $90 \%$ of frac fluid recovery. The fractures tended to self prop but they could also be plugged with drilling fluid and did not always reopen with pressure. Fracture orientation was vertical as proved by later impression packer runs.

Solid rubber packer elements were sometimes torn during operations in the rough, hard hole and hook wall types were sometimes difficult to set. Temperatures up the hole were not excessive for rubber packer use.

A 210 foot section of 7 inch, 20 ppf casing was cemented in a $95 / 8$ inch open hole at 6,501 feet, with a flared packer bore receptacle in the top. Frac tests were conducteditin this scabaliner using packers across perforations. This liner then was washed over and removed. 
A longer; 608 foot, $75 / 8$ inch $O D$ scab liner then was cemented in the hole from $9,581-8,973$ feet and fracture evaluation tests were conducted in the open hole above. An Otis packer was set prematurely in this liner due to a constriction in the casing. This packer leaked and it was subsequentiy milled out and removed, perforating the liner in the process. It was later discovered that the packer leaked enough water so that the open hole below the liner had been fractured during one pressure test operation. Eventually, spinner tests indicated fractures were created through the liner damage at 9,220 feet as well as in the lower part of the hole. The final casing program for GT-2 is shown in Figure 26 ?

During later GT-2 tests, EE-I was drilled and fracture tests were conducted with prototype downhole seismic instruments emplaced in the GT-2 borehole. Then the target fracture was created in the bottom of GT-2 with 12,000 gallons of pumped fluid, while observing seismic signals in EE-1.

Directional drilling in EE-1 was designed to guide the borehole toward the GT-2 fracture. However instrumentation proved inadequate to both define the path of the first well and its fracture orientation, and to guide directional drilling while it was in progress. Magnetic surveys were unreliable in the volcanic rocks and gyroscopic instruments did not tolerate high temperatures. The EE-1 casing program is shown in Figure 26.

A fracture was created in EE- 1 and communication between wells then rèquired a very high 200 psi per gpm: A deep section of EE-1, below 9,791 feet, would not fracture at 3,300 psi wel thead pressures.

The program was to be continued by redrilling the lower part of one of "the wells to intersect the fractures of the other well. This was done in 1977 as noted earlier. Details of the later operations were not available for inclusion in this report. 


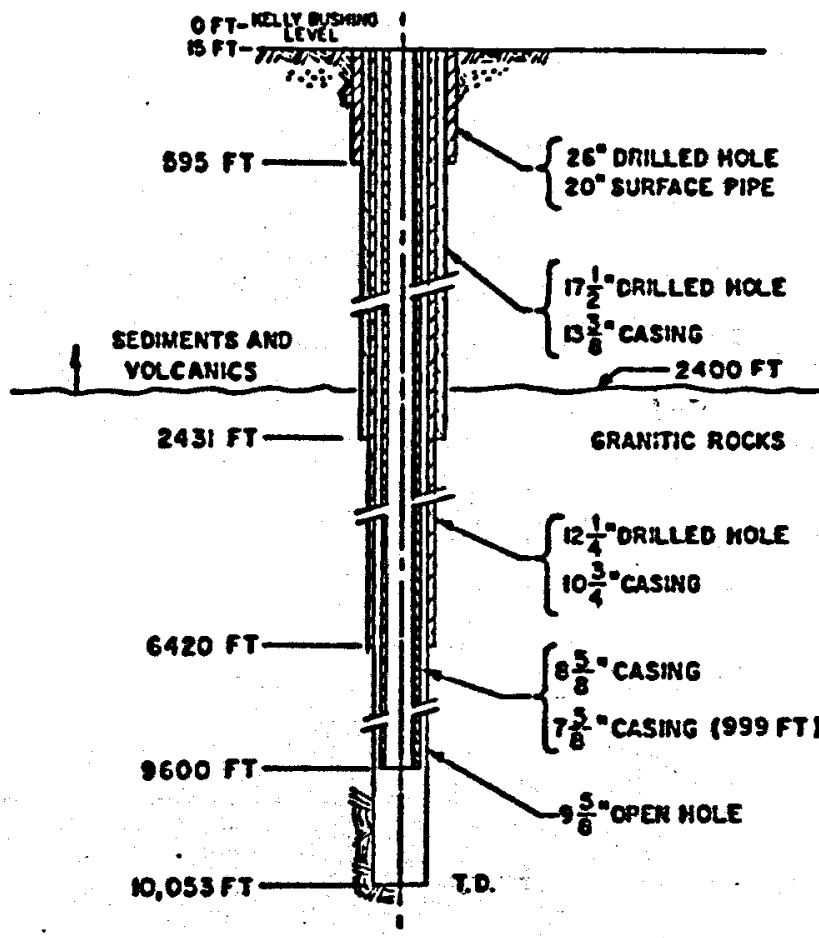

WELL EE-1

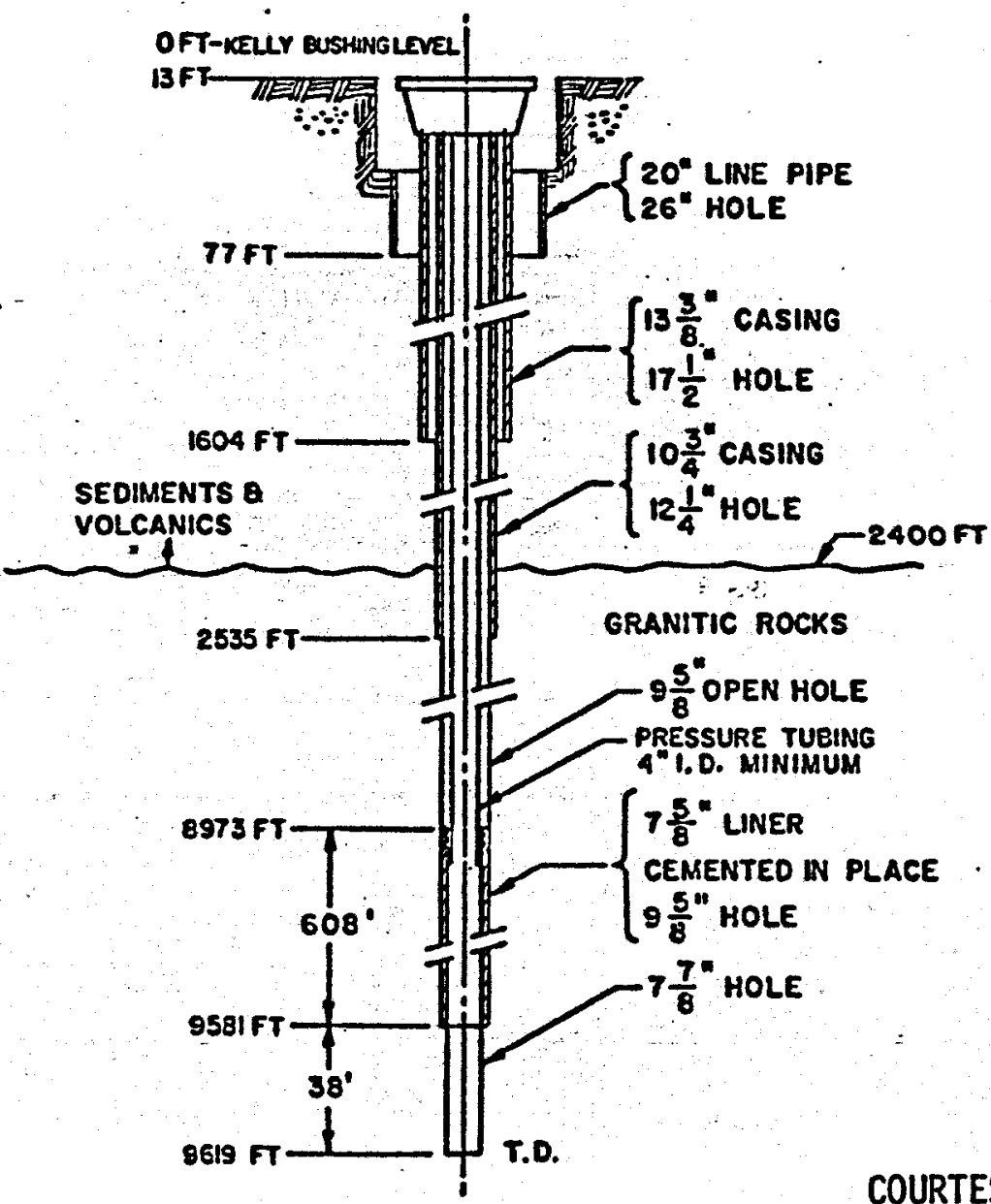

WELL GT-2 


\section{Project Conclusions, Recommendations}

The concilusions listed by Blair et al appear to be a reasonable sumary of work done through late 1976 in the Valles Caldera HDR evaluations. Major achievements claimed include:

- Successful conventional and directional drilling in hard crystalline rock to 10,000 foot depths and $390^{\circ} \mathrm{F}$ temperatures.

- Successful creation of hydraulic fractures in crystalline rock.

- Establishment of a downhole connection between two boreholes.

- Identification of and testing of acoustic instruments for mapping hydraulic fractures and distance ranging between wellbores.

- Measurement of reservoir properties by pressure-flow temperature logging, and

: Modeling of flufd flow and heat transfer in downhole systems.

Recognized major problems noted in order of priority include:

1. Need for accurate and reliable borehole surveying methods. Directional orthitng and guidance systems are marginal at $400^{\circ} \mathrm{F}$ temperatures. Gyroscopic, magnetic and plumb-bob devices need to be made more temperature resistant.

2. Hydrautfc fracture mapping techniques need to be perfected by adding to the downhole acoustic device with other well to well detection methods. (Note: This is even beyond the oil and gas Industry's state of the art and it would be a highly desirable tool for helping recover additional hydrocarbon reserves between widely spaced wells).

3. More reliable packer capabillity for hydraulicly fracturing $400^{\circ} \mathrm{F}$ plus basement rocks. (Note: It was suggested that tests indicate inflatable packers show highest promise for development to $570^{\circ} \mathrm{F}$, 
5,000 psi capability, but at present, this temperature exceeds the limits for known oil field, rubber type elastemers).

It was also suggested that development of an easily removable, cementedin liner would be one option to open hole fracturing. This could be a very practical application of the Pack Perf Completion System which is a 20 foot inflatable packer buflt on a section of casing. The rubber element is pumped full of cement and perforations are made through the pipe, cement and compressed element. (Figure 20). In this application, it would be an easily cemented and easily removable "scab" liner, $i$. e. the self centralizing feature and rubber covering could be easily washed over. Note: this system is manufactured by Lynes Inc., however the special design and application including the perforating techniques are patented features marketed by Completion Technology Company:

Other mechanical problems which are a function of high temperature and hard rock drilling'were evident in these tests, but not specifically noted. Obviously, they would be more severe at higher wellbore temperatures and must be considered to be limiting factors in plans to develop $400^{\circ} \mathrm{F}-$ $600^{\circ} \mathrm{F}$ prospects.

Scaling and corrosion problems may seem to be unrelated to HDR operations but the possibility of dissolving enough minerals from the extensive fracture surfaces to create a precipitate problem in the producing well is being investigated (Tester et al 1977).

The problem is expected to be silica dropout in the heat exchanger as the concentration becomes supersaturated with cooling. Silica dissolves quite rapidly at $400^{\circ} \mathrm{F}$ temperatures and the circulating waters could remove considerable volumes from the granite. Samples of circulated water with about 14 hours in situ exposure showed increasing $\mathrm{SiO}_{2}, \mathrm{Na}, \mathrm{K}, \mathrm{Cl}$ and $\mathrm{SO}_{4}$ to maximum 
levels of $260,300,40,400$ and $80 \mathrm{ppm}$, respectively.

The possibility of intentionally dissolving downhole rock to create new heating surfaces is also being investigated.

Corrosion is always a consideration with hot, wetted carbon steel surfaces. The problem here may be the difftculty in preventing oxygen contamination of the injected water. This could lead to serious producing well corrosion problems. 


\section{GULF COAST GEOPRESSURED GEOTHERMAL ZONE}

\section{Introduction, Program Status}

The geographic areas under consideration are located along the Louisiana and Texas Gulf of Mexico coast from the Mississippi Delta to the Mexican border. The geologic targets are thick Tertiary age sands deposited along the Northern edge of the Gulf of Mexico Basin. Special depositional features involving thick shale sections, growth faulting and a massive underiying salt bed combined to produce abnormally high reservoir pressures in the sands, and to charge them with water and dissolved methane gas.

The total resource potential of the geopressured geothermal zone has been widely discussed in other available publications. This report will deal with energy recovery on a per well basis. Certainly the problems to be discussed will indicate that any major resource development will be possible only with very large investments. And such investments may have to be justified as serving the National interest by preventing further dependence on imported crude oil.

A geopressured water well in the Frio or Miocene sand may be $12,000-$ 20,000 feet deep and have reservoir pressures of perhaps 11,000 psi to nearly $20,000 \mathrm{psi}$ ( $~ 1.0 \mathrm{psi} / \mathrm{foot}$ ). And reservoir temperatures may be in the range of $250-450^{\circ} \mathrm{F}\left(\simeq 2^{\circ} \mathrm{F} / 100\right.$ feet $)$. Flow rates of at least 40,000 barrels per day, bpd, will be required for commercial heat recovery. The brines will also contain $20-40$ cubic feet per barrel of dissolved methane gas which is readily marketable in existing systems. Completed well costs will be in the $\$ 3-5$ million range and per well energy recovery will likely be the equivalent of a 2-3 million cubic feet per day (MMcfd) natural gas well.

This general economic picture has prevented oil and gas industry par- 
ticipation, even with recent natural gas price hikes, despite the fact that some 4,000 wells have been drilled into geopressured zones seeking hydrocarbons. Legal problems may also limit or delay utilization of geopressured hot water resources occurring on leases with conventional hydrocarbon deposits.

Department of Energy (DOE) sponsored development is in the resource and reservoir evaluation stages. Considerable research has been completed on geology, exploration methods and legal considerations. And, as will be explained, one field test has been completed and two additional test programs are in progress:

1. Existing well test: One abandoned South Louisiana gas we11, the 13,000 foot Edna Delcambre 1 in Vermillion Parish, was donated to DOE for testing. Work was performed by OHRW Engineering and McNeese State University. A disposal well was drilled, two untapped water zones were perforated, and flow tests were made at various rates to examine mechanical, chemical and reservoir properties.

2. Proposed "wells of opportunity" tests. Gruy Federal of Houston has a contract to test six additional, existing geopressured wells. The project is in well selection stage and the cooperation of oil companies in furnishing wells is essential.

3. Grass roots well. DOE, University of Texas and General Crude 0 il Co. are participating in the Brazoria County, Texas, geopressured geothermal test in which a 16,500 foot Frio Sand well will be drilled on a General Crude lease, to be perforated and tested in various water bearing sands for mechanical behavior and reservoir performance. Completion plans are presently being finalized. 
In following discussions, Edna Delcambre 1 test results and the proposed Brazoria County well completion program and project goals will be presented. Basic concepts of the geopressured zone including relevant geologic background, reservoir rock characteristics and produced fluid properties will be explained. And four subsections will be devoted to interpretive discussions of: 1) Net energy recovery considering possible reinjection requirements, 2) Need for multiple casing strings and the effect on completion methods, 3) Sand control problems and need for new technology, and 4) Special consideration for completion program design in geopressured, hot water wells.

\section{Edna Delcambre 1 Well Test Summary}

Tentative data and transient behavior analyses will be published in proceedings of the Third Geopressured Geothermal Energy Conference held in Lafayette, Louisiana, November 16-18, 1977. The following is a summary of preliminary reports.

The ábandoned welr donated"to DOE for this test by an oil company was recompleted and equipped with a string of heavy wall $31 / 2$ inch $(9,700 \mathrm{ft})$ and $27 / 8$ inch $(3,000 \mathrm{ft})$ tubing, and necessary surface equipment to complete flow tests on two separate sands. The No. 3 sand, at 12,900 feet was perforated over 42 feet with 4 holes per foot and tested at various rates during a 23 day period. The No. 1 sand at 12,600 feet was perforated over 32 feet and also tested at increasing flows for 23 days. Water was pumped into a shallow disposal well drilled on the site. Separator gas was flared. The sands are located in the upper part of geopressured Miocene sands. Nearby fields produce hydrocarbons from the Miocene. The following table sumarizes important test data: 
Sand No. 1

Bottom hole pressure, psi

Bottom hole temperature, ${ }^{{ }} \mathbf{F}$ ?

Max. flow rate, bpd

Flowing tubing pressure at max rate, psi

Surface temperature at $\max$ rate, ${ }^{{ }^{F}}$

Average porosity $\%$

Average permeability, md

Final methane concentration, scf/bb]
10,900

234

12,653

1,798

220

38

360

$50 \div 60$
Sand No. 3

10,986

238

10,333

1,714

219

28

48

25-45

It was reported that water must be reduced to atmospheric pressure to separate the gas. Recombined samples indicated gas solubility of about $22 \mathrm{scf} / \mathrm{bbl}$ at 11,000 psi. The high concentration in Sand No: 1, which actually increased during the test, was not explained. Possibilities mentioned included communication to an upper gas sand, free gas within the zone or confact with higher gas'concentrations with drawdown. Sand No. 1 had a small free gas section and concentrations decreased during testing. Recovered gas was not pure methane. Measured heating value was 920,000 960,000 Btu/Mcf. Sand was produced from No. 3, and one-half of the perforations were covered after maximum flow tests, but No. 1 produced only a trace of sand. Buildup tests indicated skin effects, likely original drilling damage.

Reported mechanical problens included failure of rubber seals in line connections, and Neoprene impellers in meters. Packing glands on the welthead leaked. And rubber hoses rated to $250^{\circ} \mathrm{F}$ blistered. Corrosive conditions were noted by surface coupons and significant scale buildup was found in surface lines. Water analysis indicated total dissolved solids of 134,000 àña 715,000 ppm, respectively, in Sands No, 1 and No. 3. 


\section{Brazoria County Test: Goals, Completion Program}

To further assess resource : potential by actual production, a grass roots geopressured geothermal well will be drilled on a five-acre test site 40 miles south of Houston. Participants in the test are General Crude 0il Company (operator), Department of Energy and the University of Texas. This will be the first well drilled in the U.S. Gulf Coast for the purpose of producing geopressured hot water. Drilling is tentatively scheduled to conmence in early 1978.

The 16,500 foot Frio Sand Well is expected to be able to flow $40,000 \mathrm{bpd}$ of $300-360^{\circ} \mathrm{F}$ water with up to $40 \mathrm{scf} / \mathrm{bbl}$ methane gas. Bottom hole pressure will be about 14,000 psi and well head equipment must handle static surface pressures of 6,000-7,000 psi. The operation will demonstrate existing industry techniques for drilling and completing such wells. However, that is not the primary objective.

The DOE funded project is designed to provide information with which to evaluate the reservoir. Heat recovery tests will be incorporated into activities at a later date. During the first year, PIs will be measured at various flow rates to evaluate productivity and wellbore skin effects. Testing will be done in one interval at a time to simplify transient pressure behavior analyses. A surface reading BHP gauge attached to the tubing exterior will be used. As rates are increased, the well will be monitored for sand influx, downhole compaction, relative permeability effects and mechanical problems. Buildup tests, perhaps in the second year, will evaluate reservoir pressure loss after extensive fluid withdrawals.

Perforated intervals will be selected by $\log$ and core data to give a kh product of 5,000 or higher. This will likely require 125-220 feet of open sand. Flow will be initiated slowly for clean out, then raised in incremements 
of 1,000 bpd while monitoring sand. Stabilized flow for a 40 day period with $0.5 \%$ sand or less is desired. Hopefully, such tests can be run at 10,000 and 20,000 bpd levels. Later, two such zones could be produced simultaneously to give total rate of $40,000 \mathrm{bpd}$. As much as 900 feet of sand may be present in the well.

An estimated 1.6 Mifd of methane gas may be produced at maximum flows. Gas will be removed in two stages of separation. Low pressure gas will be compressed back up to 800 psi sales line pressure. Produced water will be cooled to the acceptable limit for pumps and then be injected into as many as four shallow disposal wells. Scaling and corrosion are expected to be significant problems and continuous monitoring programs will be needed to check for damage in high pressure surface facilities and lines. Barium sulfate will likely be the worst scaling product, as indicated by the following water analysis from offsetting wells:

\section{TYPICAL BRAZORIA COUNTY WATER ANALYSIS}

\begin{tabular}{lc}
\multicolumn{1}{c}{ Component } & Composition, mole\% \\
$\mathrm{BaSO}_{4}$ & 64.6 \\
$\mathrm{CaCO}_{3}$ & 13.3 \\
$\mathrm{Na}_{2} \mathrm{CO}_{3}$ & 7.0 \\
$\mathrm{Na}_{2} \mathrm{SO}_{4}$ & 6.3 \\
$\mathrm{FeS}$ & 2.8 \\
$\mathrm{SrSO}_{4}$ & 1.4 \\
$\mathrm{Siliceous} \mathrm{Material}$ & 3.2 \\
Moisture and Volatile & 0.4 \\
Loss at $900^{\circ} \mathrm{C}$ & $\frac{1.0}{100.0}$
\end{tabular}

*In addition, chloride concentrations of $80,000 \mathrm{ppm}$ are reported 
Proposed casing and wellhead programs are illustrated schematically in Figures 27 and 28 . These are preliminary designs that have been under public discussion for several months, and the final drilling and completion program likely will vary somewhat. The proposed logging, coring and sidewall sampling procedures also have been discussed in public meetings. However, detailed programs for primary cementing, casing and tubing installation, and perforating have not yet been presented. Hopefully, documentation of the completion procedure, interval flow performance and formation rock evaluations will be complete enough to allow identification of conditions conducive to sand flow and/or other productivity impairment.

\section{Geopressures: Definition, Discussion}

The Gulf Coast geopressured zones developed from the succession of events that in 30-40 million years filled one edge of the Gulf of Mexico Basin with as much as 40-50 thousand feet of quartz sand, clays and silts washed down from the eroding Rocky Mountains by Mississippi-size prehistoric rivers. The first sands were deposited in the early basin edge which is now farther inland from the coast, Figure 29. In succeeding eras, new deposits were forced to flow over preceding layers, forming thicker beds as they filled the gradually deepening basin. The older, deeply buried sands, are thus more compacted and partially cemented with chemicals deposited from prehistoric waters. The newer sands, deposited more recently on the Gulfward side of the deltas, have much higher porosities and permeabilities.

The building of deposits in the ever deepening basin caused a series of growth faults and secondary faulting that vertically separated sand and shale sections, effectively sealing off many sand lenses. Certain shale sections, by a combination of chemical, pressure and temperature effects 
$20^{\circ} \csc$

$24^{\prime \prime}$ HOLE

1805 sx

GROUND LEVEL

13-3A" CSG

$17-1 / 2^{\prime \prime}$ HOLE

$4800 \mathrm{sX}$

$9-5 / \theta^{\prime \prime} \csc$.

$12-114^{\prime \prime}$ HOLE.

$2500 \cdot 5 x$

$7-5 / \theta^{\prime \prime} \cdot \csc$. TOP $14,800^{\circ}$

$0.1 / 2^{*}$ HOLE

$325 s x$

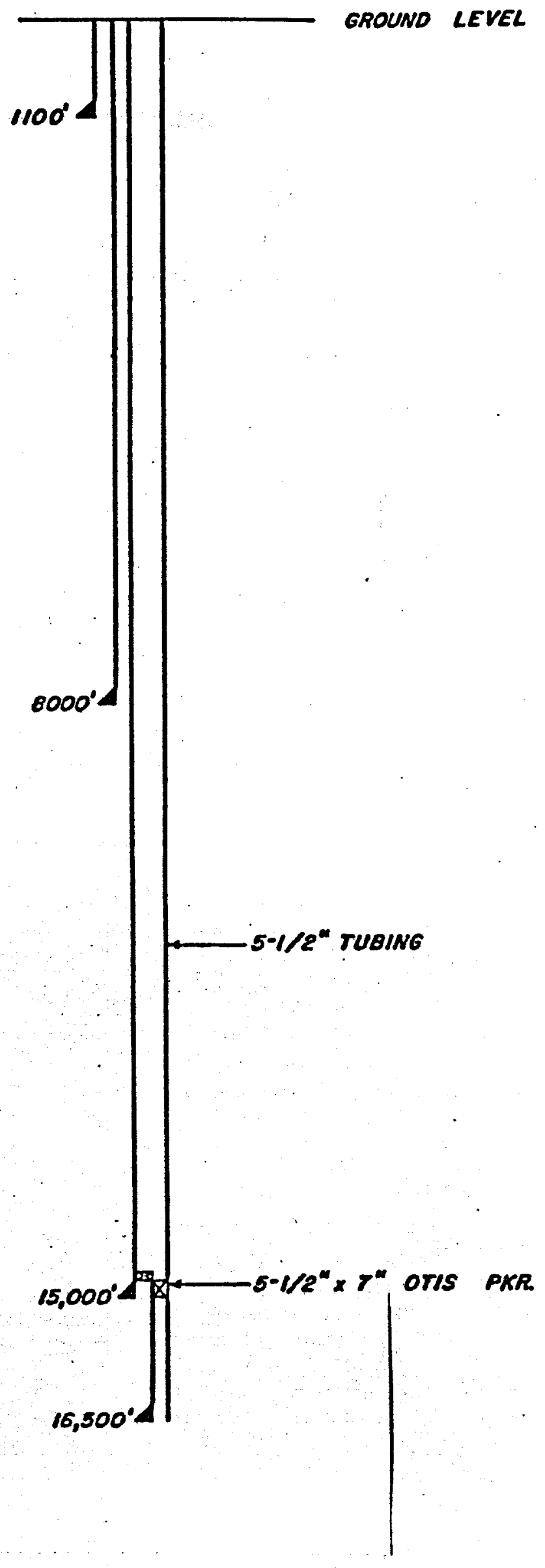

PRELIMINARY CASING PROGRAM FOR THE BRAZORIA COUNTY, TEXAS, GEOPRESSURED GEOTHERMAL TEST WELL. 


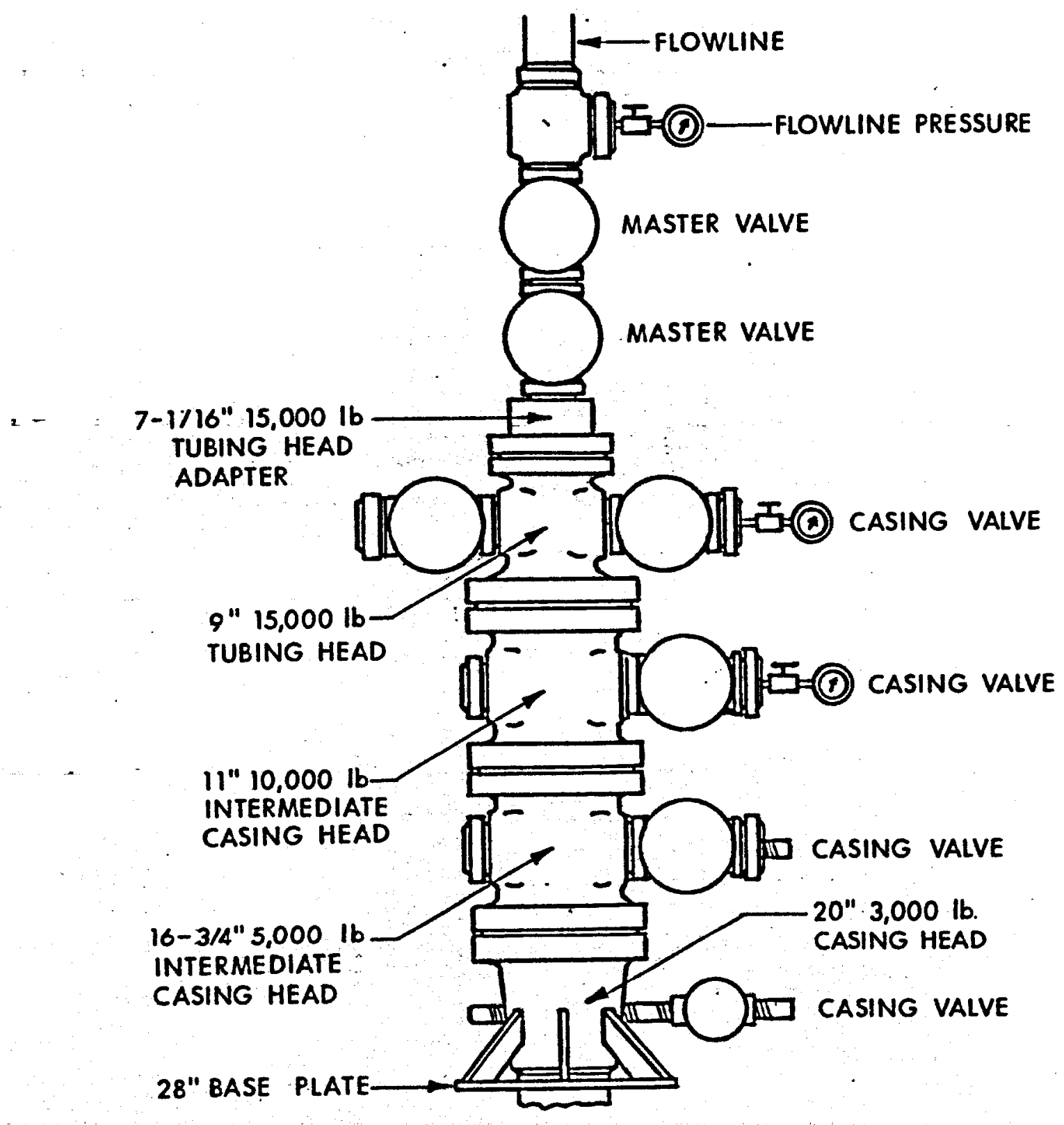

SCHEMATIC OF HIGH PRESSURE WELLHEADS USED FOR MULTIPLE CASING STRING COMPLETIONS IN THE U.S. GULF COAST.

FIGURE 28 


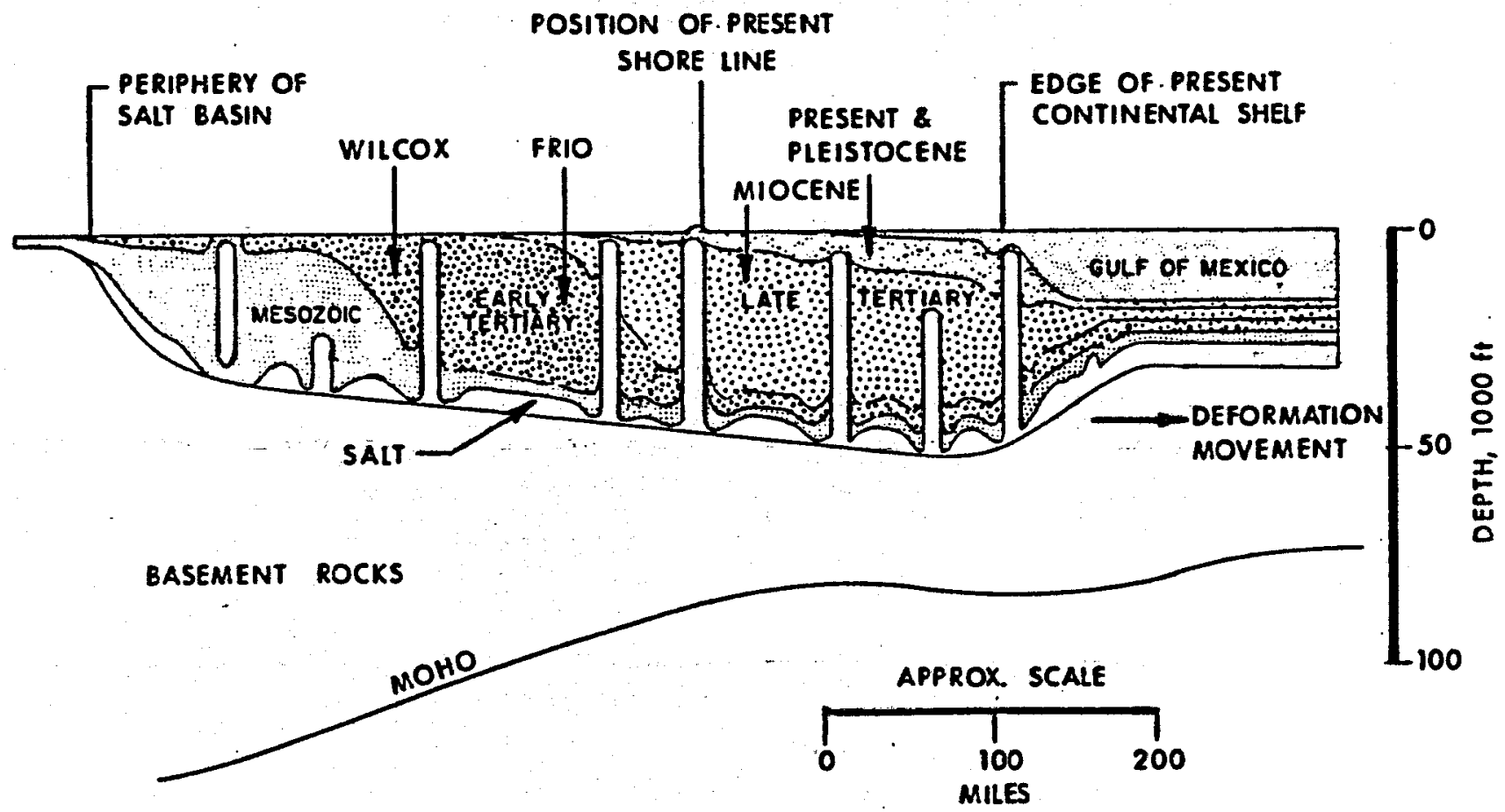

ADAPTED FROM JONES

IDEALIZED NORTH-SOUTH CROSS SECTION OF PRINCIPAL DEPOSITIONAL FEATURES THROUGH THE U.S. GULF COAST GEOPRESSURED GEOTHERMAL ZONE.

FIGURE 29 
became impermeable and prevented vertical movement of fluids. Thus waters below these caprocks became entrapped within the pore spaces of the sediments. And as the basin floor was deepened by continual deposition, these entrapped waters were forced to support the weight of everything above them, ie. the overburden:

In the Gulf Coast, overburden density increases rapidly with depth near the surface, but at the top of deeper geopressured zones, the average pressure gradient approaches $1.0 \mathrm{psi} / \mathrm{ft}$ of total depth. Except in unusual cases, this is the upper limit of geopressures. Actual maximum pressures are somewhat less, perhaps $0.9-0.95 \mathrm{psi} / \mathrm{ft}$. Above the caprock where fluids are free to move, rocks continue to compact with depth, increasing density as mentioned above. In the process, fluids are displaced but pore pressure is still equal to the weight of a column of water, ie. hydrostatic. Everything above the caprock is in the "hydropressure" zone and pressures at any point are equal to a salt water gradient $(0.465 \mathrm{psi} / \mathrm{ft})$ times depth. Effects of pressure gradient change on drilling well control and casing design will be discussed later.

Thick shale sections below caprocks influence content of the sand lenses. The shales are the source of methane gas, and waters filtered through these fine grain rocks into the sands normally are fresher than the ancient sea waters.

Geopressured zones are typically hotter than adjacent hydropressured sediments because lack of fluid movement has prevented dispersion of rising heat from the earth's mantle. And the gradient departs radically from the $1^{\circ} \mathrm{F} /$ 100 feet common in hydropressures. As a rule of thumb, bottom hole temperatures in deeper geopressured zones may be about $2^{0}$ F/100 feet of total depth.

The basic concepts discussed above create conditions that are detectable before and during drilling so that the top of the geopressured section can be 
determined. The primary rock change is the increase in shale porosity caused by the internal support of geopressured water that prevented further compaction. This condition decreases rock density, makes the rock easier to drill, changes the seismic velocity, and increases water percentage to greatly affect electrical properties. Idealized curves showing the basic effects are presented in Figures 30 and 31. If such data can be obtained while drilling, by continually measuring properties of shale cuttings, the transition zone may be detected. Returning mud temperature is a relative indicator, but does not read true BHTs:

Salt domes (Figure:29) can greatly alter geopressured zone properties. These massive domes pierced upward through the sediments due to density differences (early salt temperature were likely over $600^{\circ} \mathrm{F}$ ) and deformation of the underlying salt bed. Salt is 3-4 times as effective as reservoir rock in conducting heat. Thus, nearby salt domes may alter local geopressure temperatures. Salt domes also alter water chemistry. Geopressured waters can be made more saline than upper hydropressured zone:waters in contrast to the normal trend.

\section{Guif Coast Reservoir Characteristics}

In Texas, the primary geopressured zone target is the Frio sand of middle Tertiary Age (Figure 29). It is found along the onshore coastal plain, below geopressure transition zone depths of perhaps 10,000 to 13,000 feet. The older Vicksburg and Wilcox of early Tertiary age lie below the Frio near the coast and become more shallow farther inland where they are important hydrocarbon producers. In certain geographical areas these two sands could be geopressured hot water targets. In Louisiana, younger Miocene age geopressured hot water sands are found below somewhat shallower geopressure tops, perhaps up to 8,000 feet, along the coast and offshore. 


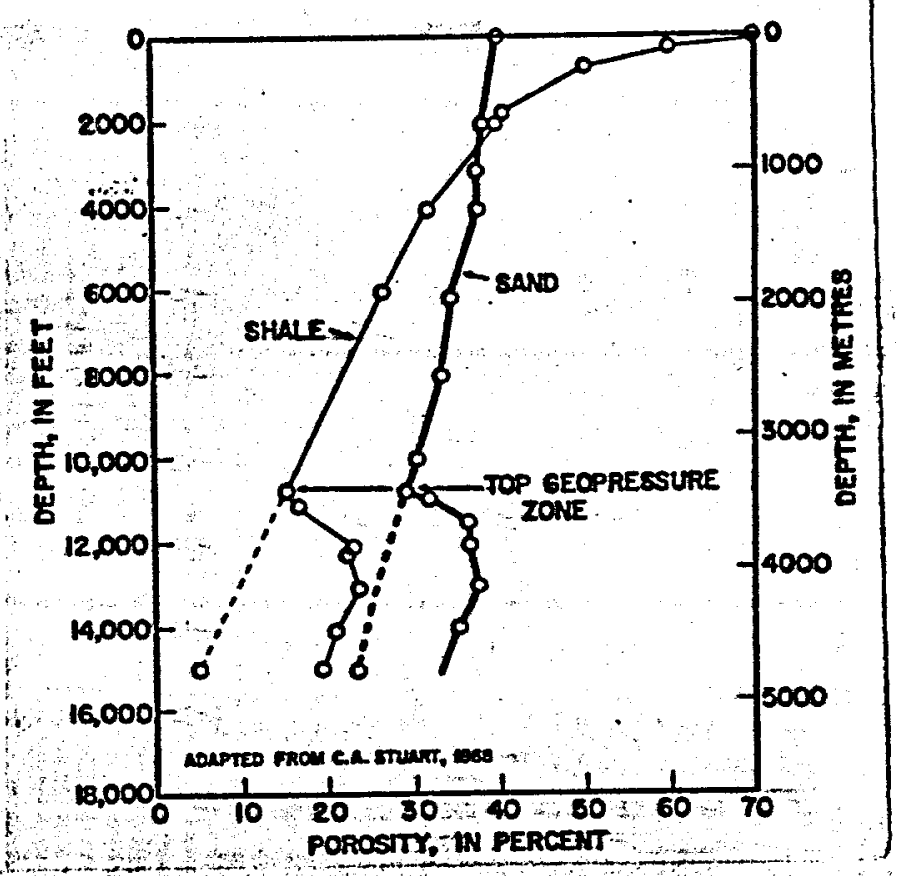

EXPECTED POROSITY BEHAVIOR CAUSED BY SUPPORT OF PRESSURED FLUID IN GEOPRESSURED ZONES.: FROM JONES (1975).

FIGURE 30
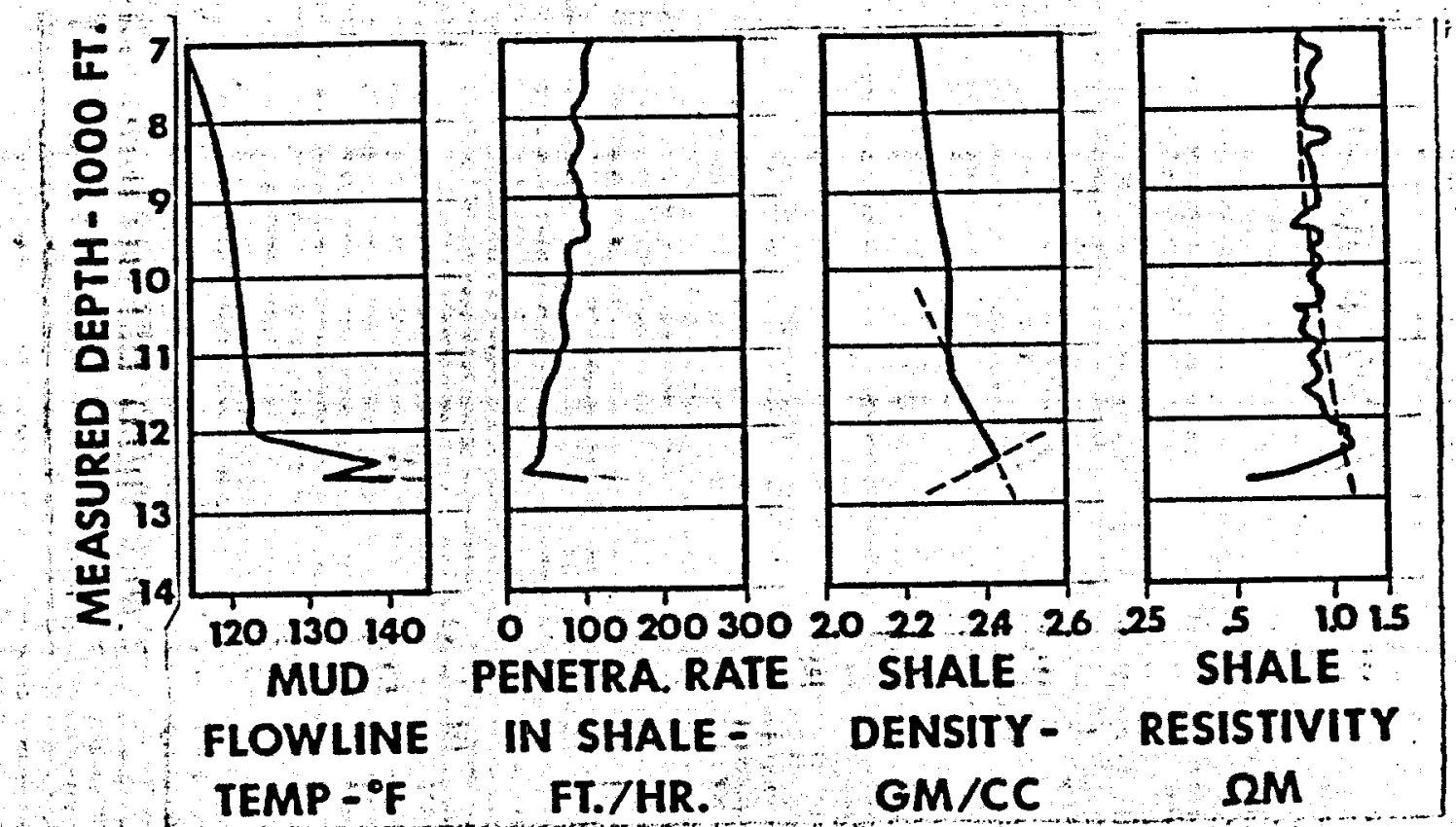

COMMON METHODS FOR DETECTING GEOPRESSURE TRANSITION ZONES WHILE DRILLING. MODIFIED FROM JONES (1975). 
Suitable geothermal fairways (areas containing potentially attractive sites) are judged by the presence of at least $20 \%$ sand with 20 md permeability in geopressured zones below the $300^{\circ} \mathrm{F}$ isotherm. This was generally the criteria for defining the 20 mile long by 10 mile wide Brazoria County fairway in which the final test site was determined by environmental and other factors:.

Sand characteristics are greatly altered by age and depth of burial. Shallower sand porosity is primarily a function of compaction and cementation at grain contact points. Deeper sands have high clay content, and mineralization may have nearly filled pore spaces at one time. Thin section analyses show that secondary leaching of this mineralization may be the primary porosity. Frio sand porosities vary from $15-25 \%$ with $20 \%$ being typical. Acceptable permeabilities are in the order of 20-50 md. Deeply buried Wilcox sands would likely have less desireable properties. However, geopressured Miocene sands can have permeabilities of several hundred ind.

These variations in permeabilities directly affect completion methods. Frjo sands are capable of PIs of probably $50 \mathrm{bpd} / \mathrm{psi}$, or less. This would require a kh product of $10,000 \mathrm{md} \mathrm{ft}$. And for an average $20 \mathrm{md}$ permeability, 500 feet of net sand would be required. This long section would be difficult to treat for productivity damage by stimulation, for example, and reliable sand control by gravel packing would be very difficult/and or expensive.

The lower permeabilities are sensitive to impairment by particle plugging. This could be a critical factor in geopressured zone project success if it is proved that reinjection of cooled water back into the producing formation is necessary for acceptable reservoir life. Lab tests have indicated that water of higher quality than that of average drinking water irreversibly damages fine grained Gulf coast sands. Considering the high TDS content of water and the difficulty of treating a plant effluent to the high standards required, the frio would not likely tolerate high volume reinjection. Miocene sands with 
permeabilities 10 times greater, might not be so sensitive to damage. Hydraulic requirements of reinjection to the same formation will be discussed later.

\section{Produced Fluids: Water Properties, Methane}

The normal trend in entering geopressured zones is toward fresher waters, as the thick shales filtered out salts in early flows, before changes in the clays prevented further loss to pressurized sands (Jones). But, this is not a general rule, and the advantage of $10 w$ salt concentrations cannot be considered in all combletions.... As mentioned, nearby salt domes can also radically change water properties.

Kharaka (1977) reported on Brazoria County, Texas, water tests in which salinity in the geopressured zone is higher than in the hydropressures, the opposite of the previously reported trend. Actual TDS in the two zones were 60,000 and $40,000 \mathrm{ppm}$, respectively. In summarizing overall results of 54 water tests on the Texas Gulf Coast, Kharaka says analyses show that salinity generally decreases in the geopressured zone, but not always. And salinities are generally higher than the 5,000 ppm values reported in literature.

It is also noted that $\mathrm{H}_{2} \mathrm{~S}$ and silica, important problems in most geothermal fields, are low in Gulf Coast geopressured waters. While reported $\mathrm{H}_{2} \mathrm{~S}$ concentrations are apparently low, completion engineers should not automatically accept them as being below concentrations that can cause hydrogen embrittlement in high strength (high carbon) steels. And in combination with trace oxygen contamination, downstream corrosion in disposal or injection wells could be seyere.

Methane gas in solution in geopressured waters is the outstanding difference between Gulf Coast geopressured hot waters and "conventional" geothermal water. Early geopressured geothermal investigations proposed 
projects on expected methane concentrations of some $20 \mathrm{scf} / \mathrm{bbl}$. and project economics relied heavily on heat recovery. The Edna Delcambre 1 well test produced methane at over twice this concentration and these results greatly increased optimism for economic viability. Proceedings of the Third Geopressured Geothermal Conference in Lafayette in November 1977 included several papers that attempted to explain hydrocarbon solubilities in reservoir waters that exceeded those attainable in laboratories by recombining gas and water under pressure.

The accepted standard for methane solubility has been Culberson and McKetta data (1951). These data have been recently extended to higher temperatures by incorporating 1972 work of three Soviet researchers, see Figure 32. The resulting curves are for fresh water. For Gulf Coast brines, it has been reported that curve values should be decreased by $10 \%$.

In support of the solubility data shown in Figure 32, tests on water from a major oil company's well in a 20,600 foot geopressured zone near Baton Rouge, Louisiana, that was flowing 100 barrels per hour indicated 107 scf/bbl. Water salinity was only 12,000 ppm. . The wells BHP was 16,000 psi and temperature was $425^{\circ} \mathrm{F}$.

Resource Description, Net Energy

Unl ike other forms of geothermal development, which can produce only heat, the Gulf Coast geopressured geothermal zone contains three forms of energy: Heat, hydrocarbon and kinetic energy. However, it appears that the methane gas is the primary energy product. Heat recovery will be a secondary contribution. And there may be no net recovery of hydraulic (kinetic) energy, depending on water disposal requirements. The following discussion explains this evaluation: 


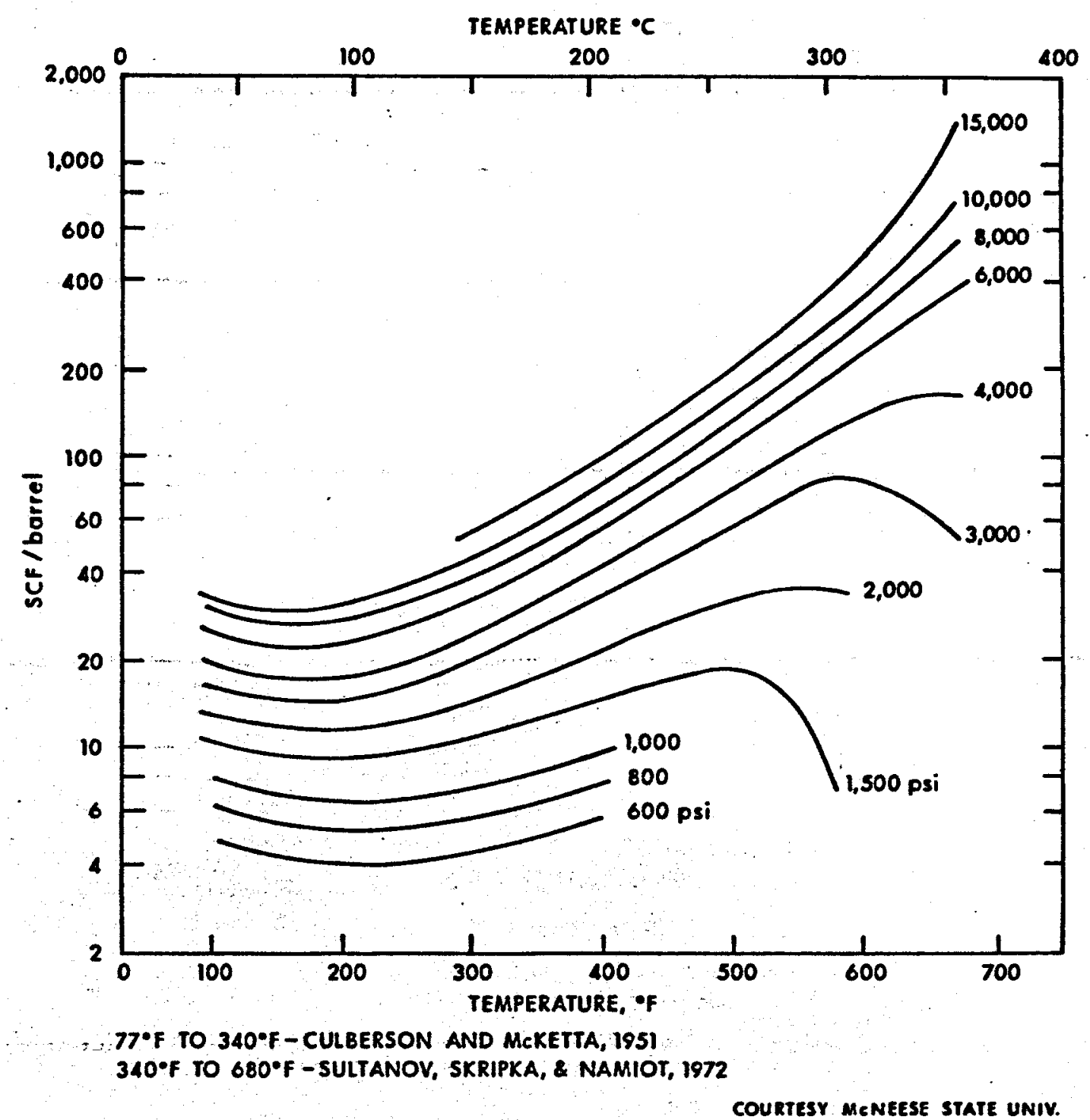

METHANE SOLUBILITY IN FRESH WATER. SUGGESTED CORRECTION FOR MODERATE BRINES IS A $10 \%$ DECREASE.

FIGURE 32 
Methane gas recovery can be estimated for a hypothetical well using the solubility data in Figure 32. Assuming a 17,500 foot well with 15,000 psi BHP and $360^{\circ} \mathrm{F}$ BHT and typical salinity, the curves indicate $80 \mathrm{scf} / \mathrm{bbl}$ for fresh water. Derating this by the 10\% factor for brine gives $72 \mathrm{scf} / \mathrm{bbl}$. And derating this another $6 \%$ for contamination leaves an estimated $68 \mathrm{scf} / \mathrm{bbl}$ pure methane. Thus, for $40,000 \mathrm{bpd}$, maximum methane recovery could be 2.7 million cubic feet per day, MMcfd. The same criteria for a 14,000 foot well with 12,000 psi BHP and $294^{\circ} \mathrm{F}$ BHT gives a maximum recovery of 1.7 MMcfd.

While solubilities in figure 32 are more optimistic than early planners considered, gas production is minimal for high costs involved. Considering continual compression and dehydration costs to put this gas into interstate pipe iones at present new gas prices in the range of $\$ 1.65 /$ Mcf, marginal economics are foreseen for developments in which per well drilling and completion costs are in the \$3-5 million dollar range.

The contribution of the heat in the water (enthalpy) will vary greatly with the efficiency of the system. In an example case, 40,000 bpd of $360^{\circ} \mathrm{F}$ water cooled to $100^{\circ} \mathrm{F}$ would give up nearly 3.5 billion Btu per day (using the close approximation of $1 \mathrm{BTU} / \mathrm{b} /{ }^{\circ} \mathrm{F}$ ). This is a gross energy release equivalent to 3.5 Mcfd pure methane production $(1,000 \mathrm{Btu} / \mathrm{scf})$. If $20 \%$ of this heat energy is converted into electricity, the well's heat output would be equivalent to 700 Mcfd natural gas. Thus the combined methane and heat output, before reinjection energy requirements are subtracted, might be equivalent to a 3.5 MMcfd Gulf Coast natural gas well.

No net hydraulic energy recovery can be anticipated if water must be pumped into anything but extremely shallow, very high permeability disposal wells equipped with large diameter tubing. If reservoir evaluations prove that water must be reinjected into geopressured zones, the 1 imitation will be so 
severe that Gulf Coast geopressured geothermal development may not be feasible. Figure 33 from R.M. Jorda's January 1978 Water Reinjection Study (Sandia Contract 05-6199) shows expected injection well performance for a 5,000 foot Gulf Coast well with 150 md sand and 250 net feet open. It is seen that even with 7 inch tubing with no corrosion considered, 40,000 bwpd injection of $90^{\circ} \mathrm{F}$ water will require 1,100 psi surface pressure. Surface flowing pressures cannot be significantly higher than this on production wells unless very large tubing strings are used. And the hydraulic energy cannot be directly applied to disposal as produced water must be dropped to atmospheric pressure to release the methane.

In the worst case, water would have to be returned to the producing reservoir. And model studies presented at the Third Gulf Coast Geopressured Geothermal Symposium indicated that this would actually be required for maximum methane recoveries and longest reservoir life. In the present state of the art, this may not be possible.

Assuming a Frio Sand BHP of 14,000 psi at 16,500 feet, and hydrostatic pressure of a cooled column of brine at 7,900 psi, surface pressure merely to balance the differential at the bottom of the hole would be a minimum 6,100 psi. With mildly corroded $51 / 2$ inch tubing, friction loss at 40,000 bpd would add another 5,000 psi ( $307 \mathrm{psi} / 1,000 \mathrm{ft}$ ) and even 7 inch tubing would have 1,370 psi friction loss. And additional $\Delta P$, perhaps up to 4,000 psi could be required to drive the water into the formation. Thus, even with 7 inch tubing, surface injection pressures would be over 11,000 psi. Sustained pumping of high volumes of brine at such pressure levels is not possible with existing pumping equipment. 


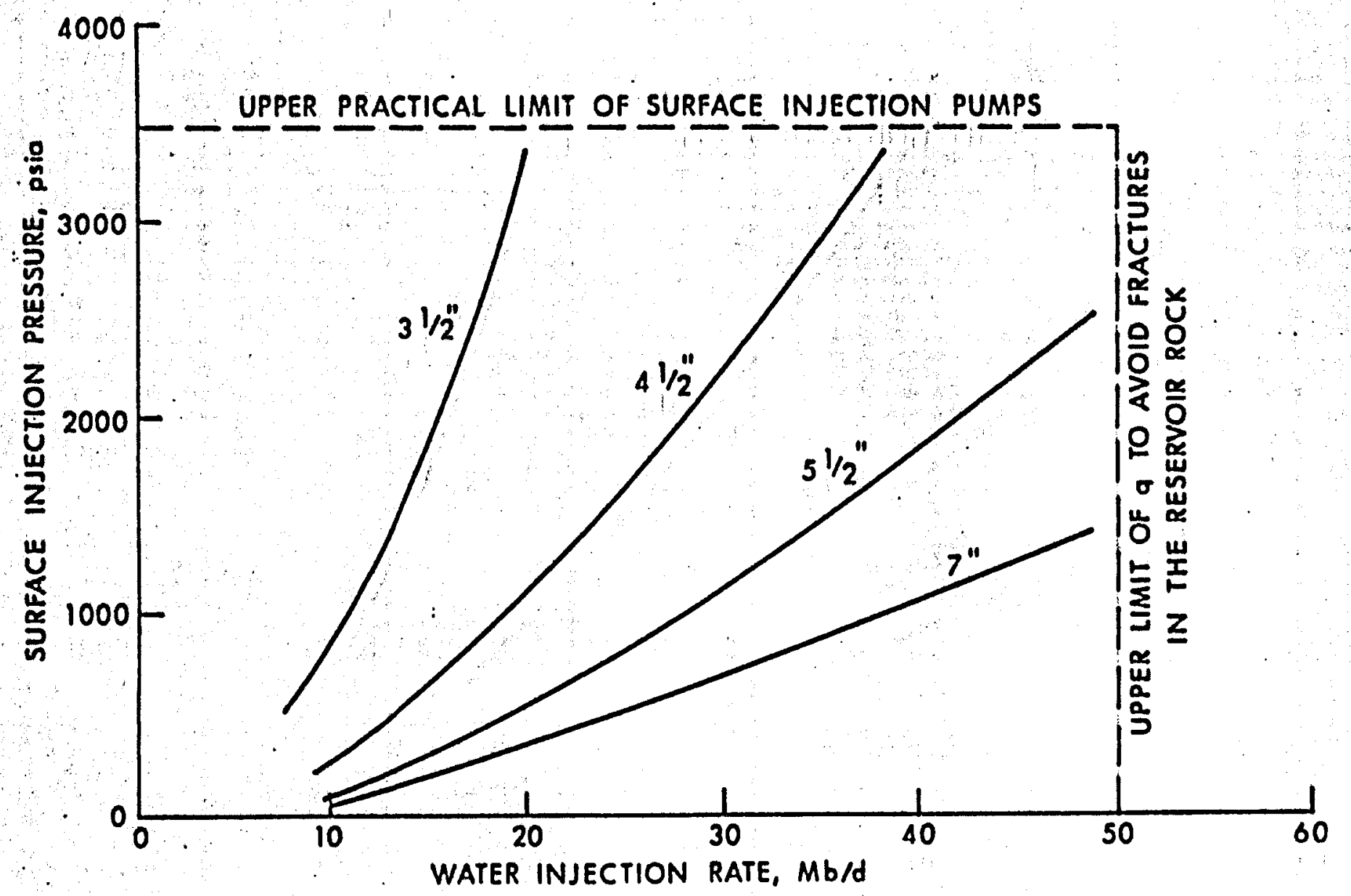

THE IWPA FOR THE EXAMPLE INJECTION WELL. THIS ANALYSIS SUGGESTS THAT A MINIMUM SIZE OF $5 \frac{1}{2}$ " (NOMINAL) SHOULO BE USED. 


\section{Pressure Control, Casing-Liner Programs}

Control of a geopressured well during drilling is complicated by the fact that reservoir pressure gradients change between various depth levels downhole, while the driller can only vary one pressure control mechanism, ie. the average weight of the mud column. In hydropressured zones, mud weight can be raised to slightly more than the weight of salt water $(8.9 \mathrm{ppg})$ and any formation flow will be prevented by the mud overbalance.

In geopressured sediments, particulariy through the transition zone, formation pressures increase rapidly (see Fjgure 34 ) and it becomes difficult to control the pressure balance between mud weight and formation pressure in the top and bottom of the open hole section with one mud weight. In Figure 34 for example, it is seen that $15 \mathrm{ppg}$ mud would exert 8,200 psi BHP at point A, enough to safely overbalance actual formation pressure. However at point $B$ in the open hole, perhaps only 300-400 feet above $A$, formation pressure is only 4,500 psi, but mud pressure is nearly 7,800 psi. The 3,300 psi overbalance at point $B$ is approaching the break down pressure of certain formations.

To prevent such problems, zones with steep pressure gradients must be cased with intermediate casing or liner, so that deeper drilling can be continued with higher mud weights.

In a Gulf Coast geothermal prospect, hole size, TD and the expected number of casing strings must be planned carefully because the critical requirement is to be able to complete the well with tubing that is large enough to provide adequate total flow. By miscalculating and being forced to set an extra liner, the final hole size may be too small. A discussion of tubing size vs. PI will be presented later, to indicate what minimum tubing diameters may be required. 


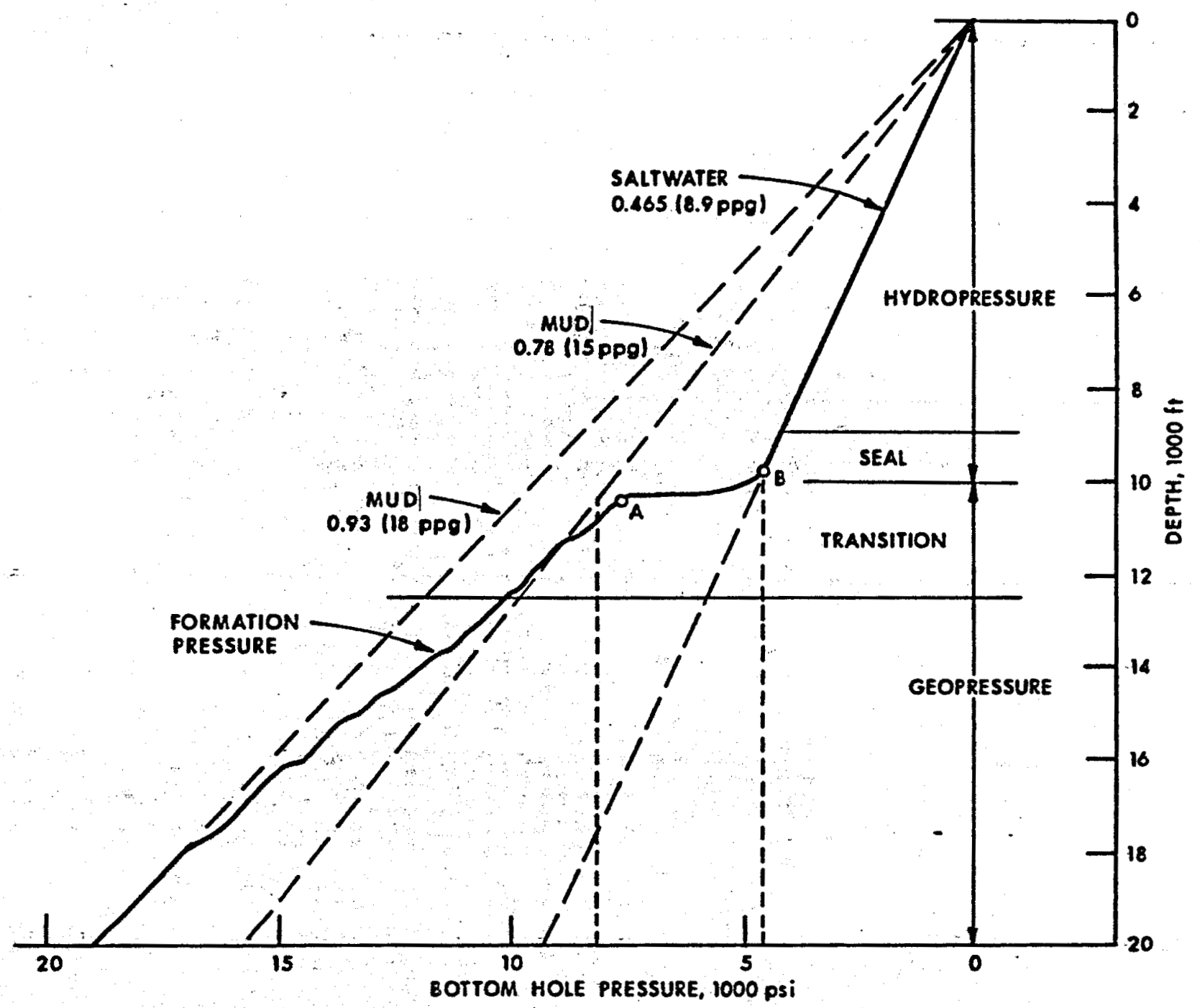

ADAPTED FROM STUART

FORMATION PRESSURE GRADIENT BEHAVIOR THROUGH HYDROPRESSURED AND GEOPRESSURED ZONES. NOTE THAT 15 PPG MUD REQUIRED TO CONTROL POINT A WOULD BE EXCESSIVE AT POINT B ONLY A FEW HUNDRED FEET UP THE HOLE.

FIGURE 34 
Sand Production, Control: Problems

Tertiary age sands of the U.S. Gulf Coast are much finer grained than California sands. Sieve analyses typically show a 50 percentile (median) grain diameter of 0.004 inch, with maximum diameters less than 0.01 inch. These sands may be dislodged from the formation and carried into the wellbore by fluid flow in a concentration that is dependent on flow velocity, type of fluid, and formation rock strength under existing stress states.

The type of fluid and the original rock strength are difficult to control in a pnoducing well. But flow velocity and the point at which velocity is highest can be controlled by varying production rate and by reducing skin effects or plugged perforations that limit total available flow paths.

The formation stress state can be radically changed in the critical area around the wellbore by improper drilling and completion methods that fail to provide for hole stability. Once sand flow starts, redistribution of the intergranular stresses further destabilizes the rock. Movement of the formation can accelerate clay particlemigration; and it can destroy any stable sand bridges that have formed across perforation tunnels. And, with enough sand flow, the lateral loading on casing strings can be redistributed so as to apply high buckling forces.

The basic sanding mechanisms have not been investigated for geopressured hot water wells. Limited tests have proved that influx is rate sensitive, ie. there is a critical velocity or drawdown through perforations at which sand starts to flow. These conditions need to be defined so that minimum total intervals, perforation shot densities and diameters can be established. Studies need to be made on core samples in hot water flows to evaluate surface tension, clay behavior, compressive strength retention effects, etc., and how they differ from those in 011 and gas flow. And the effects of 
methane gas break out around the wellbore as a skin effect should be / considered. Accurate sand monitoring systems should be installed on all wells to detect the start of sand flows. Various monitors and detectors are available, one type records the noise of sand particles striking a probe in the flowline. Another type has a thin walled probe that transmits pressure signals when the wall is eroded.

Sand control will not be easy in high pressure hot water wells. It is probably not even feasible to completely control sand. That highly desireable goal has not been achieved in $0 i 1$ and gas wells, under less severe conditions. There are three basic options available for sand control: 1) Influx can be screened 2) The formation can be chemically consolidated, or 3) The formation stress state can be controlled to promote natural bridging. The last option appears most practical.

Screening methods that have been most successful on the Gulf Coast include gravel packing around the metal screen. An open hole job in which an enlarged (underreamed) hole is packed so as to provide both screening and formation support would provide maximum productivity. But reaming and maintaining borehole stability over long intervals with $18 \mathrm{ppg}$ high solids completion fluids would be difficult and costly. And such fluids would not be satisfactory for packing gravel behind screens. Open hole packs are rarely done in/ Gulf Coast Wells.

Inside gravel packs are successful only if gravel can be packed into large diameter, clean perforation tunnels so as to stop sand fiow before it enters the tunnels. To place gravel in the perforations, the carrying fluid must enter the formation. Economical, "clean" $18 \mathrm{ppg}$ completion fluids are not available. for example, one new product, a lithium bromide solution would cost $\$ 300-400$ per barrel. Such jobs may be feasible in thin oil or gas sands, but completing several hundred feet would involve several stages and prohibitive costs. 
Consolidation by injection of epoxy type chemicals is possible in thinner, high permeability sections where some permeability reduction can be tolerated and chemical cost requirements are not excessive. Geopressured sands would have to be studied very carefully before using any chemical injection that would reduce already marginal permeability. And treatment temperature limits are presently below most target reservoir temperatures. Conventional consolidation jobs have been plagued by basic fluid placement problems.

Stress control can be applied as part of the completion procedure. An efficient primary cement job followed by properly designed perforating is the most practical starting point for sand control. But deep, hot hole conditions will limit the effectiveness of primary cementing and result in mud contamination and channeling. The Pack Perf Completion Systentiscussed and illustrated earlier in this report offers one method for assuring both proper cement placement and stress support across the sand face. This system features an external casing packer that is pumped full of cement, then perforated. Comparative tests of individual zones with and without the packer could give valuable data on sand control capability.

\section{Completion Design Considerations}

This subsection will present several considerations that should be included in engineering preplanning of Gulf Coast geopressured geothermal wells, namely:

1. Tubing size selection and stimulation to achieve desired flow

2. Casing, liner joint design for high tensile loads and thermal stresses

3. High strength metallurgy limitations for possible hydrogen embrittlement

4. Perforating performance requirements

5. High density completion fluid limitations

* A development of Completion Technology Company 
6. Primary cementing needs and problems

7. Special effects of hot water on elastomers, and

8. Well control equipment, surface vs. subsurface safety valves.

Tubing size, PI. Factors that influence tubing selection were used to generate data for Figure 35 . The upper PI curve $(46.3 \mathrm{bpd} / \mathrm{psi})$ is a calculated value for a typical 16,500 foot Frio sand with a kh of 10,000 md $\mathrm{ft}, 80$ acre spacing, an 8 inch wellbore and a water viscosity of $0.2 \mathrm{cp}$. Friction drops are calculated for medium weight, non-corroded pipe. Surface pressure was assumed to be 500 psi. No beneficial 1 ift from methane breakout was considered.

It is seen that under calculated PI conditions, the maximum that will flow through $51 / 2$ inch tubing is 50,000 bpd. Either reduction of tubing ID by scaling, or a steepening of the friction curve by corrosion effects would lower the string's flow capacity.

If the well's PI is actually lower, higher bottom hole $\triangle P S$ are required to give the same flow and less is available to offset friction loss. For a PI of $10 \mathrm{bpd} / \mathrm{psi}$, for example, $40,000 \mathrm{bpd}$ flow would require 7 inch tubing.

To improve low. PIs that may be the result of skin effects, ie. shallow formation plugging by drilling damage, etc., some type of formation treatment (stimulation) will be required. Hydraulic fracturing effectiveness will be limited by the availability of economical non-damaging carrying fluids with reasonable friction loss properties. The long intervals will require staged treatments to assure adequate flow. Embedment of propping materials can limit job life. Gulf Coast sands are not normally fracture treated.

Acid washes will have to be tailored to the special sand properties of water wells. And inhibition of acids containing chlorides, to prevent tubular damage, will be difficult and very expensive above $275^{\circ} \mathrm{F}$ temperatures. To allow service companies and other researchers to develop acceptable stimulation 


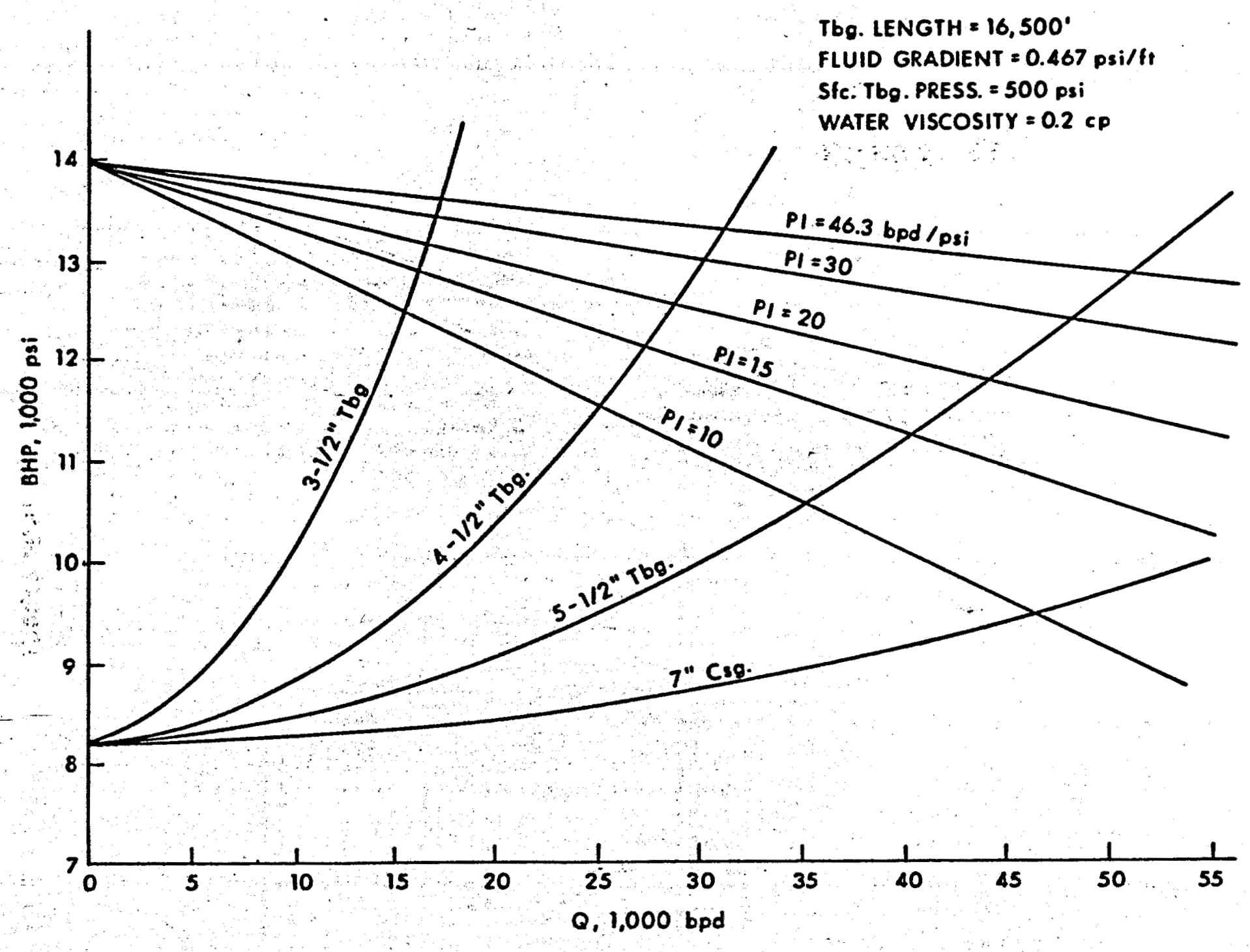

DATA BY R.M. JORDA

FLOW CAPACITIES FOR VARIOUS TUBING SIZES CONSIDERING FORMATION PI AND FRICTION LOSS IN NEW PIPE. NO METHANE BREAKOUT IN TUBING WAS ASSUMED. IN ACTUAL DESIGNS, THE BENEFIT OF TWO PHASE FLOW SHOULD BE CONSIDERED.

FIGURE 35 
techniques, cores and other relevant formation data, must be set aside and made available. And in any forthcoming well tests, service companies should be selected well in advance and given all known and estimated parameters so that state of the art methods can be applied and documented in a learning manner.

Joint design. Very long casing or liner strings will be extremely heavy and will require rigs that can handle one million pound hook loads. For example, a 15,000 foot string of mixed weight $95 / 8$ inch casing will weigh nearly 850,000 pounds in air. Of course, buoyancy effects of mud will lessen this weight in the hole, but during cementing there will be drag forces and possible differential sticking conditions that will increase lifting requirements.

The upper part of very heavy strings should be equipped with API Buttress threads, at the very least, to handle high tensile loads. Also available are premium, non-API joints that feature metal to metal seals, and shouldering surfaces that can tolerate high compressive loads. Such loading could occur in very hot $\left(>400^{\circ} \mathrm{F}\right)$ wells subject to cyclic thermal conditions. It should be remembered that tubular design for oil and gas wells cannot be casually applied to hot water wells with the same bottom hole temperatures. Inflowing gas and oil are exposed to a natural cooling effect caused by pressure loss; and the heat conductivities of gas and crude oil are significantly less than for water.

Hydrogen embrittlement. Hydrogen sulfide gas $\left(\mathrm{H}_{2} \mathrm{~S}\right)$ concentration in high pressure wells is a very critical consideration. In many oil and gas well completions, high strength tubulars are required to handle pressures, but the high carbon alloy steels needed for strength are subject to attack by hydrogen in the $\mathrm{H}_{2} \mathrm{~S}$. The effect is an embrittlement of the metal and increased internal stresses which lead to cracking and eventual failure. It has been determined that hardness of Rc 22 is the upper limit for steels in $\mathrm{H}_{2} \mathrm{~S}$ atmospheres, under 
certain temperature conditions. One solution has been to use heavier weights of lower carbon steel to obtain strength. Certain special alloys and heat treating methods can also give stronger pipe with $\mathrm{H}_{2} \mathrm{~S}$ resistance.

Actual $\mathrm{H}_{2} \mathrm{~S}$ concentration in various geopressured sites as reported by Kharaka (1977) vary from too low to detect to as high as $5 \mathrm{ppm}$; most samples average 1-2 ppm. Any $\mathrm{H}_{2} \mathrm{~S}$ concentration should be considered potentially damaging in the presence of hot water, until extensive lab and field tests establish acceptable tolerances for various pipe grades. In injection wells, the addition of oxygen in the presence of even traces of $\mathrm{H}_{2} \mathrm{~S}$ may be highly corrosive. And the sensitivity of steel to chlorides, which definitely exist in the brines, can be a problem.

Perforating. One advantage of large diameter tubing is that larger, more powerful perforating guns can be used. Documentation of gun performance at expected temperature and pressure conditions should be obtained from service companies so that actual perforation diameter will be known.

Perforation plugging by jet charge debris should be removed by special backsurging techniques or underbalanced perforating adapted to long intervals. Or the interval may be acid washed. Plugging in part of the total number of holes may increase flow above critical velocities in the remainder. Clean perforation tunnels are particularly important in inside gravel packing. If gravel is not placed inside the tunnel, fine grained, very low permeability formation sand then can pack the tunnel by bridging against the main gravel pack.

High density completion fluids. At any time in the well's life after the original protective filter cake is removed and drilling mud is displaced from the hole, a fluid of up to $18 \mathrm{ppg}$ density (0.934 psi/ft gradient) must be used to cover the productive zone when downhole work is in progress. There are 
two basic choices to make in completion or workover fluid selection: 1) The fluid can build a second filter cake and remain within the borehole, or 2) It can penetrate the clean borehole wall and the pore spaces of the surrounding sand. There are special applications for each type, as has been discussed.

The non-penetrating type must contain a bridging material and a weighting materal, and neither component can be left in the hole as a deposit that cannot be easily removed. Barites (barium sulfate) commonly used for weight in drilling muds are insoluble solids. So more expensive dense, acid soluble chemicals will have to be used, such as iron carbonate, barium carbonate, ferric oxide and the high density lithium bromide composition (\$300-400 per barrel) mentioned earlier. Calcium carbonate can be used as a bridging material. Large volumes will be needed if long open holes are ever exposed, as in open hole gravel packing. Also, polymers used in drilling and completion fluids have temperature limits that should be defined.

Penetrating fluids should be used with caution as there is presently no economical way to produce a dense fluid that is clean enough to enter fine grained Gulf Coast sands without reducing permeability. It is common practice to use filtered brines that are hopefully compatible with formation clays, and continually replace fluid lost to the formation. Suman (1975) presents data on lab tests in which even $450 \mathrm{md}$ sand suffered $20 \%$ permeability loss after exposure to water cleaned through a 2 -micron filter. Contjnuing work is needed to develop, economical, high density, non-damaging completion fluids for geopressured geothermal applications.

Primary Cementing. The problems of cementing in high temperature holes is becoming well recognized. And it has been recommended that data on existing cement compositions, such as strength retrogression, be extended into geothermal temperature ranges. However, the requirements for primary cementing will be more demanding in geopressured geothermal environments due to the need for long term 
support and protection of the casing installation across the producing zones. This means protecting the pipe from damage by the formation, and equally important, using the casing and cement sheath to support the formation to prevent destabilization and sanding problems.

High density drilling muds will be difficult to displace in deep, small diameter holes around the final liner installations. Turbulent flow of flushing fluids and the cement slurry will likely be impossible to attain in the pipe to formation annulus, without breaking down the formation. And the high temperatures will promote mud thickening while displacement operations are being organized. Thus severe mud contamination and channeling is likely. After the well is perforated, this entrapped mud can be flushed out by production leaving voids behind the pipe.

While development work must progress on the special problem of cementing geopressured wells, the limitations should be recognized now so that operations can be organized to allow best available state of the art techniques to be applied without rig site delays. And complete documentation of the program, execution and testing should be kept to correlate future problems with possible causes. Proper cementing procedures for conventional wells are adequately described in the World Oil Cementing Handbook (Suman and Ellis, 1977). 
Elastomer limitation. The failure of elastomer materials at high temperatures has been discussed repeatedly. And the fact that elastomers fail in high temperature is being proved daily in California steam flooding projects, and in The Geysers drilling operation. The Edna Delcambre 1 test proved that nearly everything made of rubber rated to conventional oil field temperature conditions fạiled.

The basic failure mode for rubber is continued cure hardening with heat which causes the material to lose its elasticity. This process starts at about $250^{\circ} \mathrm{F}$. If the hardened material then is forced to move, the seal is broken. Chevron U.S.A. Inc. tested nearly all available oil field rubbers in flowing steam at $450-475^{\circ} \mathrm{F}$ temperatures and reported that only Ethylene Propylene retained its resiliency--all other rubber materials failed within 48 hours. The other materials included Butyl, Neoprene, Nitrile, Hycar, Styrene Butadiene and Buna S. The Ethylene Propylene will not bond to metal, limiting its use in tool application. Teflon has a higher temperature rating but it loses strength rapidly after $400^{\circ} \mathrm{F}$ and starts to vaporize at about $600^{\circ} \mathrm{F}$. Silicon material stands high temperatures but has no tear resistance. DuPont recently announced a new perfluoroelastomer product called Kalrez, a "rubber Teflon" that was successfully used downhole in The Geysers to protect a logging sonde connection. The product is difficult to compound and fabricate. The action of hot water on rubbers is also different than the effects of hydrocarbons. 011 and gas can cause rubber to swell. However, hot water attacks the rubber molecularly to deteriorate it. Thus, temperature limits should be established under dynamic, working conditions in the presence of actual waters to which the product will be exposed. Geopressured geothermal wells have temperature ranges that will place them either in the upper limits of available materiais or well beyond those limits. Where safety is concerned, as it will be, 
those limits should be firmly established. The alternatives in completion design are: 1) Incorporate metal to metal seals in all possible locations, 2) Avoid downhole use of rubber or Teflon type dynamic seals in permanent applications, 3) Use rubber seals downhole only when circulating fluids cool the hole, and 4) Consider all hot water environments above $250^{\circ} \mathrm{F}$ to be limiting to elastomer use.

Well control. Safety cannot be overemphasized. The petroleum industry has no experience in handling blowouts in geopressured geothermal wells where explosive methane gas is involved, but it is obvious that the consequences must be avoided. In offshore oil and gas wells, federal law requires use of downhole safety valves that automatically close when dangerous conditions are detected. These valves are located in the tubing string and all flow passes through them. Velocity types have a built in resistance that becomes self energizing when flow is excessive. Others are closed by hydraulic pressure from surface; these require a separate hydraulic line.

Geothermal wells with large diameter tubing will present special problems regarding subsurface safety valves, should their use ever be mandated. Large diameter valves are being used in North Sea wells already in $51 / 2 \div 7$ inch tubing. These valves would be a severe restriction in the wide-open bore, that would increase friction. But, more importantly, they would create an eddy that could initiate rapid scale buildup. And the hydraulic line would be added equipment to maintain in the high temperature environment - Velocity/ type valves would not be suitable where flow is already near maximum. Despite the problems, work should proceed on development of subsurface safety valves, or some other type of emergency downhole shutoff, that is applicable to these specialized completions.

The present solution is to install operators on the surface valves that will 
automatically shut in the well when signalled. It is common practice to : maintain such hydraulic or pneumatic operators in a "fail closed" mode, i.e. pressure is applied to hold the valve open. If pressure is lost, as in a fire or other accident, strong springs automatically force the valve closed. 


\section{REFERENCES}

1. Altseimer, J. H., "Geothermal Well Technology and Potential Applications of Subterrene Devices - A Status Review", Proceedings Second UN Symposium on Development and Use of Geothermal Resources", San Francisco, May 20-29, 1975, Vol. III, pp. 1399-1410.

2. Austin, C. F., Austin, W. H. Jr. and Leonard, G. W., Geothermal Science and Technology, a National Program, Technical Series 45-029-72, Naval Weapons Center, China Lake, CA., Sept. 1971.

3. Blair, A. G., Tester, J.,W. and Mortensen, J. J.., LASL Hot Dry Rock Geothermal Project, July 1,1975 - June 30,1976 , Progress Report LA-6525-PR, LOS, Alamos Scientific Laboratory, New Mexico.

4. Boyd, W. E. Completion Techniques for Geothermal - Geopressured Wells, Report for ERDA Contract E (40-1) - 5243, Center for Energy Studies, Univ. of Texas, 1977.

5. Butler, D. R., "Geothermal Energy on the Pacific Coast", Publication by Chevron 0ii Co. Minerals Staff, San Francisco, 1975.

6. Chasteen, A. J., "Geothermal Steam Condensate Reinjection", UN Symp. (see Ref. 1), Vol. 2, pp. 1335-1337.

7. Cigni, U., Fabbri, F and Giovanncni, A., Advancement in Cementation Techniques in the Italian Geothermai Wells", UN Symp. (See Ref. 1), Vo1. III, pp. 1471-1487.

8. Cromling, J., "How Geothermal Wells Are Drilled and Completed", World 0i1, Dec. 1973, pp. $42-45$.

9. Fertl, W. H. and Timko, D. J., How Downhole Temperatures, Pressures Affect Drilling, 10 part series reprinted from World 0il, Gulf Publishing Co., Houston, 1973.

10. Finney:; J. P., Miller, F. J. and Mills, D...B., "Geothermal Power Project of Pacific Gas and Electric Co. at the Geysers .California", IEEE Power Engineering Socjety Sumer Meeting, July 1972.

11. Jones, P. H. "Geothermal and Hydrocarbon Regimes, Northern Gulf of Mexico Basin", Proceedings of First Geopressured Geothermal Energy Conference, Center for Energy Studies, Univ. of Texas, June 2-4, 1975.

12. Kharaka, Y. R. Callender, E., and Wallace, R. H. Jr., "Geochemistry of Geopressured Geothermal Waters From the Frio Clay in the Gulf Goast Region of Texas", Geology, Vol. 5, April 1977., pp. 241-244.

13. Kruger, P. and Otte, C., Editors, Geothermal Energy Resources, Production, Stimulation, Stanford University Press, Stanford, CA, 346 pages, 1973 . . 
14. Lombard, G. L., "San Diego Gas and Electric Company's Pioneering Geothermal Test Work in the Imperial Valley of Southern Callfornia, USA," UN Symp. (s.ee Ref. 1) pp. 2037-2045.

15. Mathias, K., "The Mesa Geothermal Field - a Preliminary Evaluation of Five Geothermal Wells." UN Symp. (see Ref, 1). Vol. III, pp. 1741-1748

16. Mauer, W. C., "Geothermal Drilling Technology, "UN Symp. (see Ref. 1). Vo1. III, Pp. 1509-1522.

17. McGetchin, T.R. et a1, Hot Dry Rock Geothermal Energy: Status of Exploration and Assessment, Report No. 1 of the HDR Assessment Pane], La-UR 77-T157, Los Alamos Scientific Laboratory, New Mexico.

18. Peters, S., "Civil Engineering: Fea tures of a Geotherma 1 Power Plant". ASCE National Meeting on Hater Resources, Los Angeles, Jan. 21-25, 1974.

19. Reed, M.I.J. and Campbe11, G. E. . Environmental Impact of Development in The Geysers Geotherma ifjeld, USA", UN Symp. (See Ref. 1), Vo1. III, pp. 1399-1410. $+11,+3$

20. Robinson, J., "Environmental Constraints on Geothermal Development", Paper SPE 5384, 45th Annual California Regional Mtg. of SPE of AIME, Ventura, Apri1 2-4, 1975.

21. Snyder, R. E., "How Steam is Produced and Handled at The Geysers", World 0il, June 1975, pp. 43-48.

22. Stuart, C. A., Geopressures, Proceedings of Second Symposium on Abnormal Subsurface Pressure, Louisiana State Unjuersity, Jan. 30, 1970.

23. Suman, G. 0., Jr., World Oils'Sand Control Handbook, Gulf Publishing Co., 7 Hous ton, 1975.

24. Suman, G. O. Jr, and EIlis, R. C., World Oil's Cementing Handbook, Including Casing Handling Procedures, Gulf Publishing Co., Houston, 1977.

25. Tester, J. W., Holley,., C. E., Jr., and Blatz, L. A., "Solution Chemistry and Sealing in Hot Dry Rock Geothermal Systems," presented at the AICHE 83rd National Mtg., Houston, Mar. 21-25, 1977.

26. API Spec. 5A, Casing, Jubing, and Drill Pipe, 33rd Edition, Mar. 1976.

27. API Spec. 6A, Wellhead Equipment, 11th Edition, Oct. 1977.

28. API BUL 5C2, Performance Properties of Casing. Tubing, and Drill Pipe, 16th Edition, Mar. 1975.

29. Geothermal Resource Investigations, East Mesa Test Site, Imperial Valley, California, Status Report, United States Dept. of the Interior, Bureau of Reclamation, Apri1 1977. 